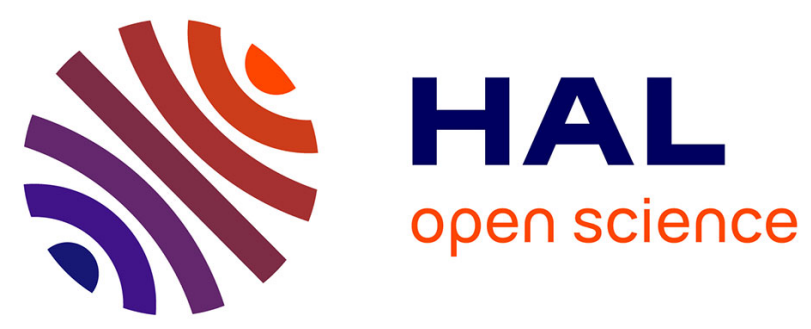

\title{
DIAZABICYCLOOCTANE FUNCTIONALIZATION FOR INHIBITION OF -LACTAMASES FROM ENTEROBACTERIA
}

\author{
Flavie Bouchet, Heiner Atze, Matthieu Fonvielle, Zainab Edoo, Michel
} Arthur, Mélanie Ethève-Quelquejeu, Laura Iannazzo

\section{To cite this version:}

Flavie Bouchet, Heiner Atze, Matthieu Fonvielle, Zainab Edoo, Michel Arthur, et al.. DIAZABICYCLOOCTANE FUNCTIONALIZATION FOR INHIBITION OF -LACTAMASES FROM ENTEROBACTERIA. Journal of Medicinal Chemistry, In press, 10.1021/acs.jmedchem.9b02125 . hal02565751

\section{HAL Id: hal-02565751 \\ https://hal.science/hal-02565751}

Submitted on 6 May 2020

HAL is a multi-disciplinary open access archive for the deposit and dissemination of scientific research documents, whether they are published or not. The documents may come from teaching and research institutions in France or abroad, or from public or private research centers.
L'archive ouverte pluridisciplinaire HAL, est destinée au dépôt et à la diffusion de documents scientifiques de niveau recherche, publiés ou non, émanant des établissements d'enseignement et de recherche français ou étrangers, des laboratoires publics ou privés. 


\title{
DIAZABICYCLOOCTANE FUNCTIONALIZATION FOR INHIBITION $\quad$ OF $\quad \beta$-LACTAMASES $\quad$ FROM
} ENTEROBACTERIA

\author{
Flavie Bouchet,$^{\dagger 1}$ Heiner Atze,,$^{+1}$ Matthieu Fonvielle,,+ Zainab Edoo, ${ }^{+}$Michel Arthur, ${ }^{+*}$ \\ Mélanie Ethève-Quelquejeu, ${ }^{\dagger *}$ Laura Iannazzo ${ }^{\dagger *}$
}

${ }^{\dagger}$ Laboratoire de Chimie et de Biochimie Pharmacologiques et Toxicologiques, Université de Paris, UMR 8601, Paris, F-75006 France; CNRS UMR 8601, Paris, F-75006, France.

INSERM, Sorbonne Université, Université de Paris, Centre de Recherche des Cordeliers, F75006, Paris, France.

\begin{abstract}
Second-generation $\beta$-lactamase inhibitors containing a diazabicyclooctane (DBO) scaffold restore the activity of $\beta$-lactams against pathogenic bacteria, including those producing class $\mathrm{A}, \mathrm{C}$, and $\mathrm{D}$ enzymes that are not susceptible to first-generation inhibitors containing a $\beta$-lactam ring. Here, we report optimization of a synthetic route to access triazolecontaining DBOs and biological evaluation of a series of 17 compounds for inhibition of five $\beta$-lactamases representative of enzymes found in pathogenic Gram-negative bacteria. A strong correlation (Spearman coefficient of $0.87 ; p=4.710^{-21}$ ) was observed between the inhibition efficacy of purified $\beta$-lactamases and the potentiation of $\beta$-lactam antibacterial activity indicating that DBO functionalization did not impair penetration. In comparison to reference DBOs, avibactam and relebactam, our compounds displayed reduced efficacy likely due to the absence of hydrogen bonding with a conserved asparagine residue at position 132. This was partially compensated by additional interactions involving certain triazole substituents.
\end{abstract}




\section{INTRODUCTION}

Penicillin is the first broadly used antibiotic introduced in medicine and the $\beta$-lactams remain the most widely used drug family in spite of the emergence of various resistance mechanisms. ${ }^{1}$ The targets of $\beta$-lactams are the D,D-transpeptidases, commonly referred to as penicillinbinding proteins (PBPs), that catalyze the last cross-linking step of peptidoglycan synthesis. ${ }^{2}$ The most common $\beta$-lactam resistance mechanism in Gram-negative bacteria is the production of one or more $\beta$-lactamases, which catalyze the hydrolysis of the amide bond of the fourmembered $\beta$-lactam ring (Figure 1A). ${ }^{3}$ The hydrolysis product is not active accounting for the absence of inhibition of the PBP targets. This resistance mechanism has been successfully defeated by $\beta$-lactamase inhibitors, clavulanate, sulbactam, and tazobactam (Figure 1B). ${ }^{3,4}$ In the presence of these inhibitors, the drug (imipenem in Figure 1C) remains active for acylation of the PBPs. First-generation inhibitors contain a $\beta$-lactam ring and act as suicide substrates forming stable adducts with $\beta$-lactamases (Figure 1C). ${ }^{3}$ Avibactam (Figure 1B), clinically approved in combination with ceftazidime in 2015 , is the first representative of secondgeneration inhibitors. Its structure is based on a distinct scaffold, diazabicyclooctane (DBO), which contains a five-membered cyclic urea rather than a $\beta$-lactam ring. ${ }^{5,6}$ The mechanism of action of avibactam relies on nucleophilic attack of the DBO carbonyl by the active serine of class A, C and D $\beta$-lactamase leading to regioselective opening of the cyclic urea and nitrogen protonation (Figure 1D). ${ }^{6}$ This reaction affords a stable carbamoyl-enzyme adduct. In contrast to $\beta$-lactam-containing inhibitors, formation of the carbamoyl-enzyme is fully reversible regenerating native $\beta$-lactamase and avibactam. ${ }^{6-8}$ The efficacy of avibactam relies on the stabilization of the adduct that displaces the equilibrium toward the covalent carbamoylenzyme. Stabilization is also important to prevent carbamoyl-enzyme hydrolysis, which proceeds through an initial desulfonation for certain $\beta$-lactamases. ${ }^{9-11}$ Compared to the firstgeneration inhibitors, avibactam inhibits a wider range of $\beta$-lactamases (class $\mathrm{A}, \mathrm{C}$, and some 
class D enzymes). ${ }^{3}$ In particular, avibactam inhibits $\beta$-lactamases that are fully insensitive to inhibition by clavulanate, such as Klebsiella pneumoniae carbapenemases (KPC) and Mycobacterium abscessus Bla $\mathrm{a}_{\mathrm{ab}}$. Avibactam does not effectively inhibit zinc-dependent metallo- $\beta$-lactamases (class B enzymes ) since it binds only weakly to most tested enzymes and it is slowly hydrolyzed in certain cases. ${ }^{12,13}$ In parallel to DBOs, unrelated $\beta$-lactamase inhibitors based on a cyclic boronic acid pharmacophore are currently developed, including vaborbactam, ${ }^{14,15}$ recently approved by the FDA in combination with meropenem. ${ }^{16,17}$ Discovery of additional $\beta$-lactamase inhibitors, including DBOs and boronates, is needed to broaden inhibition spectra, in particular to include inhibition of class B and D enzymes. In addition, mutations in $\beta$-lactamase genes have emerged in vitro and under treatment by the ceftazidime-avibactam combination. ${ }^{18-21}$ Interestingly, the potency of vaborbactam was reported to be less affected than that of avibactam in strains producing KPC-2 carbapenemase variants that confer resistance to the ceftazidime-avibactam combination. ${ }^{17,22}$

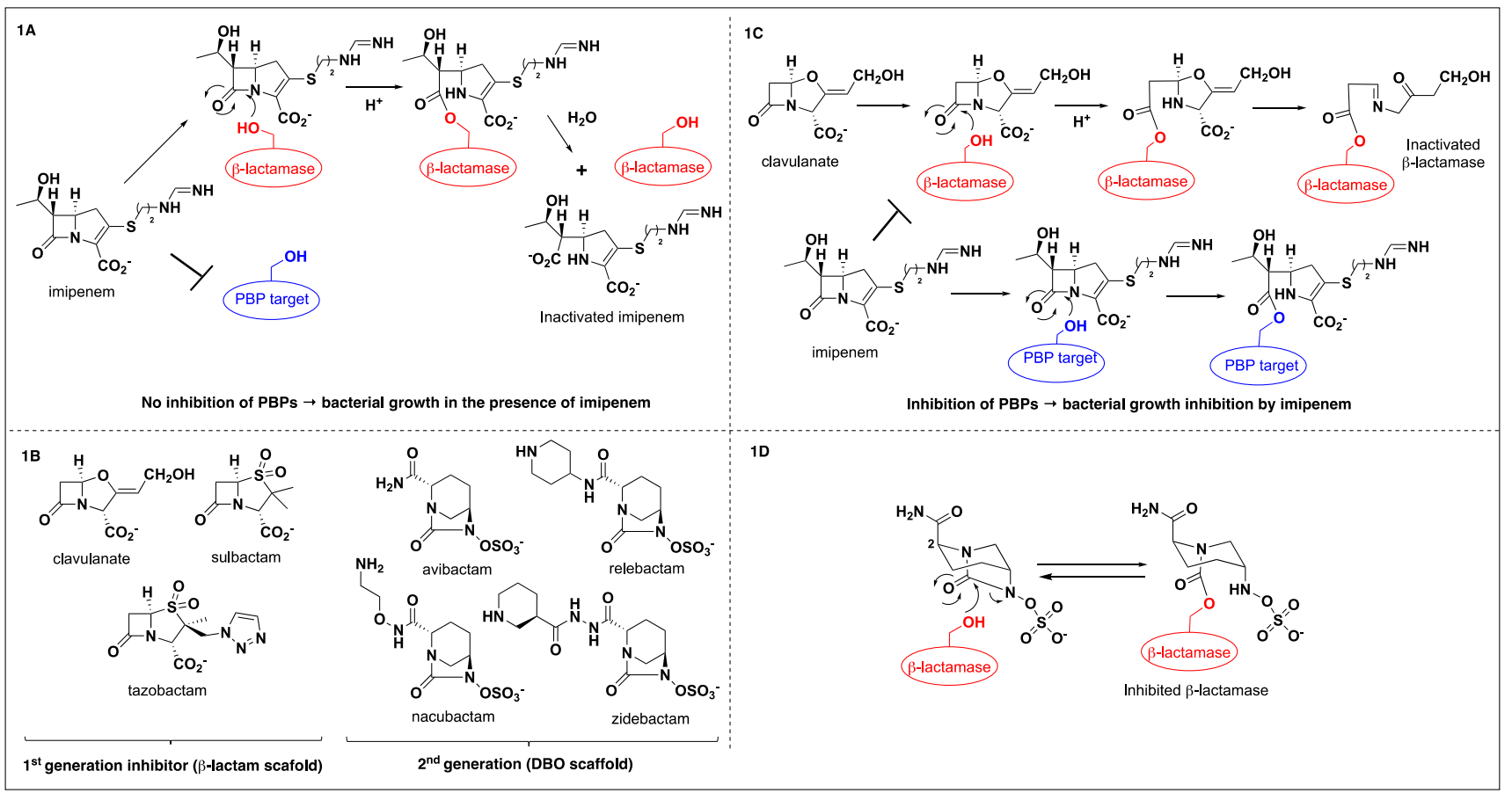

Figure 1. Structure and mode of action of antibiotics and $\beta$-lactamase inhibitors. (1A) $\beta$ lactamase-mediated resistance to imipenem. (1B) Structure of $1^{\text {st }}$ and $2^{\text {nd }}$ generation $\beta$ - 
lactamase inhibitors based on $\beta$-lactam and diazabicyclooctane (DBO) scaffolds, respectively. (1C) Mode of action of a $\beta$-lactamase inhibitor (clavulanate), which prevents imipenem hydrolysis enabling inactivation of the penicillin-binding protein (PBP) targets. (1D) Avibactam-mediated $\beta$-lactamase inhibition by reversible formation of a carbamoyl-enzyme.

Functionalization of the DBO scaffold has been extensively explored to improve their $\beta$ lactamase inhibition spectra. ${ }^{23-31}$ In addition, introduction of side chains was reported to afford dual inhibitors that act both on $\beta$-lactamases and on essential penicillin-binding proteins required for cell wall peptidoglycan polymerization. ${ }^{23}$ Since DBOs are chemically challenging molecules in terms of their structures, we recently developed a versatile method using coppercatalyzed alkyne-azide cycloaddition (CuAAC) to introduce 1,2,3-triazole-containing substituents at the $\mathrm{C}_{2}$ position of the DBO scaffold. ${ }^{32}$ Here, we report modification of our synthetic scheme (Scheme 1), which enabled synthesis of a series of compounds in sufficient amount for biological evaluation of a panel of five representatives of class A, C, and D $\beta$ lactamases. This evaluation involved both the determination of kinetic parameters for $\beta$ lactamase inhibition and evaluation of antibacterial activity against isogenic strains producing specific $\beta$-lactamases.

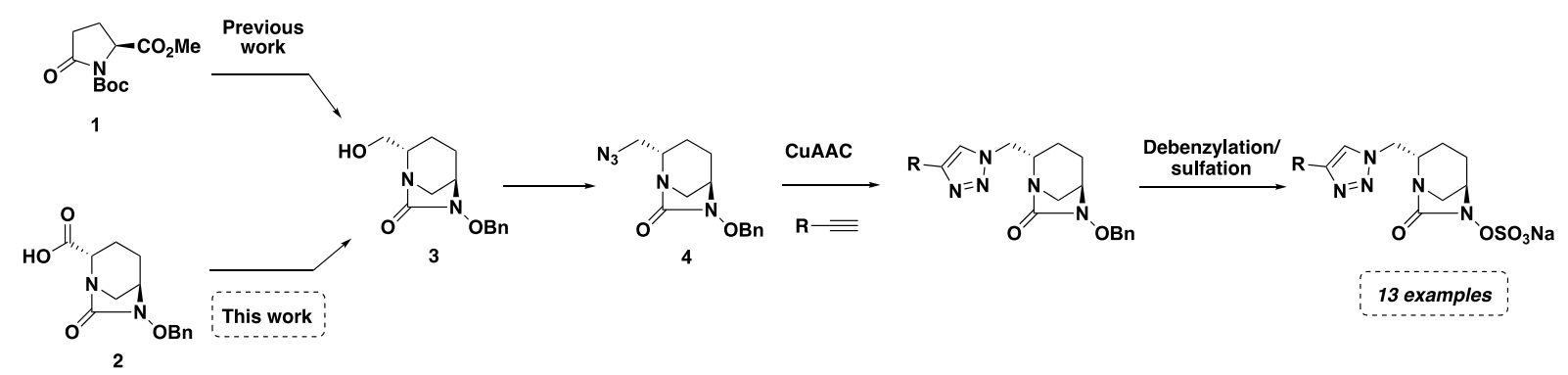

Scheme 1. Strategies to access functionalized DBOs

\section{RESULTS AND DISSCUSSION}

Chemical synthesis. We recently reported the synthesis of 2-azido-diazabicyclooctane 4 starting from commercially available protected oxopyrrolidine $\mathbf{1}$ (Scheme 1$){ }^{32}$ This procedure 
proceeds through the synthesis of the alcohol intermediate $\mathbf{3}$ and provides access to the key azido-intermediate 4 for the copper(I)-catalyzed Huisgen-Sharpless cycloaddition reaction ${ }^{33}$ with an overall yield of $4 \%$. Here, we propose a modification of our approach starting with the carboxylic acid DBO derivative $\mathbf{2}$, which has recently been made commercially available. DBO 2 was activated with iso-butylchloroformate and directly reduced with $\mathrm{NaBH}_{4}$ to afford the corresponding alcohol 3 (Scheme 1). By a classical strategy, the activation of $\mathbf{3}$ with mesylchloride followed by a nucleophilic substitution in the presence of sodium azide provided azido derivative 4 .

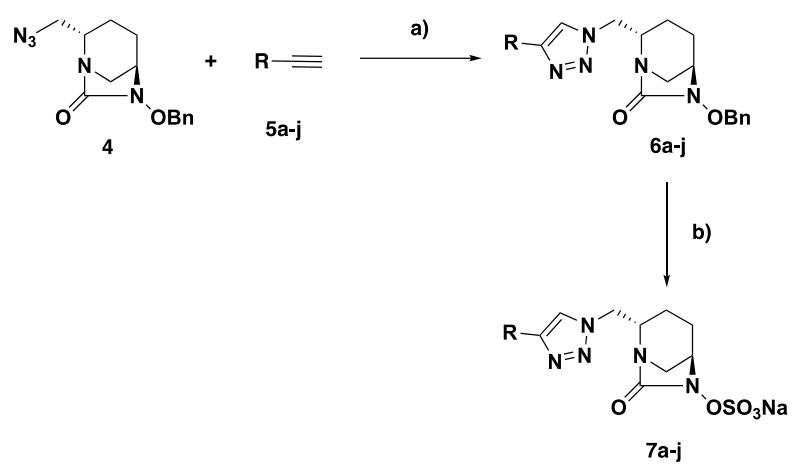

Scheme 2. a) $\mathrm{CuSO}_{4} 30 \mathrm{~mol} \%$, sodium ascorbate $60 \mathrm{~mol} \%$, THF/ $\mathrm{H}_{2} \mathrm{O}(3 / 1)$, rt, overnight; b) i. $\mathrm{Pd} / \mathrm{C}, \mathrm{H}_{2}, \mathrm{MeOH}, \mathrm{rt}, 48$ h, ii. $\mathrm{SO}_{3}-\mathrm{Pyr}$, pyridine, rt, overnight, iii. DOWEX $\mathrm{Na}^{+}$.

The functionalization of $\mathbf{4}$ was then explored with various alkynes to afford a series of new DBOs (Table 1). The rationale behind the study was to validate the synthetic approach for substituents containing various functional groups. Briefly, alkynes $\mathbf{5 a}, \mathbf{5 b}, \mathbf{5 c}, \mathbf{5 d}, \mathbf{5 e}, \mathbf{5 h}$, and $\mathbf{5 j}$ were commercially available whereas $\mathbf{5 f}, \mathbf{5 g}$, and $\mathbf{5 i}$ were prepared according to standard procedures (See supporting information). Compound $\mathbf{4}$ and alkynes $\mathbf{5 a - j}$ were subjected to $\mathrm{CuAAC}$ conditions using $\mathrm{CuSO}_{4}(30 \mathrm{~mol} \%)$ and sodium ascorbate $(60 \mathrm{~mol} \%)$ in $\mathrm{THF} / \mathrm{H}_{2} \mathrm{O}$ overnight at room temperature to afford compounds 6a-j in 30 to $97 \%$ yield (Scheme 2). A wide range of alkynes was compatible with this procedure including compounds containing aromatic rings, such as pyridine (5a) and phenyl $(\mathbf{5 b}, \mathbf{5 i}), \mathrm{Si}, \mathrm{O}$, or $\mathrm{N}$ heteroatoms $(\mathbf{5 c - f})$, a 
protected amine (5g-i), or a carboxylic acid function $(\mathbf{5 j})$. The deprotection of the benzyl group of compounds 6a-j was performed by hydrogenolysis followed by sulfation with sulfur trioxide pyridine complex. The purification of the final compounds $7 \mathbf{a}-\mathbf{j}$ has been optimized by elution through DOWEX Na${ }^{+}$followed by the dissolution of the residue in ethanol and filtration. This additional step was helpful for an efficient purification of DBOs over HPLC and allowed increasing the overall sulfation yield (from $10 \%$ for compounds $7 \mathbf{a}$ and $7 \mathbf{c}$ according to the previous method ${ }^{32}$ to $21 \%$ and $14 \%$, respectively, in the current study). The final deprotection step for Boc-containing DBOs $(\mathbf{7 g}, \mathbf{7 h}$, and $\mathbf{7 i})$ was performed by treatment with TFA in DCM at $0^{\circ} \mathrm{C}$ for $1 \mathrm{~h}$ (Scheme 3). Unprotected DBOs $\mathbf{8 g}, \mathbf{8 h}$, and $\mathbf{8 i}$ were isolated in 36, 34 and 17\% yield after HPLC purification, respectively.

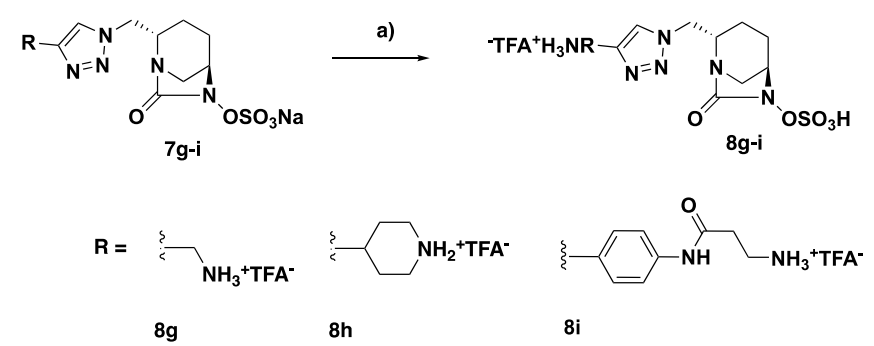

Scheme 3. a) TFA, DCM, $0^{\circ} \mathrm{C}, 1$ h; $8 \mathrm{~g}(36 \%) ; 8 \mathbf{h}(34 \%) ; \mathbf{8 i}(17 \%)$.

To get access to unsubstituted triazoles 10a and 10b (Scheme 4), a new strategy has been designed. The alcohol 3 was activated with mesylchloride and treated with 1H-1,2,3-triazole under basic conditions ${ }^{34}$ to afford regioisomers $9 \mathbf{a}$ and $\mathbf{9 b}$ in 44 and 37\% yield, respectively. After separation of the two regioisomers by chromatography, each compound was submitted to hydrogenolysis conditions to remove the benzyl group followed by the sulfation step and elution on DOWEX $\mathrm{Na}^{+}$, as described above. 


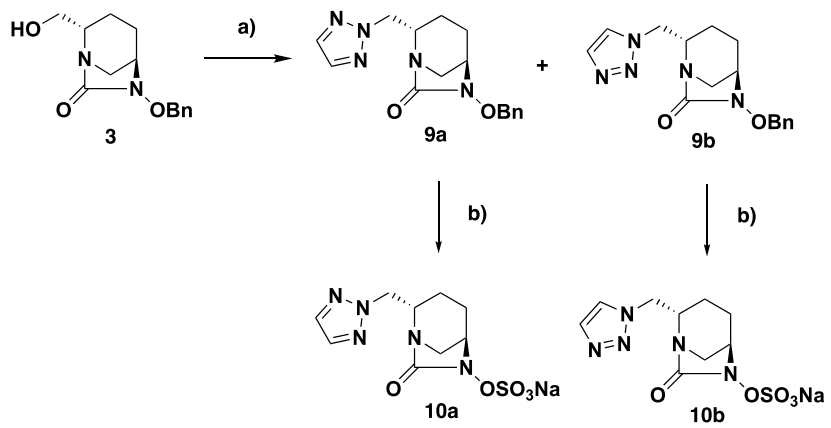

Scheme 4. a) i. $\mathrm{MsCl}, \mathrm{NEt}_{3}, \mathrm{DMAP}, \mathrm{DCM}, 0^{\circ} \mathrm{C}, 1 \mathrm{~h}$, ii. $1 \mathrm{H}-1,2,3$-triazole, $\mathrm{tBuOK}, \mathrm{MeCN}$, reflux, 15h; 9a (44\%); 9b (37\%); b) i. $\mathrm{Pd} / \mathrm{C}, \mathrm{H}_{2}, \mathrm{MeOH}$, rt, 48h, ii. $\mathrm{SO}_{3}-\mathrm{Pyr}$, pyridine, rt, overnight, iii. DOWEX Na ${ }^{+} ; \mathbf{1 0 a}(27 \%) ; 10 b(8 \%)$.

Table 1. Structure of alkynes used for CuAAC, resulting triazole-containing DBOs, and final sulfated compounds

(n)




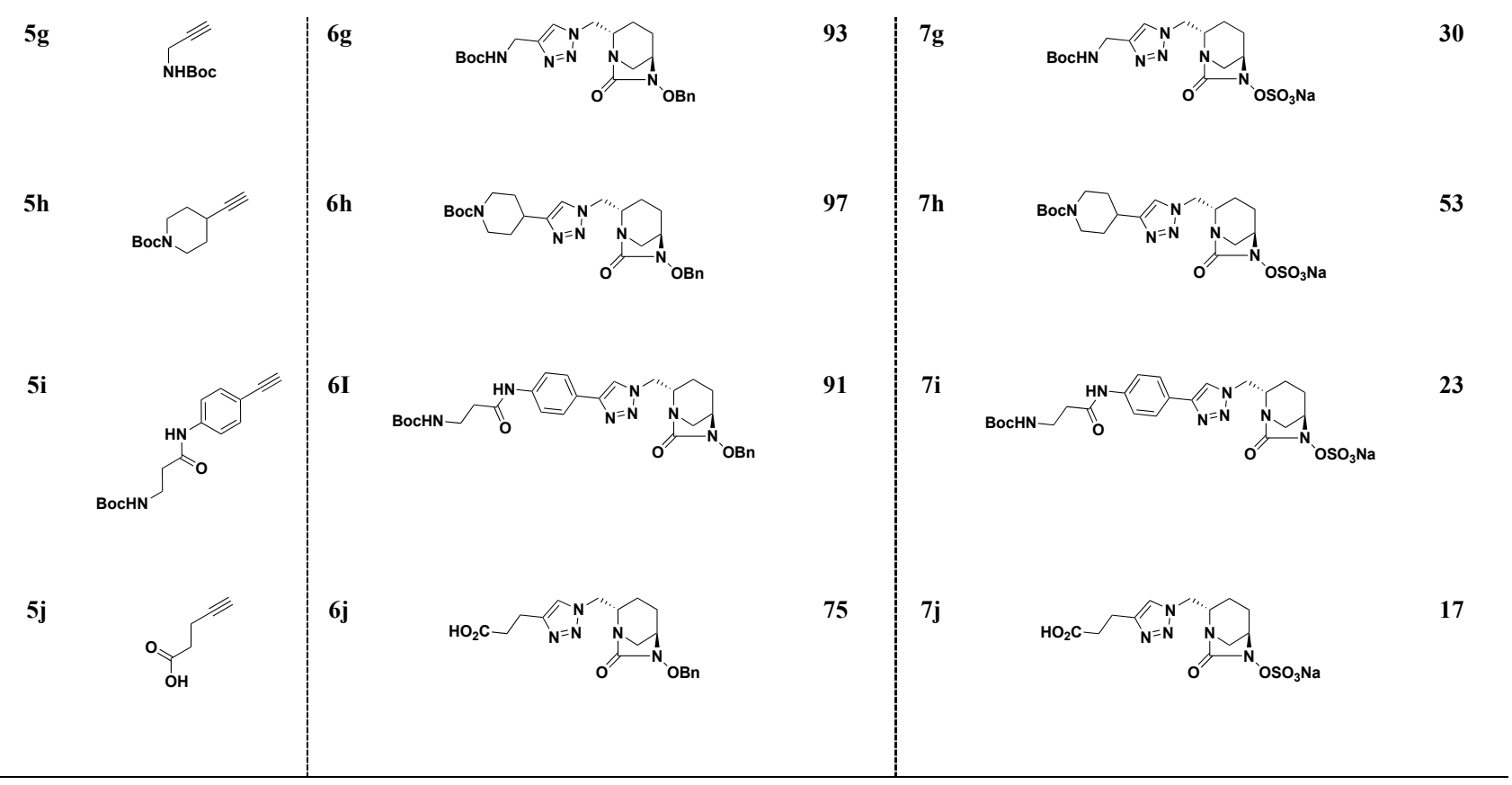

Rationale for cell-based assays of DBOs. We chose a panel of five $\beta$-lactamases that are clinically relevant, belong to different structural classes, and differ by their hydrolysis spectrum. ${ }^{3}$ KPC-2 (class A) and OXA-48 (class D) hydrolyze carbapenems (carbapenemases), which are often the last resort antibiotics against multi-drug-resistant bacteria. CTX-M-15 and AmpC from Enterobacter cloacae were chosen as representatives of class A extended-spectrum $\beta$-lactamases and of class $\mathrm{C}$ cephalosporinases (preferential hydrolysis of cephems). TEM-1 is a wide-spread representative of penicillinases (preferential hydrolysis of penams). Genes encoding these five $\beta$-lactamases were cloned under the control of an inducible promoter into the vector pTR99k and introduced in Escherichia coli Top10. The efficacy of the DBOs was tested by determining the minimal inhibitory concentration (MIC) of $\beta$-lactams in the presence or absence of a fixed concentration of inhibitor (15 $\mu \mathrm{M}$ corresponding to $4 \mu \mathrm{g} / \mathrm{ml}$ for avibactam). Since the TEM-1, KPC-2, CTX-M-15, AmpC, and OXA-48 $\beta$-lactamases display different substrate spectra, preliminary experiments were performed to choose a suitable antibiotic to compare the efficacy of the inhibitors (Figure 2). 

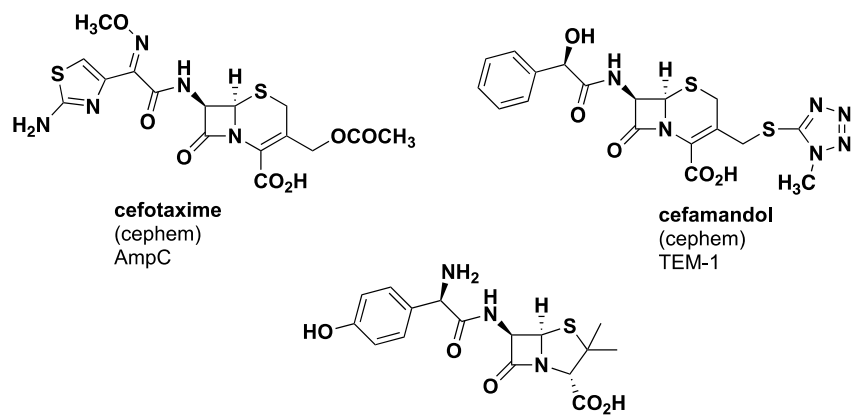
(cephem)

\section{amoxicillin} (penam)
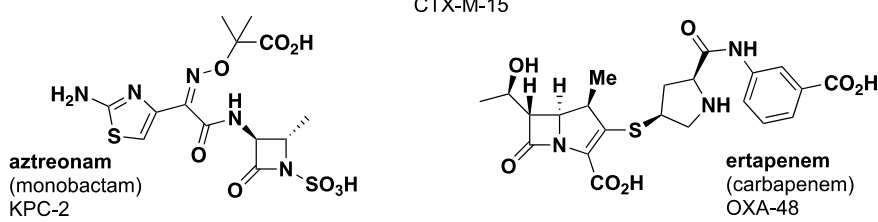

Figure 2. Structure of $\beta$-lactam antibiotics used as substrates to determine the activity of $\beta$ lactamases TEM-1, KPC-2, CTX-M-15, AmpC, and OXA-48. The drugs belong to the cephem, monobactam, penam, or carbapenem classes of $\beta$-lactams, as indicated in parenthesis.

For each of the five chosen $\beta$-lactam/ $\beta$-lactamase combinations, $\beta$-lactamase production led to large MIC increases, ranging from 256 to 4,096 fold. For the cefamandole/TEM-1 combination for example, production of TEM-1 in the E. coli Top10 host resulted in a 1,024-fold increase in the MIC of cefamandole (from 2 to 2,048 $\mu \mathrm{g} / \mathrm{ml}$ ) (Table 2). Such a high dynamic range offers the possibility to compare inhibitors with various efficacies leading to partial inhibition of the $\beta$-lactamases and various MICs in the 2 to $2,048 \mu \mathrm{g} / \mathrm{ml}$ range. Complete in vivo inhibition of TEM-1 requires very efficacious DBOs able to lead to the 1,024-fold decrease in the MIC needed to restore full susceptibility. For such inhibitors, the MICs of cefamandole against $E$. coli TOP10 and its isogenic TEM-producing derivative should be the same $(2 \mu \mathrm{g} / \mathrm{ml})$. For TEM-1 and cefamandole, this is the case for the first-generation inhibitor clavulanate (Table 2).

Table 2. Inhibition of penicillinase TEM-1 by DBOs and clavulanate

\begin{tabular}{|c|c|c|c|}
\hline 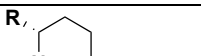 & Carbamoylation & MIC of $\mathrm{c}$ & $(\mu \mathrm{g} / \mathrm{ml})$ \\
\hline$\overbrace{0}^{\mathrm{N}}=\mathrm{N}_{\mathrm{OSO}_{3} \mathrm{Na}}$ & $\begin{array}{l}\text { efficacy } \\
\left(\mathrm{M}^{-1} \mathrm{~s}^{-1}\right)\end{array}$ & $\begin{array}{l}\text { Without } \\
\text { TEM-1 }\end{array}$ & $\begin{array}{l}\text { With } \\
\text { TEM-1 }\end{array}$ \\
\hline
\end{tabular}


$\mathbf{R}=$

\begin{tabular}{|c|c|c|c|c|}
\hline \multirow[t]{2}{*}{ no inhibitor } & & NA & 2 & 2,048 \\
\hline & Avibactam & $88,000 \pm 2,000$ & 2 & 2 \\
\hline & Relebactam & $43,000 \pm 1,000$ & 2 & 4 \\
\hline & $7 a$ & $1,400 \pm 100$ & 2 & 8 \\
\hline & $7 b$ & $4,700 \pm 1,000$ & 4 & 16 \\
\hline & $7 \mathrm{c}$ & $370 \pm 50$ & 2 & 64 \\
\hline & $7 \mathrm{~d}$ & $830 \pm 50$ & 2 & 16 \\
\hline & $7 \mathrm{e}$ & $780 \pm 80$ & 2 & 32 \\
\hline & $7 f$ & $1,200 \pm 100$ & 2 & 8 \\
\hline & $7 \mathrm{~g}$ & $2,800 \pm 400$ & 2 & 128 \\
\hline & $7 \mathrm{~h}$ & $1,700 \pm 200$ & 2 & 256 \\
\hline & $7 i$ & $3,700 \pm 500$ & 2 & 256 \\
\hline & $8 \mathrm{~g}$ & $3,100 \pm 200$ & 4 & 4 \\
\hline & $8 \mathrm{~h}$ & $3,600 \pm 300$ & 2 & 4 \\
\hline & $8 \mathrm{i}$ & $940 \pm 150$ & 2 & 32 \\
\hline & $7 \mathrm{j}$ & $720 \pm 60$ & 2 & 32 \\
\hline & $10 \mathrm{a}$ & $2,600 \pm 300$ & 2 & 16 \\
\hline & $10 \mathrm{~b}$ & $1,200 \pm 100$ & 2 & 8 \\
\hline & Clavulanate & NA & 2 & 2 \\
\hline
\end{tabular}

NA, not applicable as clavulanate and DBOs have different modes of action. Kinetics constants were deduced from a minimum of six progress curves obtained in a minimum of two independent experiments. Reported MICs are the medians from five biological repeats obtained in two independent experiments. ${ }^{[a]}$ Zwitterionic species have been tested. ${ }^{[b]}$ Avibactam alone was moderately active (MIC $=32 \mu \mathrm{g} / \mathrm{ml})$ against $E$. coli Top10 harboring the vector pTRC-99k but none of our DBOs displayed activity in the absence of $\beta$-lactam (MIC $>128 \mu \mathrm{g} / \mathrm{ml}$ ). 
Rationale for enzymatic inhibition assays of DBOs. Genes encoding soluble fragments of TEM-1, KPC-2, CTX-M-15, AmpC, and OXA-48 were cloned into the pET-TEV vector. $\beta$ lactamases were produced in E. coli BL21 and purified from clarified lysates by metal affinity and size-exclusion chromatography. For in vitro evaluation of inhibition efficacy, purified $\beta$ lactamases were incubated with DBOs at various concentrations with a fixed concentration of the chromogenic cephalosporin nitrocefin (Figure 3 ). ${ }^{7}$ Estimates of the inhibition efficacy were provided by the ratio of the kinetic constants $k_{2}$ and $K_{\mathrm{i}}$, which takes into account the first order constant $k_{2}$ for the chemical step of the reaction (carbamoylation) and the dissociation constant $K_{\mathrm{i}}$ for the preceding formation of a non-covalent complex. Since $k_{2}$ and $K_{\mathrm{i}}$ could not be independently determined the changes in efficacy might arise from either or both tighter binding and placement of the groups in a more reactive conformation in the active site.

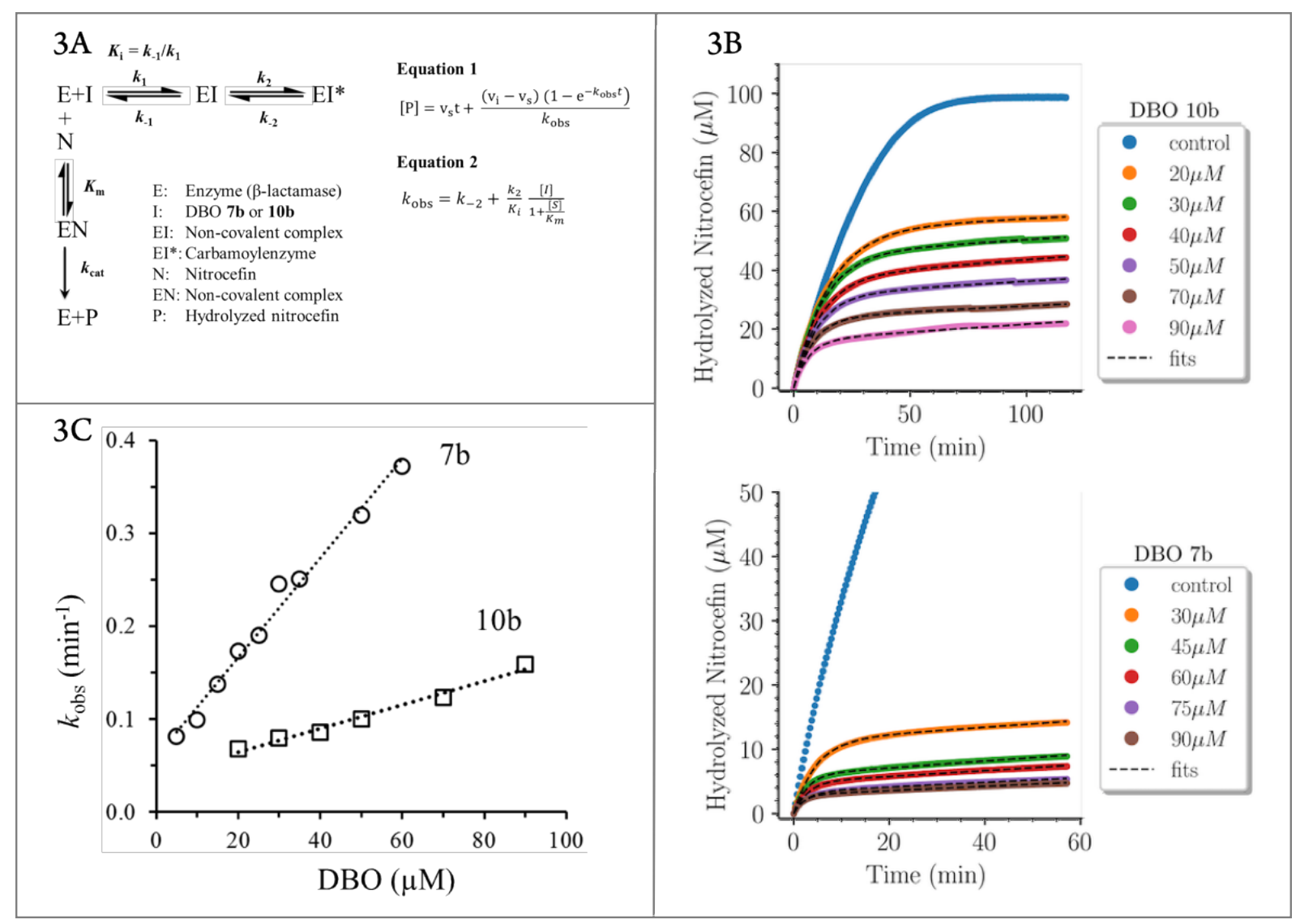


Figure 3. Inhibition of $\beta$-lactamases by DBOs. (A) Reaction scheme and definition of rate constants. $v_{i}$ and $v_{s}$ are the initial and final velocities of the reactions. (B) Time-dependent inhibition of KPC-2 by $\mathbf{7 b}$ and $\mathbf{1 0 b}$ KPC-2 $(2.5 \mathrm{nM})$ was incubated with nitrocefin $(100 \mu \mathrm{M})$ and various concentrations of $\mathbf{7 b}$ and $\mathbf{1 0 b}(20-90 \mu \mathrm{M}$ or $30-90 \mu \mathrm{M}$, respectively). Equation 1 was fitted to progress curves to obtain the pseudo-first order rate constant $k_{\text {obs. }}$ Representative results from one experiment are shown. (C) Determination of carbamoylation rate constant $k_{2} / K_{\mathrm{i}} . k_{\mathrm{obs}}$ was plotted as a function of the DBO concentration. Equation 2 was fitted to data to determine the value of the $k_{2} / K_{\mathrm{i}}$ ratio and of $k_{-2}$. Kinetic constant $k_{-2}$ was low for all DBOs (See supplementary Table S1). Kinetics constants were deduced from a minimum of six progress curves obtained in a minimum of two independent experiments.

Efficacy of inhibition of penicillinase TEM-1 by DBOs. The two reference DBOs, avibactam and relebactam, afforded 1,024- and 512-fold reductions in the MIC of cefamandole indicating that inhibition of TEM-1 was complete or nearly complete, respectively. Our synthetic DBOs offered the possibility to investigate the impact of aromatic rings, carboxylic acids, amines, and the corresponding Boc-protected compounds on the efficacy of DBOs. Two amine-containing compounds, $\mathbf{8 g}$ and $\mathbf{8 h}$, were as active as relebactam, also producing a 512-fold reduction in the MIC of cefamandole. A 256-fold reduction was observed for compounds 7a and 7f, which contain a pyridine or a morpholine group in their side chain, respectively. The in vivo efficacy of the remaining compounds was lower, in particular that of Boc-protected compounds $\mathbf{7 g}, \mathbf{7 h}$, and 7i (4- or 8-fold reduction in the MIC). The in vitro efficacy $\left(k_{2} / K_{\mathrm{i}}\right)$ of the latter compounds was in the 1,600 to $3,700 \mathrm{M}^{-1} \mathrm{~s}^{-1}$ range. These values are similar to those of DBOs $\mathbf{8 g}, \mathbf{8 h}$, and $\mathbf{8 i}\left(3,100\right.$ to $3,700 \mathrm{M}^{-1} \mathrm{~s}^{-1}$ range) that afforded a 512-fold reduction in the MICs of cefamandole. The difference between the antibacterial activity of the two series of compounds ( $7 \mathbf{g}-7 \mathbf{i}$ versus $\mathbf{8 g - 8 i )}$ may therefore result from a poor penetration of the Boc-containing compounds though the outer membrane of the tested strain. To further investigate the impact of the 
functionalization of the triazole ring, we synthesized regioisomers $10 \mathbf{a}$ and $\mathbf{1 0 b}$ containing unsubstituted triazoles. The inactivation efficacy of these compounds $\left(k_{2} / K_{\mathrm{i}}\right.$ of 2,600 and 1,200 $\mathrm{M}^{-1} \mathrm{~s}^{-1}$, respectively) was similar to that of compounds containing a substituted triazole ring (up to $\left.4,700 \mathrm{M}^{-1} \mathrm{~s}^{-1}\right)$, but $c a$. 19- and 9-fold lower than that of avibactam $\left(88,000 \mathrm{M}^{-1} \mathrm{~s}^{-1}\right)$ and relebactam $\left(43,000 \mathrm{M}^{-1} \mathrm{~s}^{-1}\right)$. These results indicate that the triazole linkage is disfavored in comparison to the carboxamide of avibactam or to the amide of relebactam. None of the tested side chains fully compensated this effect in vitro. Of note, inhibition of TEM-1 by avibactam and 10b was reversible with similar off-rate constants (Supplementary Figure S1).

Efficacy of carbapenemase inhibition by DBOs. KPC-2 was fully inhibited by the two reference DBOs, avibactam and relebactam, affording a 4,096-fold reduction in the MIC of aztreonam used as the reporter drug for this $\beta$-lactamase (Table 3). Clavulanate was inactive as expected. ${ }^{35}$ Among the DBOs synthesized in this study, $\mathbf{7 a}, \mathbf{7 f}, \mathbf{8 g}$, and $\mathbf{8 h}$ were the most active in vivo, affording a 64-fold reduction in the MIC of aztreonam. However, the MIC of aztreonam in the presence of these inhibitors ( $\mathrm{MIC}=32 \mu \mathrm{g} / \mathrm{ml}$ ) was much higher than that obtained with avibactam and relebactam $(\mathrm{MIC}=0.5 \mu \mathrm{g} / \mathrm{ml})$ indicating that $\mathrm{KPC}-2$ retained substantial hydrolytic activity when the inhibitors were added to the culture medium. The difference in the MICs conveyed by $\mathbf{7 a}, \mathbf{7 f}, \mathbf{8 g}$, and $\mathbf{8 h}$ in comparison to avibactam and relebactam correlated with a $>20$-fold lower inhibition efficacy in vitro $\left(k_{2} / K_{\mathrm{i}}\right.$ in the 120 to $550 \mathrm{M}^{-1} \mathrm{~s}^{-1}$ range for $7 \mathbf{a}$, 7f, $8 \mathrm{~g}$, and $\mathbf{8 h}$ versus 26,000 and $10,000 \mathrm{M}^{-1} \mathrm{~s}^{-1}$ for avibactam and relebactam, respectively). Comparisons of the data obtained with DBOs containing unsubstituted triazole rings (10a and $\mathbf{1 0 b} ; k_{2} / K_{\mathrm{i}}$ of 350 and $280 \mathrm{M}^{-1} \mathrm{~s}^{-1}$, respectively) indicate that the side chain of three DBOs, $7 \mathbf{a}$, $\mathbf{7 b}$, and $7 \mathbf{i}$ had a favorable impact on the inactivation efficacy $\left(k_{2} / K_{\mathrm{i}}\right.$ of 550,930 , and $1,100 \mathrm{M}^{-}$ ${ }^{1} \mathrm{~s}^{-1}$, respectively). Several side chains were poorly tolerated by KPC-2, including a trimethylsilyl in $7 \mathbf{c}\left(k_{2} / K_{\mathrm{i}}=97 \mathrm{M}^{-1} \mathrm{~s}^{-1}\right)$, a methoxy in $7 \mathbf{d}\left(18 \mathrm{M}^{-1} \mathrm{~s}^{-1}\right)$, and a carboxylate in $7 \mathbf{j}$ $\left(70 \mathrm{M}^{-1} \mathrm{~s}^{-1}\right)$ 
Table 3. Inhibition of class A $\beta$-lactamases by DBOs and clavulanate

\begin{tabular}{|c|c|c|c|c|c|c|c|}
\hline \multirow{3}{*}{$\mathrm{R=}$} & & \multicolumn{3}{|c|}{ Inhibition of KPC-2 } & \multicolumn{3}{|c|}{ Inhibition of CTX-M-15 } \\
\hline & & \multirow[b]{2}{*}{$\begin{array}{c}\text { Carbamoylation } \\
\text { efficacy } \\
\left(\mathrm{M}^{-1} \mathrm{~s}^{-1}\right)\end{array}$} & \multicolumn{2}{|c|}{$\begin{array}{c}\text { MIC of aztreonam } \\
(\mu \mathrm{g} / \mathrm{ml})\end{array}$} & \multirow[b]{2}{*}{$\begin{array}{c}\text { Carbamoylation } \\
\text { efficacy } \\
\left(\mathrm{M}^{-1} \mathrm{~s}^{-1}\right)\end{array}$} & \multicolumn{2}{|c|}{$\begin{array}{c}\text { MIC of amoxicillin } \\
(\mu \mathrm{g} / \mathrm{ml})\end{array}$} \\
\hline & & & $\begin{array}{l}\text { Without } \\
\text { KPC-2 }\end{array}$ & $\begin{array}{l}\text { With } \\
\text { KPC-2 }\end{array}$ & & $\begin{array}{c}\text { Without } \\
\text { CTX-M-15 }\end{array}$ & $\begin{array}{c}\text { With } \\
\text { CTX-M- } \\
15\end{array}$ \\
\hline no inhibitor & & NA & 0.5 & 2,048 & NA & 8 & 2,048 \\
\hline & Avibactam & $\begin{array}{c}26,000 \pm \\
1,000\end{array}$ & 0.25 & 0.5 & $\begin{array}{c}130,000 \pm \\
10,000\end{array}$ & 2 & 2 \\
\hline & $\begin{array}{l}\text { Relebacta } \\
\mathrm{m}\end{array}$ & $\begin{array}{c}10,000 \pm \\
1,000\end{array}$ & 0.25 & 0.5 & $\begin{array}{c}960 \pm \\
80\end{array}$ & 2 & 16 \\
\hline & $7 \mathrm{a}$ & $\begin{array}{c}550 \pm \\
10\end{array}$ & 0.25 & 32 & $\begin{array}{c}1,700 \pm \\
400\end{array}$ & 2 & 32 \\
\hline & $7 b$ & $\begin{array}{c}930 \pm \\
40\end{array}$ & 0.25 & 64 & $\begin{array}{c}6,900 \pm \\
2,000\end{array}$ & 8 & 64 \\
\hline & $7 \mathrm{c}$ & $\begin{array}{c}97 \pm \\
8\end{array}$ & 0.5 & 512 & $\begin{array}{c}400 \pm \\
10\end{array}$ & 8 & 1,024 \\
\hline & $7 \mathrm{~d}$ & $\begin{array}{c}18 \pm \\
2\end{array}$ & 0.5 & 512 & $\begin{array}{c}120 \pm \\
40\end{array}$ & 8 & 256 \\
\hline & $7 \mathrm{e}$ & $\begin{array}{c}120 \pm \\
50\end{array}$ & 0.5 & 64 & $\begin{array}{c}29 \pm \\
5\end{array}$ & 4 & 256 \\
\hline & $7 f$ & $\begin{array}{c}190 \pm \\
20\end{array}$ & 0.25 & 32 & $\begin{array}{c}100 \pm \\
10\end{array}$ & 8 & 64 \\
\hline & $7 \mathrm{~g}$ & $\begin{array}{c}540 \pm \\
60\end{array}$ & 0.25 & 512 & $\begin{array}{c}130 \pm \\
10\end{array}$ & 8 & 1,024 \\
\hline & $7 \mathrm{~h}$ & $\begin{array}{c}830 \pm \\
90\end{array}$ & 0.25 & 2,048 & $\begin{array}{c}230 \pm \\
30\end{array}$ & 8 & 4,096 \\
\hline & $7 \mathrm{i}$ & $\begin{array}{c}1,100 \pm \\
200\end{array}$ & 0.5 & 512 & $\begin{array}{c}2,400 \pm \\
200\end{array}$ & 8 & 768 \\
\hline & $8 \mathrm{~g}$ & $\begin{array}{c}120 \pm \\
10\end{array}$ & 0.25 & 32 & $\begin{array}{c}88 \pm \\
13\end{array}$ & 4 & 128 \\
\hline & $8 \mathrm{~h}$ & $\begin{array}{c}340 \pm \\
30\end{array}$ & 0.25 & 32 & $\begin{array}{c}350 \pm \\
60\end{array}$ & 4 & 64 \\
\hline & $8 \mathrm{i}$ & $\begin{array}{c}180 \pm \\
33\end{array}$ & 0.25 & 64 & $\begin{array}{c}150 \pm \\
10\end{array}$ & 4 & 128 \\
\hline & $7 \mathrm{j}$ & $\begin{array}{r}70 \\
\pm 8\end{array}$ & 0.25 & 256 & $\begin{array}{c}110 \pm \\
10\end{array}$ & 2 & 96 \\
\hline & $10 \mathrm{a}$ & $\begin{array}{r}350 \\
\pm 40 \\
\end{array}$ & 0.5 & 512 & $\begin{array}{c}120 \pm \\
10\end{array}$ & 4 & 512 \\
\hline & $10 \mathrm{~b}$ & $\begin{array}{r}280 \\
\pm 30 \\
\end{array}$ & 0.25 & 512 & $\begin{array}{c}280 \pm \\
10\end{array}$ & 8 & 64 \\
\hline $\mathrm{CO}_{2} \mathrm{H}$ & $\begin{array}{c}\text { Clavulanat } \\
\mathrm{e}\end{array}$ & NA & 0.5 & 512 & NA & 8 & 2 \\
\hline
\end{tabular}

NA, not applicable as clavulanate and DBOs have different modes of action. Kinetics constants

were deduced from a minimum of six progress curves obtained in a minimum of two independent experiments. Reported MICs are the medians from five biological repeats obtained in two independent experiments. ${ }^{[a]}$ Zwitterionic species have been tested. 
Efficacy of extended-spectrum $\beta$-lactamase inhibition by DBOs. Inhibition of CTX-M-15 was tested with amoxicillin as the reporter drug (Table 3). Avibactam fully inhibited CTX-M15 in vivo ( $\mathrm{MIC}=2 \mu \mathrm{g} / \mathrm{ml}$ ) but $\mathrm{CTX}-\mathrm{M}-15$ retained partial activity in bacteria exposed to relebactam $(\mathrm{MIC}=16 \mu \mathrm{g} / \mathrm{ml})$. In comparison with unsubstituted DBOs 10a and $10 \mathbf{b}\left(k_{2} / K_{\mathrm{i}}\right.$ of 120 and $280 \mathrm{M}^{-1} \mathrm{~s}^{-1}$, respectively), the pyridine and phenyl groups present in $7 \mathbf{a}, 7 \mathbf{b}$, and $7 \mathbf{i}$ enhanced CTX-M-15 inactivation $\left(k_{2} / K_{\mathrm{i}}\right.$ of $1,700,6,900$, and $2,400 \mathrm{M}^{-1} \mathrm{~s}^{-1}$, respectively). However, these compounds displayed $>18$-fold lower in vitro efficacies in comparison to avibactam and, accordingly, $\mathbf{7 a}$ and $\mathbf{7 b}$ did not fully restore the antibacterial activity of amoxicillin (MIC of 32 and $64 \mu \mathrm{g} / \mathrm{ml}$, respectively). Relebactam was less active than $7 \mathbf{a}$ and 7b in vitro (960 versus 1,700 and $6,900 \mathrm{M}^{-1} \mathrm{~s}^{-1}$ ). Accordingly, relebactam failed to fully inhibit CTX-M-15 in vivo $(\mathrm{MIC}=16 \mu \mathrm{g} / \mathrm{ml})$. DBO $7 \mathbf{i}$ only afforded an 8-fold reduction in the MIC of amoxicillin in agreement with the proposed negative impact of the Boc group on permeability described above. Of note, four DBOs (avibactam, relebactam, 7a and 7j) slightly increased (4fold) the activity of amoxicillin against the E. coli TOP10 host, which does not produce CTXM-15. These results suggest that these DBOs may inhibit PBP targets in addition to the $\beta$ lactamase. This would imply that the DBOs and amoxicillin may inhibit the targets in a cooperative manner leading to a higher antibacterial activity in comparison to amoxicillin alone. Of note, inhibition of class B PBP2 has been documented for several DBOs. ${ }^{23,24}$

Inhibition of class C and D $\boldsymbol{\beta}$-lactamases by DBOs. Production of AmpC in the E. coli Top10 host led to a 2,048-fold increase in the MIC of cefotaxime (from 0.125 to $256 \mu \mathrm{g} / \mathrm{ml}$ ). In vivo inhibition of AmpC (class C) was partial for avibactam $(\mathrm{MIC}=1 \mu \mathrm{g} / \mathrm{ml})$ and nearly complete for relebactam $(\mathrm{MIC}=0.25 \mu \mathrm{g} / \mathrm{ml})$. The DBOs synthesized in this study achieved moderate MIC reduction and their in vitro inhibition efficacy was $c a$. 100-fold lower than that of the reference DBOs (avibactam and relebactam) (Table 4). The largest fold reductions in the MICs were obtained with 10a and 10b containing an unsubstituted triazole ring (from 256 to 32 and 
$16 \mu \mathrm{g} / \mathrm{ml}$, respectively). Accordingly, these two compounds were the most active in vitro (200 and $210 \mathrm{M}^{-1} \mathrm{~s}^{-1}$ ) indicating that none of the side chains had a positive impact on inhibition efficacy. DBOs $\mathbf{7 b}$ and $7 \mathbf{i}$ were as active in vitro as DBOs $\mathbf{1 0 a}$ and $\mathbf{1 0 b}$ containing unsubstituted triazole rings. The side chain of other compounds had a negative impact leading to 5- to 13fold lower inhibition efficacies. Avibactam was the only DBO that significantly reduced the MIC of ertapenem against $E$. coli Top10 producing class D OXA-48 although the drug retained substantial antibacterial activity ( $\mathrm{MIC}=0.5 \mu \mathrm{g} / \mathrm{ml}$ versus $<0.03 \mu \mathrm{g} / \mathrm{ml}$ in the absence of OXA48 production). In vitro evaluation indicated that four DBOs $(\mathbf{7 b}, \mathbf{7 g}, \mathbf{7 h}$, and $\mathbf{7 i})$ inhibited OXA48 with efficacies similar to those of compounds $\mathbf{1 0 a}$ and $\mathbf{1 0 b}$, which contained unsubstituted triazole rings $\left(k_{2} / K_{\mathrm{i}}\right.$ ranges of 110 to 210 versus 140 to $150 \mathrm{M}^{-1} \mathrm{~s}^{-1}$, respectively). The side chains of other DBOs, including that of relebactam, were detrimental since no inhibition was detected at the highest concentration that was tested $(100 \mu \mathrm{M})$.

Table 4. Inhibition of class C (AmpC) and class D (OXA-48) $\beta$-lactamases by DBOs and clavulanate

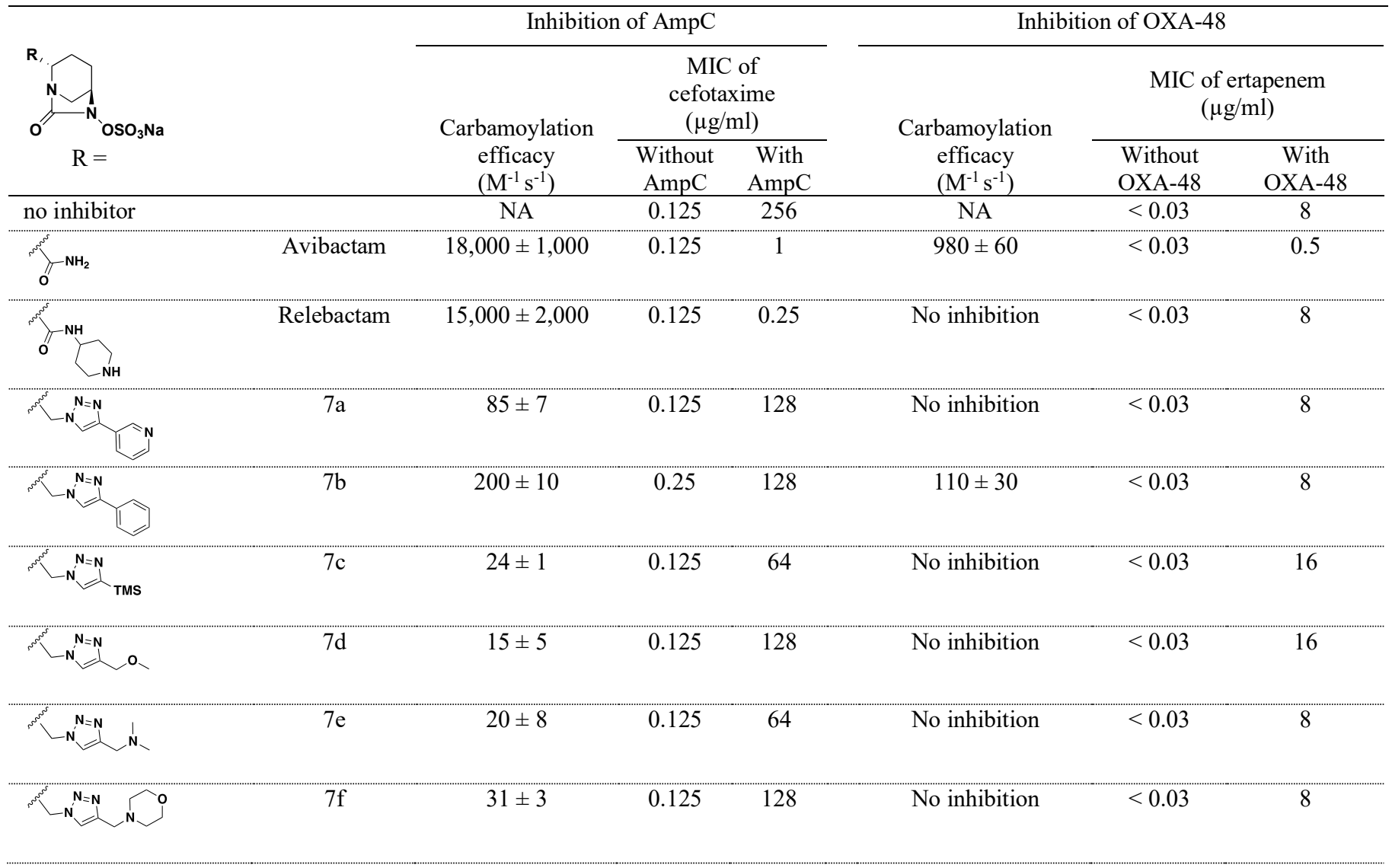




1

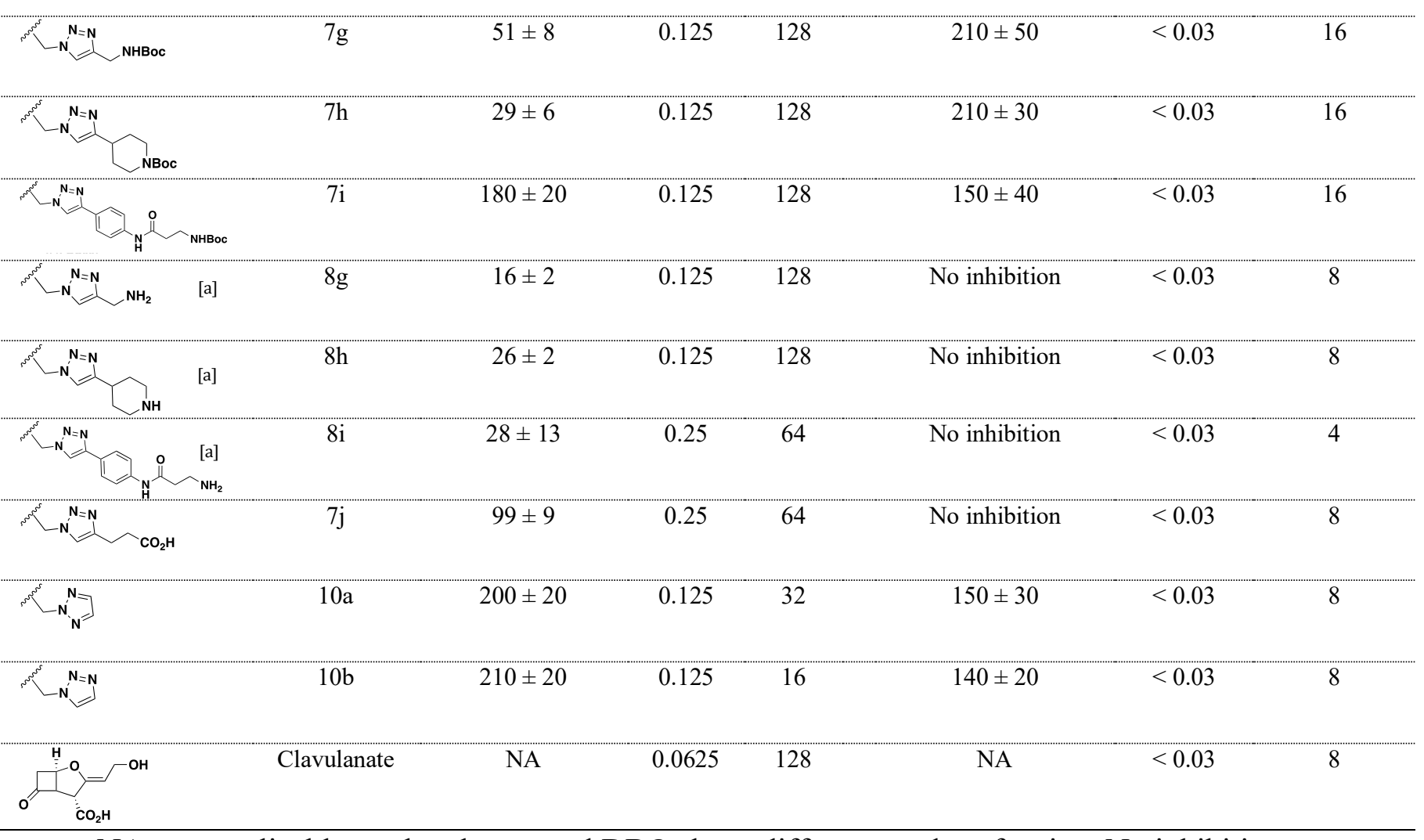

NA, not applicable as clavulanate and DBOs have different modes of action. No inhibition, no inhibition at the highest inhibitor concentration that was tested $(100 \mu \mathrm{M})$. Kinetics constants were deduced from a minimum of six progress curves obtained in a minimum of two independent experiments. Reported MICs are the medians from five biological repeats obtained in two independent experiments. ${ }^{[a]}$ Zwitterionic species have been tested.

Evaluation of antibacterial activity against clinical isolates. The capacity of DBOs to restore the activity of $\beta$-lactams against $\beta$-lactam-producing clinical isolates of enterobacteria was tested for a subset of the compounds synthesized in this study (Supplementary Table S2 and S3). The data obtained with clinical isolates were in agreement with the inhibition profiles determined by in vitro inhibition of $\beta$-lactamases and antibacterial evaluation in isogenic strains of $E$. coli (Tables 2, 3 , and 4). In particular, the most active compounds, such as $7 \mathbf{a}$, restored the activity of $\beta$-lactams against clinical isolates producing TEM-1, KPC-2, and CTX-M-15, alone or in combination. 


\section{Role of asparagine 132 in the carbamoylation efficacy of KPC-2 and CTX-M-15 by DBOs.}

The crystal structure of KPC-2 and CTX-M-15 acylated by avibactam revealed hydrogen interaction between the oxygen of the avibactam carboxamide group and the amine in the carboxamide group of Asn at position 132 of the $\beta$-lactamases (Ambler numbering) (Figure 4). ${ }^{10,36,37}$ To assess the role of this interaction, we further characterized derivatives of KPC-2 and CTX-M-15 harboring an $\mathrm{N}^{132} \mathrm{G}$ substitution in the conserved SDN motif. This substitution was previously shown to impair (>1,000-fold) the efficacy of carbamoylation of KPC-2 and CTX-M-15 by avibactam whereas hydrolysis of nitrocefin was moderately ( $\leq 3$ fold) affected. ${ }^{38}$ In this study, we compared the impact of the $\mathrm{N}^{132} \mathrm{G}$ substitution on the carbamoylation efficacy of the $\beta$-lactamases by avibactam, 10b (unsubstituted triazole), and $\mathbf{7 b}$ (phenyl-substituted triazole) (Table 5).

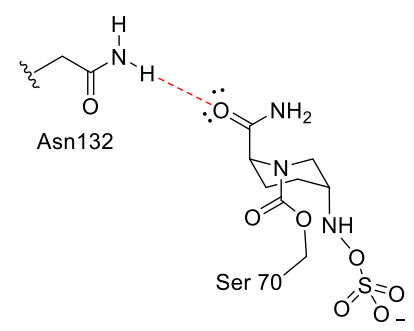

Figure 4. Hydrogen interaction between the carboxamides of avibactam and Asn at position 132 of $\beta$-lactamases (Ambler numbering).

Table 5. Impact of the $\mathrm{N}^{132} \mathrm{G}$ substitution on the cabamoylation efficacy $\left(k_{2} / K_{\mathrm{i}}\right)$ of KPC-2 and CTX-M-15 by DBOs

\begin{tabular}{lccc}
\hline & \multicolumn{3}{c}{$\boldsymbol{k}_{\mathbf{2}} / \boldsymbol{K}_{\mathbf{i}}\left(\mathbf{M}^{-\mathbf{1}} \mathbf{s}^{-\mathbf{1}}\right)$ for indicated DBO } \\
\cline { 2 - 4 } $\boldsymbol{\beta}$-lactamase & Avibactam & $\mathbf{1 0 b}$ & $\mathbf{7 b}$ \\
\hline $\mathrm{KPC}-2$ & $26,000 \pm 1,000$ & $280 \pm 30$ & $930 \pm 40$ \\
$\mathrm{KPC}-2 \mathrm{~N}^{132} \mathrm{G}$ & $53 \pm 3$ & $31 \pm 6$ & $21 \pm 3$ \\
$\mathrm{CTX}-\mathrm{M}-15$ & $130,000 \pm 10,000$ & $280 \pm 10$ & $6,900 \pm 200$ \\
$\mathrm{CTX}-\mathrm{M}-15 \mathrm{~N}^{132} \mathrm{G}$ & $70 \pm 6$ & $6.6 \pm 2.0$ & $140 \pm 10$ \\
\hline
\end{tabular}


In comparison to avibactam, the substitution had a lower impact on the efficacy of carbamoylation of KPC-2 and CTX-M-15 by $\mathbf{1 0 b}$ and $\mathbf{7 b}$. The latter compounds were much less active than avibactam against the wild-type enzymes but as active as avibactam against KPC-2 and CTX-M-15 harboring $\mathrm{N}^{132} \mathrm{G}$. These observations suggest that the hydrogen interaction between avibactam and $\mathrm{N}^{132}$ is critical for efficacious carbamoylation of KPC-2 and CTX-M-15 by avibactam and that the absence of this interaction in the case of triazolecontaining DBOs could be largely responsible for their lower efficacy in comparison to avibactam. The modest $k_{2} / K_{\mathrm{i}}$ reductions observed for $\mathbf{1 0 b}$ and $\mathbf{7 b}$ following introduction of $\mathrm{N}^{132} \mathrm{G}$ could be accounted for by additional roles of $\mathrm{N}^{132}$ or a weak interaction of the latter residue with the triazole ring. The role of the hydrogen interaction involving $\mathrm{N}^{132}$ is also highlighted by comparison of relebactam and compound $\mathbf{8 h}$ that contain the same side chain connected to the DBO scaffold by an amide or triazole, respectively.

\section{CONCLUSIONS}

Efficacies of the 17 DBOs for inhibition of TEM-1, KPC-2, CTX-M-15, AmpC, and OXA-48 were recapitulated in a heat map (Figure 5A) to highlight key differences. Compounds 10a and 10b, containing unsubstituted triazole rings, were less active than the reference DBOs (avibactam and relebactam) against TEM-1, KPC-2, CTX-M-15, and AmpC. Loss of the hydrogen interaction between the carboxamide of avibactam and conserved residue $\mathrm{N}^{132}$ is likely to be responsible for reduced activity that could not be fully compensated by any of the substituents introduced in the triazole ring. In comparison to $\mathbf{1 0 a}$ and $\mathbf{1 0 b}$, two DBOs, $\mathbf{7 a}$ and 7b, displayed improved inhibition efficacies, in particular against the KPC-2 carbapenemase and the CTX-M-15 extended-spectrum $\beta$-lactamase, indicating that the pyridine and phenylgroups present in $\mathbf{7 a}$ and $\mathbf{7 b}$ had a positive impact on the inhibition of these class A $\beta$ lactamases. Several side chains had a deleterious effect, in particular the methoxy and carboxyl groups present in $\mathbf{7 d}$ and $\mathbf{7 j}$. In vivo antibacterial susceptibility data were recapitulated in a heat 
map presented in Figure 5B. The most active DBOs in vitro (7a and $7 \mathbf{b})$ were also among the most active compounds for restoring the activity of $\beta$-lactams against KPC-2- or CTX-M-15producing E. coli strains.
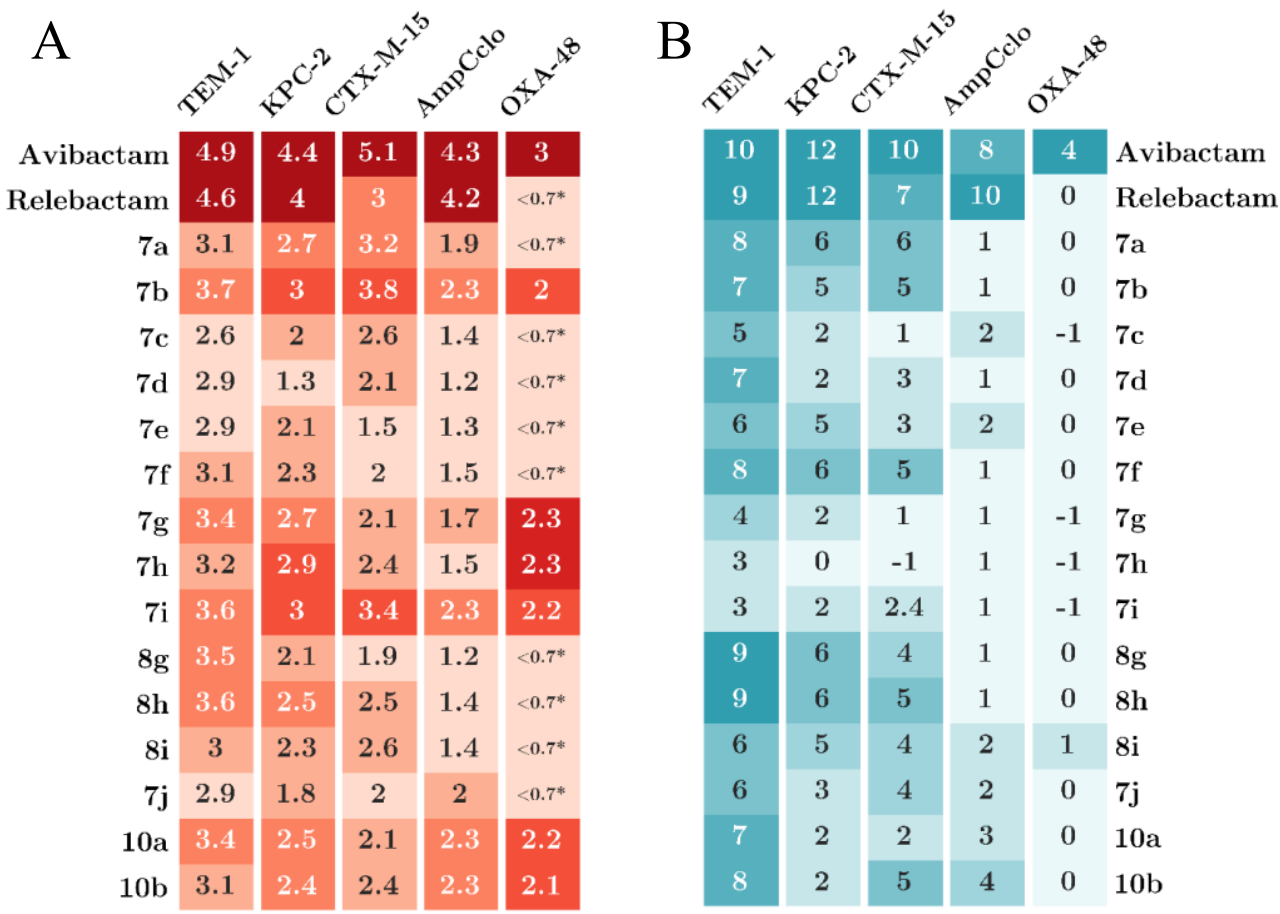

Figure 5. Heat maps highlighting differences in (A) the efficacy of in vitro inhibition of $\beta$ lactamases $\left(\log _{10}\right.$ of $\left.k_{2} / K_{\mathrm{i}}\right)$ and $(\mathrm{B})$ the antibacterial activity $\left(\log _{2}\right.$ of the fold reduction in the MICs). *: No inhibition at the highest inhibitor concentration that was tested (100 $\mu \mathrm{M})$. The color code shows the activities relative to the most active compound for each $\beta$-lactamase. Darker color indicates higher activity.

The correlation between antibacterial activity and in vitro inhibition efficacies did not appear to apply to all DBOs, in particular for DBOs containing protected amines, which appeared to be less active in vivo than expected from their in vitro activity. This was explored by plotting the in vitro efficacy of the DBOs against the fold reduction of the MICs they afforded (Figure 6A). Plotting the complete set of data, i.e. the inhibition of five $\beta$-lactamases by 17 DBOs, revealed a positive correlation between the $\log _{10}$ of the inhibition efficacy $\left(\log _{10}\right.$ of $\left.k_{2} / K_{\mathrm{i}}\right)$ and 
the $\log _{2}$ of the fold reduction in the MIC of the reporter drugs (Spearman correlation coefficient of $0.72 ; p=5.310^{-14}$ ). DBOs harboring a Boc group in their side chain clustered below the regression line indicating that their in vitro efficacy was not translated into antibacterial activity due to impaired penetration through the outer membrane (Figure 6B). The Spearman correlation coefficient calculated without Boc-containing compounds was higher than that calculated with the entire set of data $\left(0.87 ; p=4.710^{-21}\right)$. In contrast, amine-containing compounds clustered above the regression line indicating a facilitated access to the periplasm (Figure 6C).
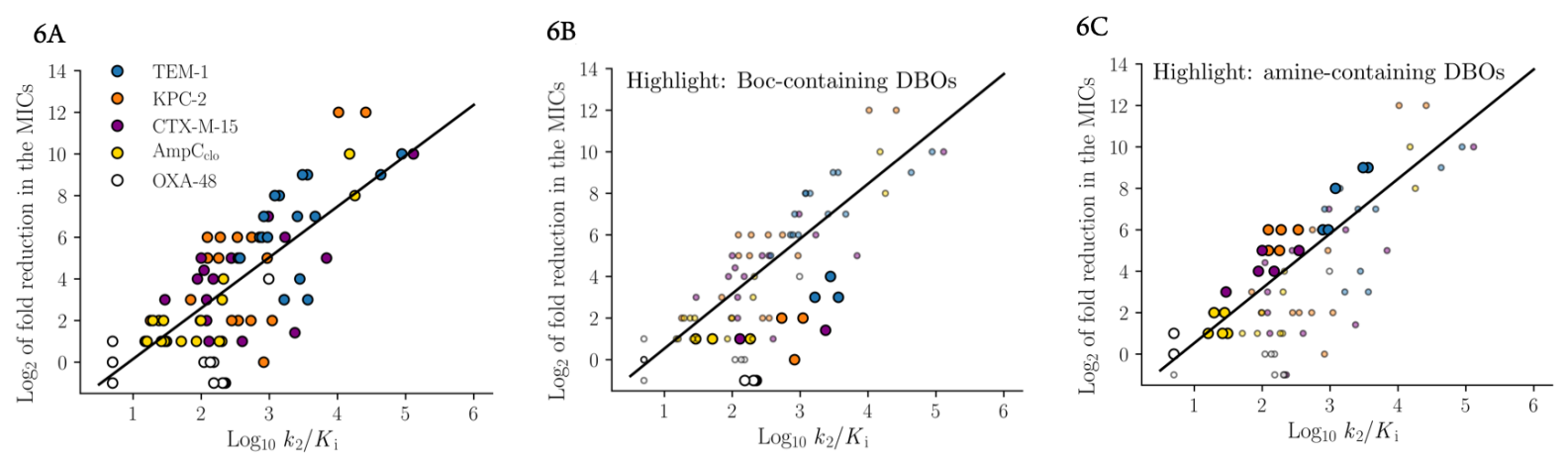

Figure 6. Correlation between the efficacy of DBOs in reducing MICs and in inhibiting $\beta$ lactamases. The trend line was obtained by linear regression. (A) Complete set of data. (B) The regression line was calculated by omitting Boc-containing DBOs (highlighted with large circles). (C) Clustering of amine-containing DBOs above the regression line (highlighted with large circles).

To summarize, we have developed an efficient strategy based on copper(I)-catalyzed HuisgenSharpless cycloaddition reaction for the synthesis of new DBOs. To achieve this goal, a modification of the original synthesis of azido derivative $\mathbf{4}$ has been realized. Our methodology is compatible with a wide range of functional groups for the modification of the $\mathrm{C} 2$ position of the DBO scaffold. The synthetic route provides a versatile approach to explore the chemical space for novel interactions with the catalytic cavity of potential targets. ${ }^{3,23,24,32}$ Although the first series of triazole-containing compounds reported in this study did not lead to inhibitors 
with improved characteristics for inhibition of $\beta$-lactamases of Gram-negative bacteria. The reduced efficacy could be due to the absence of hydrogen bonding with a conserved asparagine residue at position 132 . This could only be partially compensated by additional interactions involving the triazole substituents.

\section{EXPERIMENTAL SECTION}

General procedures. Reactions were carried out under argon atmosphere and solvents were dried using standard methods and distilled before use. Unless otherwise specified, materials were purchased from commercial suppliers and used without further purification. TLC was performed using Merck commercial aluminum sheets coated with silica gel $60 \mathrm{~F}_{254}$. Compounds were detected by charring with phosphomolibdic acid in ethanol followed by heating. Purification was performed by flash chromatography on silica gel (60 A, 180-240 mesh; Merck) or by preparative high-performance liquid chromatography (HPLC) using Shimadzu Prominence system with a Zorbax Extend-C18 prepHT column $(150$ x $21.2 \mathrm{~mm}, 5 \mu \mathrm{m}$; Agilent). Compounds were eluted with a linear gradient (from $100 \%$ of $\mathrm{H}_{2} \mathrm{O}$ to $100 \%$ of $\mathrm{CH}_{3} \mathrm{CN}$ ) that was applied between 5 and $30 \mathrm{~min}$ at a flow rate of $15 \mathrm{ml} / \mathrm{min}$. Products were detected by UV absorption at $214 \mathrm{~nm}$. NMR spectra were recorded on Bruker spectrometers (AM250, Avance II 500 and Avance III HD 4000). Chemical shifts ( $\delta$ ) are reported in ppm and referenced to the residual proton or carbon resonance of the solvents: $\mathrm{CDCl}_{3}(\delta 7.26), \mathrm{D}_{2} \mathrm{O}(\delta$ 4.79) or $\left(\mathrm{CD}_{3}\right)_{2} \mathrm{SO}(\delta 2.50)$ for ${ }^{1} \mathrm{H}$ and $\mathrm{CDCl}_{3}(\delta 77.16)$ or $\left(\mathrm{CD}_{3}\right)_{2} \mathrm{SO}(\delta 39.52)$ for ${ }^{13} \mathrm{C}$. Signals were assigned using $1 \mathrm{D}\left({ }^{1} \mathrm{H}\right.$ and $\left.{ }^{13} \mathrm{C}\right)$ and 2D (HSQC, COSY, and HMBC) spectra. NMR coupling constants $(\mathrm{J})$ are reported in hertz $(\mathrm{Hz})$. High-resolution mass spectroscopy (HRMS) was recorded with an ion trap mass analyzer under electrospray ionization (ESI) in the negative or positive ionization detection mode. HRMS was performed using Thermo Scientific LTQ Orbitrap XL and Bruker MaXis II ETD spectrometers. The purity of final compounds ( $\geq 95 \%)$ was etablished by analytical HPLC, which was performed on a Shimadzu Prominence system 
with a Hypersil® BDS C18 column $(150 \times 4.6 \mathrm{~mm}, 5 \mu \mathrm{m})$ or an Agilent Zorbax Extend C18 column $(250 \times 4.6 \mathrm{~mm}, 5 \mu \mathrm{m})$ with UV detection at 214 and $220 \mathrm{~nm}$. Optical rotations were measured with a sodium lamp $(589 \mathrm{~nm})$ at $20^{\circ} \mathrm{C}$ on a Perkin Elmer polarimeter.

Compound (4). Isobutyl chloroformate $(6.26 \mathrm{ml}, 47.1 \mathrm{mmol})$ was added dropwise at $0^{\circ} \mathrm{C}$ to a solution of (2S,5R)-6-(benzyloxy)-7-oxo-1,6-diazabicyclo[3.2.1]octane-2-carboxylic acid 2 $(6.5 \mathrm{~g}, 23.5 \mathrm{mmol})$ and triethylamine $(3.64 \mathrm{ml}, 25.9 \mathrm{mmol})$ in THF $(75 \mathrm{ml})$. The solution was stirred at $0^{\circ} \mathrm{C}$ for $2 \mathrm{~h}$ and $\mathrm{NaBH}_{4}(2.72 \mathrm{~g}, 70.6 \mathrm{mmol})$ was gradually added. The reaction mixture was stirred for 3 additional hours at $0^{\circ} \mathrm{C}$. Water $(110 \mathrm{ml})$ and ethyl acetate $(110 \mathrm{ml})$ were slowly added and the heterogeneous mixture was stirred for $30 \mathrm{~min}$ at room temperature. The organic layer was washed with brine, dried over $\mathrm{MgSO}_{4}$, and concentrated under reduced pressure to afford (2S,5R)-6-(benzyloxy)-2-(hydroxymethyl)-1,6-diazabicyclo[3.2.1] octan-7-one 3, which was used in the next step without further purification. Triethylamine $(9.94 \mathrm{ml}, 70.6 \mathrm{mmol})$, DMAP (4.36 g, $35.3 \mathrm{mmol})$ and Mesyl Chloride $(2.76 \mathrm{ml}, 35.3 \mathrm{mmol})$ were added at $0^{\circ} \mathrm{C}$ to a solution of crude product $(23.5 \mathrm{mmol})$ in $\mathrm{DCM}(71 \mathrm{ml})$. The reaction mixture was stirred at $0^{\circ} \mathrm{C}$ for $2 \mathrm{~h}$. DCM was then added and the organic layer was washed with brine, dried over $\mathrm{MgSO}_{4}$, and concentrated under vacuum to afford ((2S,5R)-6-(benzyloxy)-7-oxo-1,6diazabicyclo[3.2.1]octan-2-yl)methyl methanesulfonate, which was used in the next step without further purification. Sodium azide $(7.69 \mathrm{~g}, 117 \mathrm{mmol})$ was added to a solution of ((2S,5R)-6-(benzyloxy)-7-oxo-1,6-diazabicyclo[3.2.1]octan-2-yl)methyl methanesulfonate (23.5 mmol) in DMF $(95 \mathrm{ml})$. The solution was stirred at $90^{\circ} \mathrm{C}$ for $20 \mathrm{~h}$. After being cooled to room temperature, ethyl acetate was added and the organic layer was washed with brine, dried over $\mathrm{MgSO}_{4}$, and concentrated under reduce pressure. Purification by flash chromatography using cyclohexane/ethyl acetate (7/3) as the eluent gave compound 4 as a white solid $(2.4 \mathrm{~g}$, $35 \%$ over 3 steps). ${ }^{1} \mathrm{H}$ NMR (500 MHz, $\left.\mathrm{CDCl}_{3}\right) \delta 7.43-7.33\left(\mathrm{~m}, 5 \mathrm{H}, \mathrm{H}_{10,11,12}\right), 5.04(\mathrm{~d}, J=11.5$ $\left.\mathrm{Hz}, 1 \mathrm{H}, \mathrm{H}_{8}\right), 4.89$ (d, $\left.J=11.5 \mathrm{~Hz}, 1 \mathrm{H}, \mathrm{H}_{8}\right), 3.61-3.56\left(\mathrm{~m}, 1 \mathrm{H}, \mathrm{H}_{1}\right), 3.53(\mathrm{dd}, J=12.5,7.4 \mathrm{~Hz}$, 
$\left.1 \mathrm{H}, \mathrm{H}_{7}\right), 3.35-3.32\left(\mathrm{~m}, 2 \mathrm{H}, \mathrm{H}_{4}, 7\right), 2.97\left(\mathrm{~s}, 2 \mathrm{H}, \mathrm{H}_{5}\right), 2.06-2.02\left(\mathrm{~m}, 1 \mathrm{H}, \mathrm{H}_{3}\right), 2.01-1.95(\mathrm{~m}, 1 \mathrm{H}$, $\left.\mathrm{H}_{2}\right), 1.63-1.55\left(\mathrm{~m}, 1 \mathrm{H}, \mathrm{H}_{3}\right), 1.54-1.49\left(\mathrm{~m}, 1 \mathrm{H}, \mathrm{H}_{2}\right) .{ }^{13} \mathrm{C} \mathrm{NMR}\left(125 \mathrm{MHz}, \mathrm{CDCl}_{3}\right) \delta 169.7\left(\mathrm{C}_{6}\right)$, $136.0\left(\mathrm{C}_{9}\right), 129.3\left(2 \mathrm{C}, \mathrm{C}_{10}\right), 128.8\left(\mathrm{C}_{12}\right), 128.6\left(2 \mathrm{C}, \mathrm{C}_{11}\right), 78.3\left(\mathrm{C}_{8}\right), 58.6\left(\mathrm{C}_{4}\right), 56.6\left(\mathrm{C}_{1}\right), 53.3$ $\left(\mathrm{C}_{7}\right), 44.1\left(\mathrm{C}_{5}\right), 20.5\left(\mathrm{C}_{2}\right), 20.0\left(\mathrm{C}_{3}\right)$. HRMS calculated for $\mathrm{C}_{14} \mathrm{H}_{18} \mathrm{~N}_{5} \mathrm{O}_{2}[\mathrm{M}+\mathrm{H}]^{+}:$288.14605; found 288.14523. $[\alpha]_{\mathrm{D}}:-53.2^{\circ}(7.8 \mathrm{mg} / \mathrm{ml}, \mathrm{MeOH})$.

General procedure for Copper(I)-catalyzed azide-alkyne cycloaddition reaction. To a solution of azido 4 in THF, were successively added alkyne 5 ( 2 eq), sodium ascorbate $(0.6$ eq, in water) and $\mathrm{CuSO}_{4}(0.3 \mathrm{eq}$, in water). The heterogeneous mixture was stirred overnight at room temperature. Ethyl acetate was added and the organic layer was washed with brine, dried over $\mathrm{MgSO}_{4}$, and concentrated under reduced pressure. The crude product was purified by flash chromatography to afford product 6.

General procedure for introduction of sodium sulphite. 10 wt. \% Pd/C (1 eq) was added to a solution of 6 in $\mathrm{MeOH}$ and the reaction mixture was stirred under $\mathrm{H}_{2}$ for $48 \mathrm{~h}$ at room temperature. Palladium was removed by filtration through celite and the filtrate concentrated. Sulfur trioxide pyridine complex (6 eq) was added to a solution of deprotected compound in pyridine and the reaction mixture was stirred for $2 \mathrm{~h}$ at room temperature. Additional $\mathrm{SO}_{3}$ pyridine complex (2 eq) was added, stirred overnight at room temperature, and pyridine was removed under reduced pressure. The crude product was solubilized in water, filtered, eluted on Dowex-Na resin with $\mathrm{H}_{2} \mathrm{O}$, and lyophilized. The residue was dissolved in EtOH, filtered, and concentrated under vacuum. HPLC purification afforded product 7.

General procedure for Boc deprotection. TFA (12 eq) was added dropwise at $0^{\circ} \mathrm{C}$ to a solution of 7 ( 1 eq) in DCM. The reaction mixture was stirred at $0^{\circ} \mathrm{C}$ for $1 \mathrm{~h}$ and concentrated under vacuum. HPLC purification afforded product $\mathbf{8}$. 
Compound (6a). Following the general procedure for CuAAC, starting from compound 4 (200 $\mathrm{mg}, 0.70 \mathrm{mmol}$ ) and 3-ethynylpyridine 5a (144 mg, $1.39 \mathrm{mmol})$, and using DCM/MeOH (96/4) as eluent for flash chromatography purification, compound $\mathbf{6 a}$ was obtained as a colorless oil (234 mg, 86\%). ${ }^{1} \mathrm{H}$ NMR (500 MHz, $\left.\mathrm{CDCl}_{3}\right) \delta 9.01$ (bs, 1H, $\left.\mathrm{H}_{14}\right), 8.57$ (bd, $J=3.8 \mathrm{~Hz}, 1 \mathrm{H}$, $\left.\mathrm{H}_{13}\right), 8.17$ (dt, $\left.J=7.9,2.0 \mathrm{~Hz}, 1 \mathrm{H}, \mathrm{H}_{11}\right), 8.05\left(\mathrm{~s}, 1 \mathrm{H}, \mathrm{H}_{8}\right), 7.42-7.33$ (m, 6H, $\mathrm{H}_{12,17,18,19)}, 5.02$ (d, $\left.J=11.5 \mathrm{~Hz}, 1 \mathrm{H}, \mathrm{H}_{15}\right), 4.88\left(\mathrm{~d}, J=11.5 \mathrm{~Hz}, 1 \mathrm{H}, \mathrm{H}_{15}\right), 4.62\left(\mathrm{dd}, J=14.3,8.3 \mathrm{~Hz}, 1 \mathrm{H}, \mathrm{H}_{7}\right)$, $4.56\left(\mathrm{dd}, J=14.3,6.5 \mathrm{~Hz}, 1 \mathrm{H}, \mathrm{H}_{7}\right), 3.92-3.87\left(\mathrm{~m}, 1 \mathrm{H}, \mathrm{H}_{1}\right), 3.38-3.36\left(\mathrm{~m}, 1 \mathrm{H}, \mathrm{H}_{4}\right), 2.99-2.92$ (m, $\left.2 \mathrm{H}, \mathrm{H}_{5}\right), 2.12-2.07\left(\mathrm{~m}, 1 \mathrm{H}, \mathrm{H}_{3}\right), 2.06-1.99\left(\mathrm{~m}, 1 \mathrm{H}, \mathrm{H}_{2}\right), 1.73-1.67\left(\mathrm{~m}, 1 \mathrm{H}, \mathrm{H}_{3}\right), 1.65-1.59$ (m, 1H, $\left.\mathrm{H}_{2}\right) .{ }^{13} \mathrm{C}$ NMR (125 MHz, $\left.\mathrm{CDCl}_{3}\right) \delta 169.4\left(\mathrm{C}_{6}\right), 149.4\left(\mathrm{C}_{13}\right), 147.3\left(\mathrm{C}_{14}\right), 145.3\left(\mathrm{C}_{9}\right)$, $135.8\left(\mathrm{C}_{16}\right), 133.2\left(\mathrm{C}_{11}\right), 129.4\left(2 \mathrm{C}, \mathrm{C}_{17}\right), 128.9\left(\mathrm{C}_{19}\right), 128.7\left(2 \mathrm{C}, \mathrm{C}_{18}\right), 126.8\left(\mathrm{C}_{10}\right), 123.9\left(\mathrm{C}_{12}\right)$, $120.5\left(\mathrm{C}_{8}\right), 78.4\left(\mathrm{C}_{15}\right), 58.4\left(\mathrm{C}_{4}\right), 56.7\left(\mathrm{C}_{1}\right), 52.1\left(\mathrm{C}_{7}\right), 43.8\left(\mathrm{C}_{5}\right), 20.5\left(\mathrm{C}_{2}\right), 19.8\left(\mathrm{C}_{3}\right)$. HRMS calculated for $\mathrm{C}_{21} \mathrm{H}_{23} \mathrm{~N}_{6} \mathrm{O}_{2}[\mathrm{M}+\mathrm{H}]^{+}$: 391.18825; found: 391.18886 . [ $\left.\alpha\right]_{\mathrm{D}}$ : $-17.9^{\circ}(8.0 \mathrm{mg} / \mathrm{ml}$, $\mathrm{MeOH})$.

Compound (6b). Following the general procedure for $\mathrm{CuAAC}$, starting from compound $\mathbf{4}$ (200 $\mathrm{mg}, 0.70 \mathrm{mmol})$ and phenylacetylene $\mathbf{5 b}(154 \mu \mathrm{l}, 1.40 \mathrm{mmol})$, and using cyclohexane/ethyl acetate (4/6) as eluent for flash chromatography purification, compound $\mathbf{6 b}$ was obtained as a colorless oil (232 mg, 85\%). ${ }^{1} \mathrm{H}$ NMR (500 MHz, $\left.\mathrm{CDCl}_{3}\right) \delta 7.97\left(\mathrm{~s}, 1 \mathrm{H}, \mathrm{H}_{8}\right), 7.83(\mathrm{~d}, J=7.2$ $\left.\mathrm{Hz}, 2 \mathrm{H}, \mathrm{H}_{11}\right), 7.43-7.32\left(\mathrm{~m}, 8 \mathrm{H}, \mathrm{H}_{12}, 13,16,17,18\right), 5.03$ (d, $\left.J=11.5 \mathrm{~Hz}, 1 \mathrm{H}, \mathrm{H}_{14}\right), 4.88(\mathrm{~d}, J=11.5$ $\left.\mathrm{Hz}, 1 \mathrm{H}, \mathrm{H}_{14}\right), 4.63-4.54\left(\mathrm{~m}, 2 \mathrm{H}, \mathrm{H}_{7}\right), 3.91-3.86\left(\mathrm{~m}, 1 \mathrm{H}, \mathrm{H}_{1}\right), 3.36-3.35\left(\mathrm{~m}, 1 \mathrm{H}, \mathrm{H}_{4}\right), 2.97-2.90$ (m, $\left.2 \mathrm{H}, \mathrm{H}_{5}\right), 2.10-2.06\left(\mathrm{~m}, 1 \mathrm{H}, \mathrm{H}_{3}\right), 2.03-1.96\left(\mathrm{~m}, 1 \mathrm{H}, \mathrm{H}_{2}\right), 1.72-1.68\left(\mathrm{~m}, 1 \mathrm{H}, \mathrm{H}_{3}\right), 1.66-1.60$ (m, 1H, $\left.\mathrm{H}_{2}\right) .{ }^{13} \mathrm{C}$ NMR $\left(125 \mathrm{MHz}, \mathrm{CDCl}_{3}\right) \delta 169.3\left(\mathrm{C}_{6}\right), 148.2\left(\mathrm{C}_{9}\right), 135.8\left(\mathrm{C}_{15}\right), 130.3\left(\mathrm{C}_{10}\right)$, $129.4\left(2 \mathrm{C}, \mathrm{C}_{16}\right), 129.0\left(2 \mathrm{C}, \mathrm{C}_{12}\right), 128.9\left(\mathrm{C}_{18}\right), 128.7\left(2 \mathrm{C}, \mathrm{C}_{17}\right), 128.5\left(\mathrm{C}_{13}\right), 126.0\left(2 \mathrm{C}, \mathrm{C}_{11}\right)$, $120.3\left(\mathrm{C}_{8}\right), 78.4\left(\mathrm{C}_{14}\right), 58.4\left(\mathrm{C}_{4}\right), 56.7\left(\mathrm{C}_{1}\right), 52.2\left(\mathrm{C}_{7}\right), 43.9\left(\mathrm{C}_{5}\right), 20.4\left(\mathrm{C}_{2}\right), 19.8\left(\mathrm{C}_{3}\right)$. HRMS

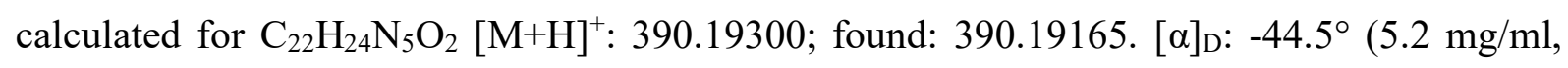
DMSO). 
Compound (6c). Following the general procedure for CuAAC, startingfrom compound 4 (200 $\mathrm{mg}, \quad 0.70 \mathrm{mmol})$ and ethynyltrimethylsilane $\mathbf{5 c}(388 \mu 1,2.80 \mathrm{mmol})$, and using cyclohexane/ethyl acetate (3/7) as eluent for flash chromatography purification, compound $\mathbf{6 c}$ was obtained as a colorless oil (82 mg, 30\%). ${ }^{1} \mathrm{H}$ NMR $\left(250 \mathrm{MHz}, \mathrm{CDCl}_{3}\right) \delta 7.64\left(\mathrm{~s}, 1 \mathrm{H}, \mathrm{H}_{8}\right)$, 7.42-7.32 (m, 5H, H $\left.\mathrm{H}_{13}, 14,15\right), 5.01\left(\mathrm{~d}, J=11.5 \mathrm{~Hz}, 1 \mathrm{H}, \mathrm{H}_{11}\right), 4.86\left(\mathrm{~d}, J=11.5 \mathrm{~Hz}, 1 \mathrm{H}, \mathrm{H}_{11}\right), 4.55$ (d, $\left.J=7.3 \mathrm{~Hz}, 2 \mathrm{H}, \mathrm{H}_{7}\right), 3.85-3.75\left(\mathrm{~m}, 1 \mathrm{H}, \mathrm{H}_{1}\right), 3.34-3.30\left(\mathrm{~m}, 1 \mathrm{H}, \mathrm{H}_{4}\right), 2.95-2.82\left(\mathrm{~m}, 2 \mathrm{H}_{1} \mathrm{H}_{5}\right)$, 2.09-1.97 (m, 1H, $\left.\mathrm{H}_{3}\right), 1.96-1.85\left(\mathrm{~m}, 1 \mathrm{H}, \mathrm{H}_{2}\right), 1.72-1.62\left(\mathrm{~m}, 1 \mathrm{H}, \mathrm{H}_{3}\right), 1.62-1.50\left(\mathrm{~m}, 1 \mathrm{H}, \mathrm{H}_{2}\right)$, $0.30\left(\mathrm{~s}, 9 \mathrm{H}, \mathrm{H}_{10}\right) .{ }^{13} \mathrm{C}$ NMR $\left(125 \mathrm{MHz}, \mathrm{CDCl}_{3}\right) \delta 169.6\left(\mathrm{C}_{6}\right), 147.3\left(\mathrm{C}_{9}\right), 135.9\left(\mathrm{C}_{12}\right), 129.4$ (3C, $\mathrm{C}_{8}$ and $\left.\mathrm{C}_{13}\right), 128.9\left(\mathrm{C}_{15}\right), 128.7\left(2 \mathrm{C}, \mathrm{C}_{14}\right), 78.4\left(\mathrm{C}_{11}\right), 58.5\left(\mathrm{C}_{4}\right), 56.8\left(\mathrm{C}_{1}\right), 51.5\left(\mathrm{C}_{7}\right), 44.0$ $\left(\mathrm{C}_{5}\right), 20.3\left(\mathrm{C}_{2}\right), 19.9\left(\mathrm{C}_{3}\right),-1.0\left(3 \mathrm{C}, \mathrm{C}_{10}\right)$. HRMS calculated for $\mathrm{C}_{19} \mathrm{H}_{28} \mathrm{~N}_{6} \mathrm{O}_{2} \mathrm{Si}[\mathrm{M}+\mathrm{H}]^{+}$: 386.20123; found: 386.20053. [ $\alpha]_{\mathrm{D}}:-24.4^{\circ}(5.6 \mathrm{mg} / \mathrm{ml}, \mathrm{MeOH})$.

Compound $(\mathbf{6 d})$. Following the general procedure for CuAAC, starting from compound 4 (200 $\mathrm{mg}, 0.70 \mathrm{mmol})$ and methyl propargyl ether 5d (118 $\mu \mathrm{l}, 1.40 \mathrm{mmol})$, and using DCM/MeOH (96/4) as eluent for flash chromatography purification, compound 6d was obtained as a colorless oil (215 mg, 86\%). ${ }^{1} \mathrm{H}$ NMR $\left(500 \mathrm{MHz}, \mathrm{CDCl}_{3}\right) \delta 7.70\left(\mathrm{~s}, 1 \mathrm{H}, \mathrm{H}_{8}\right), 7.42-7.33(\mathrm{~m}, 5 \mathrm{H}$, $\left.\mathrm{H}_{14}, 15,16\right), 5.02\left(\mathrm{~d}, J=11.5 \mathrm{~Hz}, 1 \mathrm{H}, \mathrm{H}_{12}\right), 4.87$ (d, $\left.J=11.5 \mathrm{~Hz}, 1 \mathrm{H}, \mathrm{H}_{12}\right), 4.57$ (s, 2H, H10), 4.55$4.48\left(\mathrm{~m}, 2 \mathrm{H}, \mathrm{H}_{7}\right), 3.81\left(\mathrm{qd}, J=7.4,4.2 \mathrm{~Hz}, 1 \mathrm{H}, \mathrm{H}_{1}\right), 3.40\left(\mathrm{~s}, 3 \mathrm{H}, \mathrm{H}_{11}\right), 3.34(\mathrm{q}, J=3.0 \mathrm{~Hz}, 1 \mathrm{H}$, H4), 2.93 (bd, $\left.J=11.9 \mathrm{~Hz}, 1 \mathrm{H}, \mathrm{H}_{5}\right), 2.88$ (d, $\left.J=11.9 \mathrm{~Hz}, 1 \mathrm{H}, \mathrm{H}_{5}\right), 2.09-2.03\left(\mathrm{~m}, 1 \mathrm{H}, \mathrm{H}_{3}\right), 1.97$ $\left(\mathrm{dq}, J=15.1,7.4 \mathrm{~Hz}, 1 \mathrm{H}, \mathrm{H}_{2}\right), 1.70-1.63\left(\mathrm{~m}, 1 \mathrm{H}, \mathrm{H}_{3}\right), 1.60-1.54\left(\mathrm{~m}, 1 \mathrm{H}, \mathrm{H}_{2}\right) .{ }^{13} \mathrm{C} \mathrm{NMR}(125$ $\mathrm{MHz}, \mathrm{CDCl} 3) \delta 169.4\left(\mathrm{C}_{6}\right), 145.8\left(\mathrm{C}_{9}\right), 135.9\left(\mathrm{C}_{13}\right), 129.4\left(2 \mathrm{C}, \mathrm{C}_{14}\right), 128.9\left(\mathrm{C}_{16}\right), 128.7(2 \mathrm{C}$, $\left.\mathrm{C}_{15}\right), 123.0\left(\mathrm{C}_{8}\right), 78.4\left(\mathrm{C}_{12}\right), 66.1\left(\mathrm{C}_{10}\right), 58.5\left(\mathrm{C}_{11}\right), 58.4\left(\mathrm{C}_{4}\right), 56.7\left(\mathrm{C}_{1}\right), 52.0\left(\mathrm{C}_{7}\right), 43.9\left(\mathrm{C}_{5}\right)$, $20.4\left(\mathrm{C}_{2}\right), 19.8\left(\mathrm{C}_{3}\right)$. HRMS calculated for $\mathrm{C}_{18} \mathrm{H}_{24} \mathrm{~N}_{5} \mathrm{O}_{3}[\mathrm{M}+\mathrm{H}]^{+}$: 358.18791; found: 358.218771. $[\alpha]_{\mathrm{D}}:-27.7^{\circ}(6.6 \mathrm{mg} / \mathrm{ml}, \mathrm{MeOH})$.

Compound (6e). Following the general procedure for CuAAC, starting from compound 4 (150 $\mathrm{mg}, 0.52 \mathrm{mmol})$ and 3-dimethylamino-1-propyne 5e (112 $\mu 1,1.04 \mathrm{mmol})$, and using 
$\mathrm{DCM} / \mathrm{MeOH}(9 / 1)+1 \% \mathrm{NH}_{4} \mathrm{OH}$ as eluent for flash chromatography purification, compound 6e was obtained as a pale yellow oil (169 mg, 87\%). ${ }^{1} \mathrm{H} \mathrm{NMR}\left(500 \mathrm{MHz}, \mathrm{CDCl}_{3}\right) \delta 7.65(\mathrm{~s}, 1 \mathrm{H}$, $\left.\mathrm{H}_{8}\right), 7.38-7.28\left(\mathrm{~m}, 5 \mathrm{H}, \mathrm{H}_{14,15,16}\right), 4.97\left(\mathrm{~d}, J=11.5 \mathrm{~Hz}, 1 \mathrm{H}, \mathrm{H}_{12}\right), 4.83\left(\mathrm{~d}, J=11.5 \mathrm{~Hz}, 1 \mathrm{H}, \mathrm{H}_{12}\right)$, 4.54-4.44 (m, 2H, $\left.\mathrm{H}_{7}\right), 3.79-3.74\left(\mathrm{~m}, 1 \mathrm{H}, \mathrm{H}_{1}\right), 3.56\left(\mathrm{~s}, 2 \mathrm{H}, \mathrm{H}_{10}\right), 3.36-3.34\left(\mathrm{~m}, 1 \mathrm{H}, \mathrm{H}_{4}\right), 2.95-$ $2.87\left(\mathrm{~m}, 2 \mathrm{H}, \mathrm{H}_{5}\right), 2.22\left(\mathrm{~s}, 6 \mathrm{H}, \mathrm{H}_{11}\right), 2.03-1.97\left(\mathrm{~m}, 1 \mathrm{H}, \mathrm{H}_{3}\right), 1.95-1.87\left(\mathrm{~m}, 1 \mathrm{H}, \mathrm{H}_{2}\right), 1.68-1.62$ $\left(\mathrm{m}, 1 \mathrm{H}, \mathrm{H}_{3}\right), 1.55-1.49\left(\mathrm{~m}, 1 \mathrm{H}, \mathrm{H}_{2}\right) .{ }^{13} \mathrm{C} \mathrm{NMR}\left(125 \mathrm{MHz}, \mathrm{CDCl}_{3}\right) \delta 169.4\left(\mathrm{C}_{6}\right), 143.3\left(\mathrm{C}_{9}\right)$, $135.9\left(\mathrm{C}_{13}\right), 129.4\left(2 \mathrm{C}, \mathrm{C}_{14}\right), 128.9\left(\mathrm{C}_{16}\right), 128.7\left(2 \mathrm{C}, \mathrm{C}_{15}\right), 124.2\left(\mathrm{C}_{8}\right), 78.4\left(\mathrm{C}_{12}\right), 58.4\left(\mathrm{C}_{4}\right), 56.9$ $\left(\mathrm{C}_{1}\right), 53.9\left(\mathrm{C}_{10}\right), 52.0\left(\mathrm{C}_{7}\right), 44.5\left(2 \mathrm{C}, \mathrm{C}_{11}\right), 43.7\left(\mathrm{C}_{5}\right), 20.4\left(\mathrm{C}_{2}\right), 19.8\left(\mathrm{C}_{3}\right)$. HRMS calculated for $\mathrm{C}_{19} \mathrm{H}_{27} \mathrm{~N}_{6} \mathrm{O}_{2}[\mathrm{M}+\mathrm{H}]^{+}:$371.21955; found: 371.21900 . [ $\left.\alpha\right]_{\mathrm{D}}:-24.7^{\circ}(7.5 \mathrm{mg} / \mathrm{ml}, \mathrm{MeOH})$.

Compound (6f). Following the general procedure for CuAAC, starting from compound 4 (80 $\mathrm{mg}, 0.28 \mathrm{mmol}$ ) and compound $\mathbf{5 f}(70 \mathrm{mg}, 0.56 \mathrm{mmol})$, and using DCM/MeOH (96/4) as eluent for flash chromatography purification, compound $\mathbf{6 f}$ was obtained as a colorless oil (104 mg, 90\%). ${ }^{1} \mathrm{H}$ NMR (500 MHz, $\left.\mathrm{CDCl}_{3}\right) \delta 7.61\left(\mathrm{~s}, 1 \mathrm{H}, \mathrm{H}_{8}\right), 7.37-7.28\left(\mathrm{~m}, 5 \mathrm{H}, \mathrm{H}_{15,16,17}\right), 4.96(\mathrm{~d}, J$ $\left.=11.5 \mathrm{~Hz}, 1 \mathrm{H}, \mathrm{H}_{13}\right), 4.83\left(\mathrm{~d}, J=11.5 \mathrm{~Hz}, 1 \mathrm{H}, \mathrm{H}_{13}\right), 4.49\left(\mathrm{dd}, J=14.2,8.1 \mathrm{~Hz}, 1 \mathrm{H}, \mathrm{H}_{7}\right), 4.44$ $\left(\mathrm{dd}, J=14.2,6.9 \mathrm{~Hz}, 1 \mathrm{H}, \mathrm{H}_{7}\right), 3.78-3.73\left(\mathrm{~m}, 1 \mathrm{H}, \mathrm{H}_{1}\right), 3.64\left(\mathrm{t}, J=4.7 \mathrm{~Hz}, 4 \mathrm{H}, \mathrm{H}_{12}\right), 3.60(\mathrm{~s}, 2 \mathrm{H}$, $\left.\mathrm{H}_{10}\right), 3.33\left(\mathrm{bs}, 1 \mathrm{H}, \mathrm{H}_{4}\right), 2.88\left(\mathrm{~s}, 2 \mathrm{H}, \mathrm{H}_{5}\right), 2.45\left(\mathrm{t}, J=4.7 \mathrm{~Hz}, 4 \mathrm{H}, \mathrm{H}_{11}\right), 2.03-1.98\left(\mathrm{~m}, 1 \mathrm{H}, \mathrm{H}_{3}\right)$, 1.95-1.87 (m, 1H, $\left.\mathrm{H}_{2}\right), 1.66-1.60\left(\mathrm{~m}, 1 \mathrm{H}, \mathrm{H}_{3}\right), 1.54-1.48\left(\mathrm{~m}, 1 \mathrm{H}, \mathrm{H}_{2}\right) .{ }^{13} \mathrm{C} \mathrm{NMR}(125 \mathrm{MHz}$, $\left.\mathrm{CDCl}_{3}\right) \delta 169.3\left(\mathrm{C}_{6}\right), 144.5\left(\mathrm{C}_{9}\right), 135.7\left(\mathrm{C}_{14}\right), 129.2\left(2 \mathrm{C}, \mathrm{C}_{15}\right), 128.7\left(\mathrm{C}_{17}\right), 128.5\left(2 \mathrm{C}, \mathrm{C}_{16}\right)$, $123.0\left(\mathrm{C}_{8}\right), 78.2\left(\mathrm{C}_{13}\right), 66.8\left(2 \mathrm{C}, \mathrm{C}_{12}\right), 58.2\left(\mathrm{C}_{4}\right), 56.7\left(\mathrm{C}_{1}\right), 53.6\left(\mathrm{C}_{10}\right), 53.4\left(2 \mathrm{C}, \mathrm{C}_{11}\right), 51.7\left(\mathrm{C}_{7}\right)$, $43.7\left(\mathrm{C}_{5}\right), 20.3\left(\mathrm{C}_{2}\right), 19.6\left(\mathrm{C}_{3}\right)$. HRMS calculated for $\mathrm{C}_{21} \mathrm{H}_{29} \mathrm{~N}_{6} \mathrm{O}_{3}[\mathrm{M}+\mathrm{H}]^{+}$: 413.22957; found: 413.22753. $[\alpha]_{\mathrm{D}}:-17.3^{\circ}(4.4 \mathrm{mg} / \mathrm{ml}, \mathrm{MeOH})$.

Compound (6g). Following the general procedure for $\mathrm{CuAAC}$, starting from compound 4 (200 mg, $0.70 \mathrm{mmol}$ ) and compound $\mathbf{5 g}$ (217 mg, $1.40 \mathrm{mmol})$, and using cyclohexane/ethyl acetate (1/9) as eluent for flash chromatography purification, compound $\mathbf{6} \mathbf{g}$ was obtained as a colorless oil (289 mg, 93\%). ${ }^{1} \mathrm{H} \mathrm{NMR}\left(500 \mathrm{MHz}, \mathrm{CDCl}_{3}\right) \delta 7.62\left(\mathrm{~s}, 1 \mathrm{H}, \mathrm{H}_{8}\right), 7.39-7.30(\mathrm{~m}, 5 \mathrm{H}$, 
$\left.\mathrm{H}_{16,17,18}\right), 4.98\left(\mathrm{~d}, J=11.5 \mathrm{~Hz}, 1 \mathrm{H}, \mathrm{H}_{14}\right), 4.84\left(\mathrm{~d}, J=11.5 \mathrm{~Hz}, 1 \mathrm{H}, \mathrm{H}_{14}\right), 4.51(\mathrm{dd}, J=14.2,8.1$ $\left.\mathrm{Hz}, 1 \mathrm{H}, \mathrm{H}_{7}\right), 4.44\left(\mathrm{dd}, J=14.2,6.9 \mathrm{~Hz}, 1 \mathrm{H}, \mathrm{H}_{7}\right), 4.34\left(\mathrm{~d}, J=5.9 \mathrm{~Hz}, 2 \mathrm{H}, \mathrm{H}_{10}\right), 3.79-3.74(\mathrm{~m}$, $\left.1 \mathrm{H}, \mathrm{H}_{1}\right), 3.33$ (bs, $\left.1 \mathrm{H}, \mathrm{H}_{4}\right), 2.89$ (s, 2H, $\left.\mathrm{H}_{5}\right), 2.05-1.99$ (m, 1H, $\left.\mathrm{H}_{3}\right), 1.97-1.89$ (m, 1H, $\left.\mathrm{H}_{2}\right), 1.67-$ $1.60\left(\mathrm{~m}, 1 \mathrm{H}, \mathrm{H}_{3}\right), 1.54-1.48\left(\mathrm{~m}, 1 \mathrm{H}, \mathrm{H}_{2}\right), 1.41\left(\mathrm{~s}, 9 \mathrm{H}, \mathrm{H}_{13}\right) .{ }^{13} \mathrm{C} \mathrm{NMR}\left(125 \mathrm{MHz}, \mathrm{CDCl}_{3}\right) \delta$ $169.3\left(\mathrm{C}_{6}\right), 155.9\left(\mathrm{C}_{11}\right), 145.9\left(\mathrm{C}_{9}\right), 135.8\left(\mathrm{C}_{15}\right), 129.3\left(2 \mathrm{C}, \mathrm{C}_{16}\right), 128.8\left(\mathrm{C}_{18}\right), 128.6\left(2 \mathrm{C}, \mathrm{C}_{17}\right)$, $122.3\left(\mathrm{C}_{8}\right), 79.7\left(\mathrm{C}_{12}\right), 78.2\left(\mathrm{C}_{14}\right), 58.3\left(\mathrm{C}_{4}\right), 56.7\left(\mathrm{C}_{1}\right), 51.7\left(\mathrm{C}_{7}\right), 43.8\left(\mathrm{C}_{5}\right), 36.3\left(\mathrm{C}_{10}\right), 28.4$ (3C, $\left.\mathrm{C}_{13}\right), 20.3\left(\mathrm{C}_{2}\right), 19.7\left(\mathrm{C}_{3}\right)$. HRMS calculated for $\mathrm{C}_{22} \mathrm{H}_{31} \mathrm{~N}_{6} \mathrm{O}_{4}[\mathrm{M}+\mathrm{H}]^{+}$: 443.24068; found: 443.23941. $[\alpha]_{\mathrm{D}}:-20.5^{\circ}(5.4 \mathrm{mg} / \mathrm{ml}, \mathrm{MeOH})$.

Compound (6h). Following the general procedure for CuAAC, starting from compound 4 (200 $\mathrm{mg}, 0.70 \mathrm{mmol}$ ) and 1-boc-4-ethynylpiperidine $\mathbf{5 h}$ (293 $\mathrm{mg}, 1.40 \mathrm{mmol})$, and using DCM/MeOH (96/4) as eluent for flash chromatography purification, compound $\mathbf{6 h}$ was obtained as a colorless oil (336 mg, 97\%). ${ }^{1} \mathrm{H}$ NMR $\left(500 \mathrm{MHz}, \mathrm{CDCl}_{3}\right) \delta$ 7.37-7.27 (m, 5H, $\left.\mathrm{H}_{18,19,20}\right), 4.96\left(\mathrm{~d}, J=11.5 \mathrm{~Hz}, 1 \mathrm{H}, \mathrm{H}_{16}\right), 4.82\left(\mathrm{~d}, J=11.5 \mathrm{~Hz}, 1 \mathrm{H}, \mathrm{H}_{16}\right), 4.49$ (bs, 2H, H7), 4.10

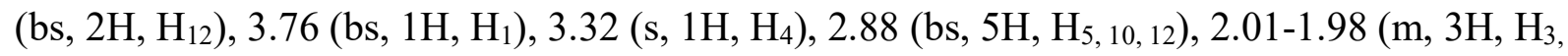
11), 1.94-1.87 (m, $\left.1 \mathrm{H}, \mathrm{H}_{2}\right), 1.68-1.62\left(\mathrm{~m}, 1 \mathrm{H}, \mathrm{H}_{3}\right), 1.57-1.51\left(\mathrm{~m}, 3 \mathrm{H}, \mathrm{H}_{2,11}\right), 1.42\left(\mathrm{~s}, 9 \mathrm{H}, \mathrm{H}_{15}\right) * H_{8}$ not visible on the ${ }^{1} H$ NMR spectrum. ${ }^{13} \mathrm{C}$ NMR $\left(125 \mathrm{MHz}, \mathrm{CDCl}_{3}\right) \delta 169.2\left(\mathrm{C}_{6}\right), 154.7\left(\mathrm{C}_{13}\right)$, $135.7\left(\mathrm{C}_{17}\right), 129.1\left(2 \mathrm{C}, \mathrm{C}_{18}\right), 128.7\left(\mathrm{C}_{20}\right), 128.5\left(2 \mathrm{C}, \mathrm{C}_{19}\right), 79.4\left(\mathrm{C}_{14}\right), 78.1\left(\mathrm{C}_{16}\right), 58.3\left(\mathrm{C}_{4}\right), 56.5$ $\left(\mathrm{C}_{1}\right), 52.1\left(\mathrm{C}_{7}\right), 43.6\left(3 \mathrm{C}, \mathrm{C}_{5}\right.$ and $\left.\mathrm{C}_{12}\right), 33.6\left(\mathrm{C}_{10}\right), 31.4\left(2 \mathrm{C}, \mathrm{C}_{11}\right), 28.4\left(3 \mathrm{C}, \mathrm{C}_{15}\right), 20.4\left(\mathrm{C}_{2}\right), 19.6$ $\left(\mathrm{C}_{3}\right) * C_{8}$ and $C_{9}$ not visible on the ${ }^{13} C$ NMR spectrum. HRMS calculated for $\mathrm{C}_{26} \mathrm{H}_{37} \mathrm{~N}_{6} \mathrm{O}_{4}$ $[\mathrm{M}+\mathrm{H}]^{+}:$497.28763; found: 497.28723. $[\alpha]_{\mathrm{D}}:-6.3^{\circ}(6.3 \mathrm{mg} / \mathrm{ml}, \mathrm{MeOH})$.

Compound (6i). Following the general procedure for CuAAC, starting from compound 4 (90 $\mathrm{mg}, 0.31 \mathrm{mmol})$ and $\mathbf{5 i}(181 \mathrm{mg}, 0.63 \mathrm{mmol})$ and using DCM/MeOH (96/4) as eluent for flash chromatography purification, compound 6i was obtained as a pale yellow solid (163 mg, 91\%). ${ }^{1} \mathrm{H}$ NMR (500 MHz, $\left.\mathrm{CDCl}_{3}\right) \delta 8.35(\mathrm{bd}, J=12.5 \mathrm{~Hz}, 1 \mathrm{H}, \mathrm{NH}), 7.85\left(\mathrm{~s}, 1 \mathrm{H}, \mathrm{H}_{8}\right), 7.68(\mathrm{~d}, J=$

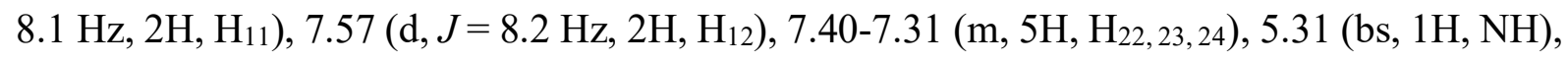


$5.00\left(\mathrm{~d}, J=11.5 \mathrm{~Hz}, 1 \mathrm{H}, \mathrm{H}_{20}\right), 4.86\left(\mathrm{~d}, J=11.5 \mathrm{~Hz}, 1 \mathrm{H}, \mathrm{H}_{20}\right), 4.56(\mathrm{dd}, J=14.2,8.0 \mathrm{~Hz}, 1 \mathrm{H}$, $\left.\mathrm{H}_{7}\right), 4.50\left(\mathrm{dd}, J=14.3,6.9 \mathrm{~Hz}, 1 \mathrm{H}, \mathrm{H}_{7}\right), 3.86-3.81\left(\mathrm{~m}, 1 \mathrm{H}, \mathrm{H}_{1}\right), 3.49-3.45\left(\mathrm{~m}, 2 \mathrm{H}, \mathrm{H}_{16}\right), 3.35$ (bs, 1H, $\left.\mathrm{H}_{4}\right), 2.94\left(\mathrm{~s}, 2 \mathrm{H}, \mathrm{H}_{5}\right), 2.60$ (t, $\left.J=5.5 \mathrm{~Hz}, 2 \mathrm{H}, \mathrm{H}_{15}\right), 2.07-2.02\left(\mathrm{~m}, 1 \mathrm{H}, \mathrm{H}_{3}\right), 2.00-1.92$ $\left(\mathrm{m}, 1 \mathrm{H}, \mathrm{H}_{2}\right), 1.71-1.64\left(\mathrm{~m}, 1 \mathrm{H}, \mathrm{H}_{3}\right), 1.60-1.54\left(\mathrm{~m}, 1 \mathrm{H}, \mathrm{H}_{2}\right), 1.42\left(\mathrm{~s}, 9 \mathrm{H}, \mathrm{H}_{19}\right) .{ }^{13} \mathrm{C}$ NMR $(125$ $\left.\mathrm{MHz}, \mathrm{CDCl}_{3}\right) \delta 170.1\left(\mathrm{C}_{14}\right), 169.5\left(\mathrm{C}_{6}\right), 156.5\left(\mathrm{C}_{17}\right), 147.8\left(\mathrm{C}_{9}\right), 138.2\left(\mathrm{C}_{10}\right), 135.7\left(\mathrm{C}_{21}\right), 129.3$ (2C, $\left.\mathrm{C}_{22}\right), 128.9\left(\mathrm{C}_{24}\right), 128.7\left(2 \mathrm{C}, \mathrm{C}_{23}\right), 126.4\left(3 \mathrm{C}, \mathrm{C}_{11}\right.$ and $\left.\mathrm{C}_{13}\right), 120.2\left(2 \mathrm{C}, \mathrm{C}_{12}\right), 119.9\left(\mathrm{C}_{8}\right)$, $79.7\left(\mathrm{C}_{18}\right), 78.3\left(\mathrm{C}_{20}\right), 58.4\left(\mathrm{C}_{4}\right), 56.7\left(\mathrm{C}_{1}\right), 51.9\left(\mathrm{C}_{7}\right), 43.9\left(\mathrm{C}_{5}\right), 37.6\left(\mathrm{C}_{15}\right), 36.6\left(\mathrm{C}_{16}\right), 28.5(3 \mathrm{C}$, $\left.\mathrm{C}_{19}\right), 20.3\left(\mathrm{C}_{2}\right), 19.8\left(\mathrm{C}_{3}\right)$. HRMS calculated for $\mathrm{C}_{30} \mathrm{H}_{38} \mathrm{~N}_{7} \mathrm{O}_{5}[\mathrm{M}+\mathrm{H}]^{+}$: 576.29344; found: 576.29582. $[\alpha]_{\mathrm{D}}:-13.5^{\circ}(4.0 \mathrm{mg} / \mathrm{ml}, \mathrm{MeOH})$.

Compound (6j). Following the general procedure for CuAAC, starting from compound 4 (200 $\mathrm{mg}, 0.70 \mathrm{mmol}$ ) and 4-pentynoic acid 5j (137 mg, $1.40 \mathrm{mmol})$, and using DCM/MeOH (9/1) as eluent for flash chromatography purification, compound $\mathbf{6 j}$ was obtained as a pale yellow solid (202 mg, 75\%). ${ }^{1} \mathrm{H}$ NMR (500 MHz, $\left.\mathrm{CDCl}_{3}\right) \delta 7.57$ (s, 1H, $\left.\mathrm{H}_{8}\right), 7.41-7.33\left(\mathrm{~m}, 5 \mathrm{H}, \mathrm{H}_{15}, 16\right.$, 17), $5.01\left(\mathrm{~d}, J=11.5 \mathrm{~Hz}, 1 \mathrm{H}, \mathrm{H}_{13}\right), 4.87\left(\mathrm{~d}, J=11.5 \mathrm{~Hz}, 1 \mathrm{H}, \mathrm{H}_{13}\right), 4.53-4.44\left(\mathrm{~m}, 2 \mathrm{H}, \mathrm{H}_{7}\right), 3.82-$ $3.77\left(\mathrm{~m}, 1 \mathrm{H}, \mathrm{H}_{1}\right), 3.35\left(\mathrm{bd}, J=2.8 \mathrm{~Hz}, 1 \mathrm{H}, \mathrm{H}_{4}\right), 3.03\left(\mathrm{t}, J=6.4 \mathrm{~Hz}, 2 \mathrm{H}, \mathrm{H}_{10}\right), 2.95-2.88(\mathrm{~m}, 2 \mathrm{H}$, $\left.\mathrm{H}_{5}\right), 2.75\left(\mathrm{t}, J=6.2 \mathrm{~Hz}, 2 \mathrm{H}, \mathrm{H}_{11}\right), 2.07-2.01\left(\mathrm{~m}, 1 \mathrm{H}, \mathrm{H}_{3}\right), 1.94\left(\mathrm{dq}, J=15.1,7.5 \mathrm{~Hz}, 1 \mathrm{H}, \mathrm{H}_{2}\right)$, 1.69-1.63 (m, 1H, $\left.\mathrm{H}_{3}\right), 1.58-1.52\left(\mathrm{~m}, 1 \mathrm{H}, \mathrm{H}_{2}\right) .{ }^{13} \mathrm{C} \mathrm{NMR}\left(125 \mathrm{MHz}, \mathrm{CDCl}_{3}\right) \delta 175.8\left(\mathrm{C}_{12}\right), 169.5$ $\left(\mathrm{C}_{6}\right), 146.8\left(\mathrm{C}_{9}\right), 135.8\left(\mathrm{C}_{14}\right), 129.4\left(2 \mathrm{C}, \mathrm{C}_{15}\right), 128.9\left(\mathrm{C}_{17}\right), 128.7\left(2 \mathrm{C}, \mathrm{C}_{16}\right), 122.0\left(\mathrm{C}_{8}\right), 78.4$ $\left(\mathrm{C}_{13}\right), 58.4\left(\mathrm{C}_{4}\right), 56.7\left(\mathrm{C}_{1}\right), 51.9\left(\mathrm{C}_{7}\right), 43.9\left(\mathrm{C}_{5}\right), 33.5\left(\mathrm{C}_{11}\right), 21.0\left(\mathrm{C}_{10}\right), 20.3\left(\mathrm{C}_{2}\right), 19.8\left(\mathrm{C}_{3}\right)$. HRMS calculated for $\mathrm{C}_{19} \mathrm{H}_{24} \mathrm{~N}_{5} \mathrm{O}_{4}[\mathrm{M}+\mathrm{H}]^{+}:$386.18283; found: 386.18228 . [ $\left.\alpha\right]_{\mathrm{D}}:-23.8^{\circ}(7.9$ $\mathrm{mg} / \mathrm{ml}, \mathrm{MeOH})$

Compound (7a). Following the general procedure for the introduction of sodium sulphite, compound $7 \mathbf{a}$ was obtained as a white powder (18 mg, 21\%) starting from compound $6 \mathbf{a}$ (83 mg, $0.21 \mathrm{mmol}) .{ }^{1} \mathrm{H}$ NMR (500 MHz, $\left.\mathrm{D}_{2} \mathrm{O}\right) \delta 8.81$ (bs, $\left.1 \mathrm{H}, \mathrm{H}_{14}\right), 8.50$ (bd, $\left.J=4.8 \mathrm{~Hz}, 1 \mathrm{H}, \mathrm{H}_{13}\right)$, $8.44\left(\mathrm{~s}, 1 \mathrm{H}, \mathrm{H}_{8}\right), 8.12\left(\mathrm{bd}, J=8.0 \mathrm{~Hz}, 1 \mathrm{H}, \mathrm{H}_{11}\right), 7.52\left(\mathrm{dd}, J=7.9,5.0 \mathrm{~Hz}, 1 \mathrm{H}, \mathrm{H}_{12}\right), 4.97$ (dd, $J$ 
$\left.=14.8,10.6 \mathrm{~Hz}, 1 \mathrm{H}, \mathrm{H}_{7}\right), 4.71\left(\mathrm{dd}, J=14.8,5.6 \mathrm{~Hz}, 1 \mathrm{H}, \mathrm{H}_{7}\right), 4.31-4.29\left(\mathrm{~m}, 1 \mathrm{H}, \mathrm{H}_{4}\right), 4.01-3.96$ $\left(\mathrm{m}, 1 \mathrm{H}, \mathrm{H}_{1}\right), 3.56\left(\mathrm{~d}, J=12.3 \mathrm{~Hz}, 1 \mathrm{H}, \mathrm{H}_{5}\right), 3.24\left(\mathrm{bd}, J=12.2 \mathrm{~Hz}, 1 \mathrm{H}, \mathrm{H}_{5}\right), 2.18-2.12(\mathrm{~m}, 1 \mathrm{H}$, $\left.\mathrm{H}_{3}\right), 2.09-1.99\left(\mathrm{~m}, 2 \mathrm{H}, \mathrm{H}_{2,3}\right), 1.81-1.74\left(\mathrm{~m}, 1 \mathrm{H}, \mathrm{H}_{2}\right) .{ }^{13} \mathrm{C} \mathrm{NMR}\left(125 \mathrm{MHz}, \mathrm{D}_{2} \mathrm{O}\right) \delta 170.2\left(\mathrm{C}_{6}\right)$, $148.3\left(\mathrm{C}_{13}\right), 145.5\left(\mathrm{C}_{14}\right), 144.3\left(\mathrm{C}_{9}\right), 134.1\left(\mathrm{C}_{11}\right), 126.1\left(\mathrm{C}_{10}\right), 124.5\left(\mathrm{C}_{12}\right), 122.8\left(\mathrm{C}_{8}\right), 60.1\left(\mathrm{C}_{4}\right)$, $57.9\left(\mathrm{C}_{1}\right), 50.8\left(\mathrm{C}_{7}\right), 43.6\left(\mathrm{C}_{5}\right), 19.8\left(\mathrm{C}_{2}\right), 18.8\left(\mathrm{C}_{3}\right)$. HRMS calculated for $\mathrm{C}_{14} \mathrm{H}_{14} \mathrm{~N}_{6} \mathrm{O}_{5} \mathrm{~S}[\mathrm{M}-\mathrm{H}]^{-}$ : 379.08246; found: 379.08392. $[\alpha]_{\mathrm{D}}:-44.6^{\circ}(9.1 \mathrm{mg} / \mathrm{ml}, \mathrm{MeOH}) . \mathrm{HPLC}$ purity $=98.7 \%$; $\mathrm{rt}=$ $9.4 \mathrm{~min}\left(\mathrm{CH}_{3} \mathrm{CN} / \mathrm{H}_{2} \mathrm{O} \quad 0: 100\right.$ to $100: 0$ over $\left.15 \mathrm{~min}\right)$.

Compound (7b). Following the general procedure for the introduction of sodium sulphite, compound $7 \mathbf{b}$ was obtained as a white powder (44 mg, 19\%) starting from compound $\mathbf{6 b}$ (226 mg, $0.58 \mathrm{mmol}) .{ }^{1} \mathrm{H}$ NMR (500 MHz, $\left.\mathrm{D}_{2} \mathrm{O}\right) \delta 8.28\left(\mathrm{~s}, 1 \mathrm{H}, \mathrm{H}_{8}\right), 7.77\left(\mathrm{~d}, J=7.3 \mathrm{~Hz}, 2 \mathrm{H}, \mathrm{H}_{11}\right)$, $7.53\left(\mathrm{t}, J=7.3 \mathrm{~Hz}, 2 \mathrm{H}, \mathrm{H}_{12}\right), 7.46\left(\mathrm{~d}, J=7.3 \mathrm{~Hz}, 1 \mathrm{H}, \mathrm{H}_{13}\right), 4.86\left(\mathrm{dd}, J=14.8,10.2 \mathrm{~Hz}, 1 \mathrm{H}, \mathrm{H}_{7}\right)$, $4.62\left(\mathrm{dd}, J=14.7,5.7 \mathrm{~Hz}, 1 \mathrm{H}, \mathrm{H}_{7}\right), 4.30-4.28\left(\mathrm{~m}, 1 \mathrm{H}, \mathrm{H}_{4}\right), 3.95-3.91\left(\mathrm{~m}, 1 \mathrm{H}, \mathrm{H}_{1}\right), 3.50(\mathrm{~d}, J=$ $\left.12.3 \mathrm{~Hz}, 1 \mathrm{H}, \mathrm{H}_{5}\right), 3.22\left(\mathrm{bd}, \mathrm{J}=12.2 \mathrm{~Hz}, 1 \mathrm{H}, \mathrm{H}_{5}\right), 2.15-2.09\left(\mathrm{~m}, 1 \mathrm{H}, \mathrm{H}_{3}\right), 2.04-1.95\left(\mathrm{~m}, 2 \mathrm{H}, \mathrm{H}_{2}\right.$, 3), 1.77-1.68 (m, 1H, H2). ${ }^{13} \mathrm{C}$ NMR (125 MHz, $\left.\mathrm{D}_{2} \mathrm{O}\right) \delta 170.1\left(\mathrm{C}_{6}\right), 147.6\left(\mathrm{C}_{9}\right), 129.4\left(\mathrm{C}_{10}\right)$, $129.2\left(2 \mathrm{C}, \mathrm{C}_{12}\right), 128.8\left(\mathrm{C}_{13}\right), 125.6\left(2 \mathrm{C}, \mathrm{C}_{11}\right), 122.3\left(\mathrm{C}_{8}\right), 60.1\left(\mathrm{C}_{4}\right), 57.8\left(\mathrm{C}_{1}\right), 50.8\left(\mathrm{C}_{7}\right), 43.6$ $\left(\mathrm{C}_{5}\right), 19.7\left(\mathrm{C}_{2}\right), 18.8\left(\mathrm{C}_{3}\right)$. HRMS calculated for $\left.\mathrm{C}_{15} \mathrm{H}_{16} \mathrm{~N}_{5} \mathrm{O}_{5} \mathrm{~S}[\mathrm{M}-\mathrm{H}]\right]^{-}: 378.08721$; found: 378.08804. $[\alpha]_{\mathrm{D}}:-36.7^{\circ}\left(10.7 \mathrm{mg} / \mathrm{ml}, \mathrm{H}_{2} \mathrm{O}\right) . \mathrm{HPLC}$ purity $=98.1 \% ; \mathrm{rt}=10.4 \mathrm{~min}\left(\mathrm{CH}_{3} \mathrm{CN} / \mathrm{H}_{2} \mathrm{O}\right.$ 0:100 to $100: 0$ over $15 \mathrm{~min})$.

Compound (7c). Following the general procedure for the introduction of sodium sulphite, compound $7 \mathbf{c}$ was obtained as a white powder (12 mg, 14\%) starting from compound $\mathbf{6 c}$ (82 mg, $0.21 \mathrm{mmol}) .{ }^{1} \mathrm{H}$ NMR $\left(500 \mathrm{MHz}, \mathrm{D}_{2} \mathrm{O}\right) \delta 8.15\left(\mathrm{~s}, 1 \mathrm{H}, \mathrm{H}_{8}\right), 4.95(\mathrm{dd}, J=14.7,10.0 \mathrm{~Hz}, 1 \mathrm{H}$, $\left.\mathrm{H}_{7}\right), 4.72\left(\mathrm{dd}, J=14.7,5.9 \mathrm{~Hz}, 1 \mathrm{H}, \mathrm{H}_{7}\right), 4.29-4.28\left(\mathrm{~m}, 1 \mathrm{H}, \mathrm{H}_{4}\right), 3.97-3.92\left(\mathrm{~m}, 1 \mathrm{H}, \mathrm{H}_{1}\right), 3.50(\mathrm{~d}$, $\left.J=12.3 \mathrm{~Hz}, 1 \mathrm{H}, \mathrm{H}_{5}\right), 3.23-3.20\left(\mathrm{~m}, 1 \mathrm{H}, \mathrm{H}_{5}\right), 2.17-2.09\left(\mathrm{~m}, 1 \mathrm{H}, \mathrm{H}_{3}\right), 2.05-1.96\left(\mathrm{~m}, 2 \mathrm{H}, \mathrm{H}_{2,3}\right)$, 1.76-1.69 (m, 1H, $\left.\mathrm{H}_{2}\right), 0.35\left(\mathrm{~s}, 9 \mathrm{H}, \mathrm{H}_{10}\right) .{ }^{13} \mathrm{C} \mathrm{NMR}\left(125 \mathrm{MHz}, \mathrm{D}_{2} \mathrm{O}\right) \delta 170.2\left(\mathrm{C}_{6}\right), 147.7\left(\mathrm{C}_{9}\right)$, 131.4 $\left(\mathrm{C}_{8}\right), 60.0\left(\mathrm{C}_{4}\right), 57.9\left(\mathrm{C}_{1}\right), 50.1\left(\mathrm{C}_{7}\right), 43.6\left(\mathrm{C}_{5}\right), 19.6\left(\mathrm{C}_{2}\right), 18.8\left(\mathrm{C}_{3}\right),-2.3\left(3 \mathrm{C}_{1} \mathrm{C}_{10}\right)$. HRMS 
calculated for $\mathrm{C}_{12} \mathrm{H}_{19} \mathrm{~N}_{5} \mathrm{O}_{5} \mathrm{SSi}[\mathrm{M}-\mathrm{H}]^{-}: 374.09544$; found: 374.09427 . [ $\left.\alpha\right]_{\mathrm{D}}:-52.0^{\circ}(2.0 \mathrm{mg} / \mathrm{ml}$, $\mathrm{MeOH}) . \mathrm{HPLC}$ purity $=96.1 \%$; $\mathrm{rt}=10.6 \mathrm{~min}\left(\mathrm{CH}_{3} \mathrm{CN} / \mathrm{H}_{2} \mathrm{O}\right.$ 0:100 to 100:0 over $\left.15 \mathrm{~min}\right)$.

Compound (7d). Following the general procedure for the introduction of sodium sulphite, compound 7d was obtained as a colorless foam (28 mg, 13\%) starting from compound $\mathbf{6 d}$ (210 mg, $0.59 \mathrm{mmol}) .{ }^{1} \mathrm{H}$ NMR (500 MHz, $\left.\mathrm{D}_{2} \mathrm{O}\right) \delta 8.18\left(\mathrm{~s}, 1 \mathrm{H}, \mathrm{H}_{8}\right), 4.96(\mathrm{dd}, J=14.8,10.3 \mathrm{~Hz}, 1 \mathrm{H}$, $\left.\mathrm{H}_{7}\right), 4.73\left(\mathrm{dd}, J=14.8,5.7 \mathrm{~Hz}, 1 \mathrm{H}, \mathrm{H}_{7}\right), 4.68\left(\mathrm{~s}, 2 \mathrm{H}, \mathrm{H}_{10}\right), 4.32-4.30\left(\mathrm{~m}, 1 \mathrm{H}, \mathrm{H}_{4}\right), 4.00-3.95(\mathrm{~m}$, $\left.1 \mathrm{H}, \mathrm{H}_{1}\right), 3.55\left(\mathrm{~d}, J=12.3 \mathrm{~Hz}, 1 \mathrm{H}, \mathrm{H}_{5}\right), 3.45$ (s, 3H, $\left.\mathrm{H}_{11}\right), 3.25$ (bd, $\left.J=12.3 \mathrm{~Hz}, 1 \mathrm{H}, \mathrm{H}_{5}\right), 2.19$ $2.13\left(\mathrm{~m}, 1 \mathrm{H}, \mathrm{H}_{3}\right), 2.08-1.99\left(\mathrm{~m}, 2 \mathrm{H}, \mathrm{H}_{2,3}\right), 1.80-1.76\left(\mathrm{~m}, 1 \mathrm{H}, \mathrm{H}_{2}\right) .{ }^{13} \mathrm{C} \mathrm{NMR}\left(125 \mathrm{MHz}, \mathrm{D}_{2} \mathrm{O}\right)$ $\delta 170.1\left(\mathrm{C}_{6}\right), 144.0\left(\mathrm{C}_{9}\right), 125.4\left(\mathrm{C}_{8}\right), 64.4\left(\mathrm{C}_{10}\right), 60.1\left(\mathrm{C}_{4}\right), 57.9\left(\mathrm{C}_{1}\right), 57.5\left(\mathrm{C}_{11}\right), 50.7\left(\mathrm{C}_{7}\right), 43.6$ $\left(\mathrm{C}_{5}\right), 19.7\left(\mathrm{C}_{2}\right), 18.8\left(\mathrm{C}_{3}\right)$. HRMS calculated for $\mathrm{C}_{11} \mathrm{H}_{16} \mathrm{~N}_{5} \mathrm{O}_{6} \mathrm{~S}[\mathrm{M}-\mathrm{H}]^{-}:$: 346.08213; found: 346.08185. HPLC purity $=98.3 \% ; \mathrm{rt}=13.5 \mathrm{~min}\left(\mathrm{CH}_{3} \mathrm{CN}+0.1 \%\right.$ TFA $/ \mathrm{H}_{2} \mathrm{O}+0.1 \%$ TFA 0:100 to $100: 0$ over $30 \mathrm{~min})$.

Compound (7e). Starting from compound $\mathbf{6 e}(173 \mathrm{mg}, 0.47 \mathrm{mmol})$ and following the general procedure for the introduction of sodium sulphite, product $7 \mathbf{e}$ was obtained as a white powder (32 mg, 18\%) in the form of a mixture of two isomers. ${ }^{1} \mathrm{H}$ NMR $\left(500 \mathrm{MHz}, \mathrm{D}_{2} \mathrm{O}\right) \delta 8.50(\mathrm{~s}$, 0,5H, $\left.\mathrm{H}_{8}\right), 8.38\left(\mathrm{~s}, 0,5 \mathrm{H}, \mathrm{H}_{8}{ }^{\prime}\right), 5.03-4.96\left(\mathrm{~m}, 1 \mathrm{H}, \mathrm{H}_{7}, 7^{\prime}\right), 4.77-4.72\left(\mathrm{~m}, 1 \mathrm{H}, \mathrm{H}_{7}, 7^{\prime}\right), 4.71(\mathrm{~s}, 1 \mathrm{H}$, $\left.\mathrm{H}_{10}\right), 4.52\left(\mathrm{~s}, 1 \mathrm{H}, \mathrm{H}_{10^{\prime}}\right), 4.30$ (bs, $\left.\left.1 \mathrm{H}, \mathrm{H}_{4}, 4^{\prime}\right), 3.99-3.93\left(\mathrm{~m}, 1 \mathrm{H}, \mathrm{H}_{1,1}\right)^{\prime}\right), 3.57$ (dd, $J=12.3,7.8$ Hz, 1H, $\mathrm{H}_{5,5}$ ), 3.23 (bd, $J=12.3 \mathrm{~Hz}, 1 \mathrm{H}, \mathrm{H}_{5,5}$ ), 3.19 (s, 3H, H $\mathrm{H}_{11}$ ), 2.94 (s, 3H, $\mathrm{H}_{11^{\prime}}$ ), 2.15-2.10

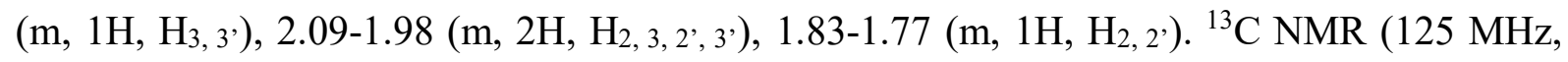
$\left.\mathrm{D}_{2} \mathrm{O}\right) \delta 170.1\left(2 \mathrm{C}_{1} \mathrm{C}_{6}\right.$ and $\left.\mathrm{C}_{6}{ }^{\prime}\right), 136.7\left(\mathrm{C}_{9}\right), 135.6\left(\mathrm{C}_{9}\right), 129.1\left(\mathrm{C}_{8}\right), 127.7\left(\mathrm{C}_{8}\right), 60.1\left(\mathrm{C}_{10}\right), 59.8$

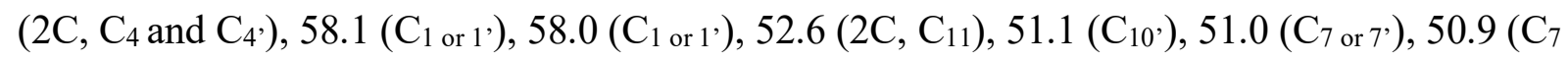
or $\left.7^{\prime}\right), 43.4\left(2 \mathrm{C}, \mathrm{C}_{5}\right.$ and $\left.\mathrm{C}_{5^{\prime}}\right), 42.2\left(2 \mathrm{C}, \mathrm{C}_{11^{\prime}}\right), 19.9\left(\mathrm{C}_{2}\right.$ or $\left.2^{\prime}\right), 19.8\left(\mathrm{C}_{2}\right.$ or $\left.2^{\prime}\right), 18.8\left(2 \mathrm{C}, \mathrm{C}_{3}\right.$ and $\left.\mathrm{C}_{3^{\prime}}\right)$.

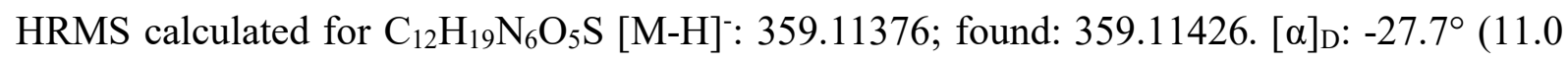
$\left.\mathrm{mg} / \mathrm{ml}, \mathrm{H}_{2} \mathrm{O}\right)$. HPLC purity $=98.1 \% ; \mathrm{rt}=6.8 \mathrm{~min}\left(\mathrm{CH}_{3} \mathrm{CN} / \mathrm{H}_{2} \mathrm{O}\right.$ 0:100 to 100:0 over $\left.15 \mathrm{~min}\right)$. 
Compound (7f). Following the general procedure for the introduction of sodium sulphite, compound $7 \mathbf{f}$ was obtained as a white powder $(6 \mathrm{mg}, 8 \%)$ starting from compound $\mathbf{6 f}$ (74 $\mathrm{mg}$, $0.18 \mathrm{mmol}) .{ }^{1} \mathrm{H}$ NMR $\left(500 \mathrm{MHz}, \mathrm{D}_{2} \mathrm{O}\right) \delta 8.12\left(\mathrm{~s}, 1 \mathrm{H}, \mathrm{H}_{8}\right), 4.95\left(\mathrm{dd}, J=14.7,10.3 \mathrm{~Hz}, 1 \mathrm{H}, \mathrm{H}_{7}\right)$, $4.71\left(\mathrm{dd}, J=14.7,5.7 \mathrm{~Hz}, 1 \mathrm{H}, \mathrm{H}_{7}\right), 4.31-4.30\left(\mathrm{~m}, 1 \mathrm{H}, \mathrm{H}_{4}\right), 3.99-3.94\left(\mathrm{~m}, 1 \mathrm{H}, \mathrm{H}_{1}\right), 3.82-3.79$ (m, 6H, $\left.\mathrm{H}_{10}, 12\right), 3.54\left(\mathrm{~d}, J=12.3 \mathrm{~Hz}, 1 \mathrm{H}, \mathrm{H}_{5}\right), 3.24$ (bd, $\left.J=12.1 \mathrm{~Hz}, 1 \mathrm{H}, \mathrm{H}_{5}\right), 2.67$ (bs, 4H, $\left.\mathrm{H}_{11}\right), 2.16-2.12\left(\mathrm{~m}, 1 \mathrm{H}, \mathrm{H}_{3}\right), 2.08-1.98\left(\mathrm{~m}, 2 \mathrm{H}, \mathrm{H}_{2}, 3\right), 1.80-1.75\left(\mathrm{~m}, 1 \mathrm{H}, \mathrm{H}_{2}\right) .{ }^{13} \mathrm{C} \mathrm{NMR}(125$ $\left.\mathrm{MHz}, \mathrm{D}_{2} \mathrm{O}\right) \delta 170.2\left(\mathrm{C}_{6}\right), 142.0\left(\mathrm{C}_{9}\right), 125.8\left(\mathrm{C}_{8}\right), 66.0\left(2 \mathrm{C}, \mathrm{C}_{12}\right), 60.1\left(\mathrm{C}_{4}\right), 57.9\left(\mathrm{C}_{1}\right), 51.9(2 \mathrm{C}$, $\left.\mathrm{C}_{11}\right), 51.6\left(\mathrm{C}_{10}\right), 50.7\left(\mathrm{C}_{7}\right), 43.6\left(\mathrm{C}_{5}\right), 19.7\left(\mathrm{C}_{2}\right), 18.8\left(\mathrm{C}_{3}\right)$. HRMS calculated for $\mathrm{C}_{14} \mathrm{H}_{21} \mathrm{~N}_{6} \mathrm{O}_{6} \mathrm{~S}$ [M-H]-: 401.12433; found: 401.12557. [ $\alpha]_{\mathrm{D}}:-37.2^{\circ}(1.8 \mathrm{mg} / \mathrm{ml}, \mathrm{MeOH}) . \mathrm{HPLC}$ purity =95.1\%; $\mathrm{rt}=6.0 \mathrm{~min}\left(\mathrm{CH}_{3} \mathrm{CN} / \mathrm{H}_{2} \mathrm{O}\right.$ 0:100 to $100: 0$ over $\left.15 \mathrm{~min}\right)$.

Compound (7g). Following the general procedure for the introduction of sodium sulphite, compound $7 \mathbf{g}$ was obtained as a white solid (88 mg, 30\%) starting from compound $\mathbf{6 g}$ (283 mg, $0.64 \mathrm{mmol}) .{ }^{1} \mathrm{H}$ NMR (500 MHz, $\left.\mathrm{D}_{2} \mathrm{O}\right) \delta 8.01\left(\mathrm{~s}, 1 \mathrm{H}, \mathrm{H}_{8}\right), 4.92\left(\mathrm{dd}, J=14.8,10.3 \mathrm{~Hz}, 1 \mathrm{H}, \mathrm{H}_{7}\right)$, $4.69\left(\mathrm{dd}, J=14.8,5.7 \mathrm{~Hz}, 1 \mathrm{H}, \mathrm{H}_{7}\right), 4.39$ (s, 2H, $\left.\mathrm{H}_{10}\right), 4.31-4.29\left(\mathrm{~m}, 1 \mathrm{H}, \mathrm{H}_{4}\right), 3.97-3.92(\mathrm{~m}, 1 \mathrm{H}$, $\left.\mathrm{H}_{1}\right), 3.53\left(\mathrm{~d}, J=12.3 \mathrm{~Hz}, 1 \mathrm{H}, \mathrm{H}_{5}\right), 3.23\left(\mathrm{bd}, J=12.2 \mathrm{~Hz}, 1 \mathrm{H}, \mathrm{H}_{5}\right), 2.16-2.11\left(\mathrm{~m}, 1 \mathrm{H}, \mathrm{H}_{3}\right), 2.07$ $-1.97\left(\mathrm{~m}, 2 \mathrm{H}, \mathrm{H}_{2,3}\right), 1.78-1.74\left(\mathrm{~m}, 1 \mathrm{H}, \mathrm{H}_{2}\right), 1.47\left(\mathrm{~s}, 9 \mathrm{H}, \mathrm{H}_{13}\right) .{ }^{13} \mathrm{C} \mathrm{NMR}\left(125 \mathrm{MHz}, \mathrm{D}_{2} \mathrm{O}\right) \delta$ $170.1\left(\mathrm{C}_{6}\right), 158.0\left(\mathrm{C}_{11}\right), 146.0\left(\mathrm{C}_{9}\right), 123.8\left(\mathrm{C}_{8}\right), 81.4\left(\mathrm{C}_{12}\right), 60.1\left(\mathrm{C}_{4}\right), 57.9\left(\mathrm{C}_{1}\right), 50.7\left(\mathrm{C}_{7}\right), 43.6$ $\left(\mathrm{C}_{5}\right), 35.4\left(\mathrm{C}_{10}\right), 27.6\left(3 \mathrm{C}, \mathrm{C}_{13}\right), 19.7\left(\mathrm{C}_{2}\right), 18.8\left(\mathrm{C}_{3}\right)$. HRMS calculated for $\mathrm{C}_{15} \mathrm{H}_{23} \mathrm{~N}_{6} \mathrm{O}_{7} \mathrm{~S}$ [M$\mathrm{H}]^{-}:$431.13489; found: 431.13669. $[\alpha]_{\mathrm{D}}:-35.6^{\circ}\left(13.6 \mathrm{mg} / \mathrm{ml}, \mathrm{H}_{2} \mathrm{O}\right)$. HPLC purity $=96.9 \%$; $\mathrm{rt}=$ $10.2 \mathrm{~min}\left(\mathrm{CH}_{3} \mathrm{CN} / \mathrm{H}_{2} \mathrm{O}\right.$ 0:100 to $100: 0$ over $\left.15 \mathrm{~min}\right)$.

Compound (7h). Following the general procedure for the introduction of sodium sulphite, compound $7 \mathbf{h}$ was obtained as a white powder (184 mg, 53\%) starting from compound $\mathbf{6 h}$ (336 mg, $0.68 \mathrm{mmol}) .{ }^{1} \mathrm{H} \mathrm{NMR}\left(500 \mathrm{MHz}, \mathrm{D}_{2} \mathrm{O}\right) \delta 7.94\left(\mathrm{~s}, 1 \mathrm{H}, \mathrm{H}_{8}\right), 4.90(\mathrm{dd}, J=14.7,10.2 \mathrm{~Hz}, 1 \mathrm{H}$, $\left.\mathrm{H}_{7}\right), 4.67\left(\mathrm{dd}, J=14.7,5.8 \mathrm{~Hz}, 1 \mathrm{H}, \mathrm{H}_{7}\right), 4.31-4.29\left(\mathrm{~m}, 1 \mathrm{H}, \mathrm{H}_{4}\right), 4.13\left(\mathrm{bd}, J=12.7 \mathrm{~Hz}, 2 \mathrm{H}, \mathrm{H}_{12}\right)$, 3.97-3.92 (m, 1H, $\left.\mathrm{H}_{1}\right), 3.51\left(\mathrm{~d}, J=12.3 \mathrm{~Hz}, 1 \mathrm{H}, \mathrm{H}_{5}\right), 3.22\left(\mathrm{bd}, J=12.3 \mathrm{~Hz}, 1 \mathrm{H}, \mathrm{H}_{5}\right), 3.08-3.01$ 
(m, 3H, $\left.\mathrm{H}_{10}, 12\right), 2.17-2.11\left(\mathrm{~m}, 1 \mathrm{H}, \mathrm{H}_{3}\right), 2.07-1.98\left(\mathrm{~m}, 4 \mathrm{H}, \mathrm{H}_{2,3,11}\right), 1.77-1.71\left(\mathrm{~m}, 1 \mathrm{H}, \mathrm{H}_{2}\right), 1.66-$ $1.59\left(\mathrm{~m}, 2 \mathrm{H}, \mathrm{H}_{11}\right), 1.51\left(\mathrm{~s}, 9 \mathrm{H}, \mathrm{H}_{15}\right) .{ }^{13} \mathrm{C} \mathrm{NMR}\left(125 \mathrm{MHz}, \mathrm{D}_{2} \mathrm{O}\right) \delta 170.1\left(\mathrm{C}_{6}\right), 156.6\left(\mathrm{C}_{13}\right), 152.0$ $\left(\mathrm{C}_{9}\right), 122.4\left(\mathrm{C}_{8}\right), 81.6\left(\mathrm{C}_{14}\right), 60.1\left(\mathrm{C}_{4}\right), 57.9\left(\mathrm{C}_{1}\right), 50.6\left(\mathrm{C}_{7}\right), 43.6\left(3 \mathrm{C}, \mathrm{C}_{5}\right.$ and $\left.\mathrm{C}_{12}\right), 32.5\left(\mathrm{C}_{10}\right)$, $31.0\left(2 \mathrm{C}, \mathrm{C}_{11}\right), 27.7\left(3 \mathrm{C}, \mathrm{C}_{15}\right), 19.7\left(\mathrm{C}_{2}\right), 18.8\left(\mathrm{C}_{3}\right)$. HRMS calculated for $\mathrm{C}_{19} \mathrm{H}_{30} \mathrm{~N}_{6} \mathrm{O}_{7} \mathrm{~S}[\mathrm{M}+\mathrm{H}]^{+}$: 487.19749; found: 487.19849. [ $\alpha]_{\mathrm{D}}:-21.1^{\circ}\left(11.8 \mathrm{mg} / \mathrm{ml}, \mathrm{H}_{2} \mathrm{O}\right) . \mathrm{HPLC}$ purity $=95.1 \%$; $\mathrm{rt}=11.8$ $\min \left(\mathrm{CH}_{3} \mathrm{CN} / \mathrm{H}_{2} \mathrm{O}\right.$ 0:100 to 100:0 over $\left.15 \mathrm{~min}\right)$.

Compound (7i). Following the general procedure for the introduction of sodium sulphite, compound $7 \mathbf{i}$ was obtained as a white powder (37 mg, 23\%) starting from compound $6 \mathbf{i}$ (159 mg, $0.28 \mathrm{mmol}) .{ }^{1} \mathrm{H}$ NMR (500 MHz, $\left.\mathrm{D}_{2} \mathrm{O}\right) \delta 8.26\left(\mathrm{~s}, 1 \mathrm{H}, \mathrm{H}_{8}\right), 7.71\left(\mathrm{~d}, J=8.4 \mathrm{~Hz}, 2 \mathrm{H}, \mathrm{H}_{11}\right)$, $7.52\left(\mathrm{~d}, J=8.2 \mathrm{~Hz}, 2 \mathrm{H}, \mathrm{H}_{12}\right), 4.85\left(\mathrm{dd}, J=14.8,10.2 \mathrm{~Hz}, 1 \mathrm{H}, \mathrm{H}_{7}\right), 4.61(\mathrm{dd}, J=14.8,5.8 \mathrm{~Hz}$, $\left.1 \mathrm{H}, \mathrm{H}_{7}\right), 4.29-4.27\left(\mathrm{~m}, 1 \mathrm{H}, \mathrm{H}_{4}\right), 3.94-3.90\left(\mathrm{~m}, 1 \mathrm{H}, \mathrm{H}_{1}\right), 3.49\left(\mathrm{~d}, J=12.2 \mathrm{~Hz}, 1 \mathrm{H}, \mathrm{H}_{5}\right), 3.46(\mathrm{t}, J$ $\left.=6.1 \mathrm{~Hz}, 2 \mathrm{H}, \mathrm{H}_{16}\right), 3.21\left(\mathrm{~d}, J=12.1 \mathrm{~Hz}, 1 \mathrm{H}, \mathrm{H}_{5}\right), 2.59\left(\mathrm{t}, J=5.9 \mathrm{~Hz}, 2 \mathrm{H}, \mathrm{H}_{15}\right), 2.15-2.09$ (m, $\left.1 \mathrm{H}, \mathrm{H}_{3}\right), 2.03-1.94\left(\mathrm{~m}, 2 \mathrm{H}, \mathrm{H}_{2,3}\right), 1.74-1.67\left(\mathrm{~m}, 1 \mathrm{H}, \mathrm{H}_{2}\right), 1.39\left(\mathrm{~s}, 9 \mathrm{H}, \mathrm{H}_{19}\right) .{ }^{13} \mathrm{C} \mathrm{NMR}(125 \mathrm{MHz}$, $\left.\mathrm{D}_{2} \mathrm{O}\right) \delta 172.9\left(\mathrm{C}_{14}\right), 170.1\left(\mathrm{C}_{6}\right), 158.0\left(\mathrm{C}_{17}\right), 147.2\left(\mathrm{C}_{9}\right), 137.3\left(\mathrm{C}_{10}\right), 126.3\left(2 \mathrm{C}, \mathrm{C}_{11}\right), 126.2(2 \mathrm{C}$, $\left.\mathrm{C}_{13}\right), 122.1\left(\mathrm{C}_{8}\right), 121.8\left(2 \mathrm{C}, \mathrm{C}_{12}\right), 81.0\left(\mathrm{C}_{18}\right), 60.1\left(\mathrm{C}_{4}\right), 57.8\left(\mathrm{C}_{1}\right), 50.8\left(\mathrm{C}_{7}\right), 43.6\left(\mathrm{C}_{5}\right), 37.2$ $\left(\mathrm{C}_{15}\right), 36.8\left(\mathrm{C}_{16}\right), 27.6\left(3 \mathrm{C}, \mathrm{C}_{19}\right), 19.7\left(\mathrm{C}_{2}\right), 18.8\left(\mathrm{C}_{3}\right)$. HRMS calculated for $\mathrm{C}_{23} \mathrm{H}_{29} \mathrm{~N}_{7} \mathrm{O}_{8} \mathrm{~S}[\mathrm{M}-$ H] : 564.18766; found: 564.18766. $[\alpha]_{\mathrm{D}}:-12.2^{\circ}(3.0 \mathrm{mg} / \mathrm{ml}, \mathrm{MeOH}) . \mathrm{HPLC}$ purity $=99.1 \%$; $\mathrm{rt}$ $=11.4 \min \left(\mathrm{CH}_{3} \mathrm{CN} / \mathrm{H}_{2} \mathrm{O}\right.$ 0:100 to 100:0 over $\left.15 \mathrm{~min}\right)$.

Compound (7j). Following the general procedure for the introduction of sodium sulphite, compound $7 \mathbf{j}$ was obtained as a colorless foam (34 mg, 17\%) starting from compound $\mathbf{6 j}$ (194 mg, $0.50 \mathrm{mmol}) .{ }^{1} \mathrm{H}$ NMR ${ }^{1} \mathrm{H}$ NMR $\left(500 \mathrm{MHz}, \mathrm{D}_{2} \mathrm{O}\right) \delta 7.87\left(\mathrm{~s}, 1 \mathrm{H}, \mathrm{H}_{8}\right), 4.89(\mathrm{dd}, J=14.8$, $\left.10.1 \mathrm{~Hz}, 2 \mathrm{H}, \mathrm{H}_{7}\right), 4.66\left(\mathrm{dd}, J=14.8,6.0 \mathrm{~Hz}, 2 \mathrm{H}, \mathrm{H}_{7}\right), 4.29-4.28\left(\mathrm{~m}, 1 \mathrm{H}, \mathrm{H}_{4}\right), 3.97-3.91(\mathrm{~m}, 1 \mathrm{H}$, $\left.\mathrm{H}_{1}\right), 3.51\left(\mathrm{~d}, J=12.4 \mathrm{~Hz}, 1 \mathrm{H}, \mathrm{H}_{5}\right), 3.21\left(\mathrm{bd}, J=12.3 \mathrm{~Hz}, 1 \mathrm{H}, \mathrm{H}_{5}\right), 2.99\left(\mathrm{t}, J=7.6 \mathrm{~Hz}, 2 \mathrm{H}, \mathrm{H}_{10}\right)$, $2.57\left(\mathrm{t}, J=7.6 \mathrm{~Hz}, 2 \mathrm{H}, \mathrm{H}_{11}\right), 2.15-2.09\left(\mathrm{~m}, 1 \mathrm{H}, \mathrm{H}_{3}\right), 2.04-1.96\left(\mathrm{~m}, 2 \mathrm{H}, \mathrm{H}_{2,3}\right), 1.76-1.69(\mathrm{~m}, 1 \mathrm{H}$, $\left.\mathrm{H}_{2}\right) .{ }^{13} \mathrm{C}$ NMR $\left(125 \mathrm{MHz}, \mathrm{D}_{2} \mathrm{O}\right) \delta 181.7\left(\mathrm{C}_{12}\right), 170.1\left(\mathrm{C}_{6}\right), 148.0\left(\mathrm{C}_{9}\right), 123.3\left(\mathrm{C}_{8}\right), 60.0\left(\mathrm{C}_{4}\right)$, 
$57.8\left(\mathrm{C}_{1}\right), 50.5\left(\mathrm{C}_{7}\right), 43.7\left(\mathrm{C}_{5}\right), 36.7\left(\mathrm{C}_{11}\right), 21.8\left(\mathrm{C}_{10}\right), 19.6\left(\mathrm{C}_{2}\right), 18.8\left(\mathrm{C}_{3}\right)$. HRMS calculated for $\mathrm{C}_{12} \mathrm{H}_{16} \mathrm{~N}_{5} \mathrm{O}_{7} \mathrm{~S}$ [M-H]-: 374.07704; found: 374.07651 . [ $\left.\alpha\right]_{\mathrm{D}}:-17.2^{\circ}\left(16.4 \mathrm{mg} / \mathrm{ml}, \mathrm{H}_{2} \mathrm{O}\right)$. HPLC purity $=96,0 \% ; \mathrm{rt}=13.5 \min \left(\mathrm{CH}_{3} \mathrm{CN}+0.1 \% \mathrm{TFA} / \mathrm{H}_{2} \mathrm{O}+0.1 \%\right.$ TFA $0: 100$ to 100:0 over 30 $\min )$.

Compound (8g). Following the general procedure for the deprotection of Boc, compound $\mathbf{8 g}$ was obtained as a white powder (7.4 mg, 36\%) starting from compound $7 \mathbf{g}(21 \mathrm{mg}, 0.05 \mathrm{mmol})$. ${ }^{1} \mathrm{H}$ NMR $\left(500 \mathrm{MHz}, \mathrm{D}_{2} \mathrm{O}\right) \delta 8.26\left(\mathrm{~s}, 1 \mathrm{H}, \mathrm{H}_{8}\right), 4.99\left(\mathrm{dd}, J=14.8,10.9 \mathrm{~Hz}, 1 \mathrm{H}, \mathrm{H}_{7}\right), 4.72(\mathrm{dd}, J$ $\left.=14.8,5.2 \mathrm{~Hz}, 1 \mathrm{H}, \mathrm{H}_{7}\right), 4.40\left(\mathrm{~s}, 2 \mathrm{H}, \mathrm{H}_{10}\right), 4.32-4.30\left(\mathrm{~m}, 1 \mathrm{H}, \mathrm{H}_{4}\right), 3.99-3.94\left(\mathrm{~m}, 1 \mathrm{H}, \mathrm{H}_{1}\right), 3.57$ (d, $\left.J=12.3 \mathrm{~Hz}, 1 \mathrm{H}, \mathrm{H}_{5}\right), 3.24\left(\mathrm{bd}, J=12.3 \mathrm{~Hz}, 1 \mathrm{H}, \mathrm{H}_{5}\right), 2.17-2.12\left(\mathrm{~m}, 1 \mathrm{H}, \mathrm{H}_{3}\right), 2.10-1.99$ (m, $\left.2 \mathrm{H}, \mathrm{H}_{2,3}\right), 1.82-1.78\left(\mathrm{~m}, 1 \mathrm{H}, \mathrm{H}_{2}\right) .{ }^{13} \mathrm{C} \mathrm{NMR}\left(125 \mathrm{MHz}, \mathrm{D}_{2} \mathrm{O}\right) \delta 170.1\left(\mathrm{C}_{6}\right), 140.0\left(\mathrm{C}_{9}\right), 125.5$ $\left(\mathrm{C}_{8}\right), 60.1\left(\mathrm{C}_{4}\right), 58.0\left(\mathrm{C}_{1}\right), 50.8\left(\mathrm{C}_{7}\right), 43.5\left(\mathrm{C}_{5}\right), 34.1\left(\mathrm{C}_{10}\right), 19.8\left(\mathrm{C}_{2}\right), 18.8\left(\mathrm{C}_{3}\right)$. HRMS calculated for $\mathrm{C}_{10} \mathrm{H}_{15} \mathrm{~N}_{6} \mathrm{O}_{5} \mathrm{~S}$ [M-H] $:$ : 331.08246; found: $331.08277 .[\alpha]_{\mathrm{D}}:-40.2^{\circ}(2.5 \mathrm{mg} / \mathrm{ml}$, $\left.\mathrm{H}_{2} \mathrm{O}\right) . \mathrm{HPLC}$ purity $=97.7 \%$; $\mathrm{rt}=4.0 \mathrm{~min}\left(\mathrm{CH}_{3} \mathrm{CN} / \mathrm{H}_{2} \mathrm{O}\right.$ 0:100 to 100:0 over $\left.15 \mathrm{~min}\right)$.

Compound (8h). Following the general procedure for the deprotection of Boc, compound $\mathbf{8 h}$ was obtained as a white powder (20 mg, 34\%) starting from compound $7 \mathbf{h}$ (59 $\mathrm{mg}, 0.12 \mathrm{mmol})$. ${ }^{1} \mathrm{H}$ NMR $\left(500 \mathrm{MHz}, \mathrm{D}_{2} \mathrm{O}\right) \delta 8.00\left(\mathrm{~s}, 1 \mathrm{H}, \mathrm{H}_{8}\right), 4.91\left(\mathrm{dd}, J=14.8,10.6 \mathrm{~Hz}, 1 \mathrm{H}, \mathrm{H}_{7}\right), 4.66(\mathrm{dd}, J$ $\left.=14.8,5.5 \mathrm{~Hz}, 1 \mathrm{H}, \mathrm{H}_{7}\right), 4.29-4.27\left(\mathrm{~m}, 1 \mathrm{H}, \mathrm{H}_{4}\right), 3.96-3.91\left(\mathrm{~m}, 1 \mathrm{H}, \mathrm{H}_{1}\right), 3.57-3.51\left(\mathrm{~m}, 3 \mathrm{H}, \mathrm{H}_{5}\right.$, 12), 3.25-3.18 (m, 4H, H5, 10,12), 2.33-2.29 (m, 3H, 2H, $\left.\mathrm{H}_{11}\right), 2.16-2.09$ (m, 1H, $\left.\mathrm{H}_{3}\right), 2.06-1.93$ (m, 4H, H2,3,11), 1.77-1.71 (m, 1H, $\left.\mathrm{H}_{2}\right) .{ }^{13} \mathrm{C} \mathrm{NMR}\left(125 \mathrm{MHz}, \mathrm{D}_{2} \mathrm{O}\right) \delta 170.1\left(\mathrm{C}_{6}\right), 150.3\left(\mathrm{C}_{9}\right)$, $122.6\left(\mathrm{C}_{8}\right), 60.1\left(\mathrm{C}_{4}\right), 57.9\left(\mathrm{C}_{1}\right), 50.7\left(\mathrm{C}_{7}\right), 43.6\left(3 \mathrm{C}, \mathrm{C}_{5}\right.$ and $\left.\mathrm{C}_{12}\right), 30.28\left(\mathrm{C}_{10}\right), 27.8\left(2 \mathrm{C}, \mathrm{C}_{11}\right)$, $19.7\left(\mathrm{C}_{2}\right), 18.82\left(\mathrm{C}_{3}\right)$. HRMS calculated for $\mathrm{C}_{14} \mathrm{H}_{21} \mathrm{~N}_{6} \mathrm{O}_{5} \mathrm{~S}$ [M-H]: 385.12941; found: 385.13052. $[\alpha]_{\mathrm{D}}:-37.2^{\circ}\left(13.7 \mathrm{mg} / \mathrm{ml}, \mathrm{H}_{2} \mathrm{O}\right)$. HPLC purity $=97.6 \% ; \mathrm{rt}=9.6 \mathrm{~min}\left(\mathrm{CH}_{3} \mathrm{CN} / \mathrm{H}_{2} \mathrm{O}\right.$ 0:100 to $100: 0$ over $15 \mathrm{~min})$.

Compound (8i). Following the general procedure for the deprotection of Boc, compound $\mathbf{8 i}$ was obtained as a white solid (2.4 mg, 17\%) starting from compound $7 \mathbf{i}$ (14 mg, $0.02 \mathrm{mmol})$. 
${ }^{1} \mathrm{H}$ NMR $\left(500 \mathrm{MHz},\left(\mathrm{CD}_{3}\right)_{2} \mathrm{SO}\right) \delta 10.21(\mathrm{~s}, 1 \mathrm{H}, \mathrm{NH}), 8.49\left(\mathrm{~s}, 1 \mathrm{H}, \mathrm{H}_{8}\right), 7.80(\mathrm{~d}, J=8.7 \mathrm{~Hz}, 2 \mathrm{H}$, $\left.\mathrm{H}_{11}\right), 7.68\left(\mathrm{~d}, J=8.7 \mathrm{~Hz}, 2 \mathrm{H}, \mathrm{H}_{12}\right), 4.79\left(\mathrm{dd}, J=14.3,9.8 \mathrm{~Hz}, 1 \mathrm{H}, \mathrm{H}_{7}\right), 4.59(\mathrm{dd}, J=14.4,6.1$ $\left.\mathrm{Hz}, 1 \mathrm{H}, \mathrm{H}_{7}\right), 4.04-4.02\left(\mathrm{~m}, 1 \mathrm{H}, \mathrm{H}_{4}\right), 3.68-3.63\left(\mathrm{~m}, 1 \mathrm{H}, \mathrm{H}_{1}\right), 3.40\left(\mathrm{~d}, J=11.9 \mathrm{~Hz}, 1 \mathrm{H}, \mathrm{H}_{5}\right), 3.11$ $\left(\mathrm{t}, J=6.5 \mathrm{~Hz}, 2 \mathrm{H}, \mathrm{H}_{16}\right), 2.91\left(\mathrm{bd}, J=11.9 \mathrm{~Hz}, 1 \mathrm{H}, \mathrm{H}_{5}\right), 2.71\left(\mathrm{t}, J=6.5 \mathrm{~Hz}, 2 \mathrm{H}, \mathrm{H}_{15}\right), 1.87-1.75$ (m, 3H, $\left.\mathrm{H}_{2,3}\right), 1.56-1.50\left(\mathrm{~m}, 1 \mathrm{H}, \mathrm{H}_{2}\right) .{ }^{13} \mathrm{C} \mathrm{NMR}\left(125 \mathrm{MHz},\left(\mathrm{CD}_{3}\right)_{2} \mathrm{SO}\right) \delta 168.4\left(\mathrm{C}_{14}\right), 167.3$ $\left(\mathrm{C}_{6}\right), 146.1\left(\mathrm{C}_{9}\right), 138.3\left(\mathrm{C}_{10}\right), 126.0\left(\mathrm{C}_{13}\right), 125.7\left(2 \mathrm{C}, \mathrm{C}_{11}\right), 121.2\left(\mathrm{C}_{8}\right), 119.4\left(2 \mathrm{C}, \mathrm{C}_{12}\right), 58.1$ $\left(\mathrm{C}_{4}\right), 56.9\left(\mathrm{C}_{1}\right), 50.5\left(\mathrm{C}_{7}\right), 43.3\left(\mathrm{C}_{5}\right), 34.8\left(\mathrm{C}_{16}\right), 33.0\left(\mathrm{C}_{15}\right), 19.8\left(\mathrm{C}_{2}\right), 19.3\left(\mathrm{C}_{3}\right)$. HRMS calculated for $\mathrm{C}_{18} \mathrm{H}_{22} \mathrm{~N}_{7} \mathrm{O}_{6} \mathrm{~S}[\mathrm{M}-\mathrm{H}]^{-}:$464.13523; found: 464.13516. HPLC purity $=98.5 \%$; $\mathrm{rt}=$ $10.5 \min \left(\mathrm{CH}_{3} \mathrm{CN} / \mathrm{H}_{2} \mathrm{O}\right.$ 0:100 to $100: 0$ over $\left.15 \mathrm{~min}\right)$.

Compound (3). Ethyl chloroformate $(115 \mu 1,1.20 \mathrm{mmol})$ was added dropwise at $-10^{\circ} \mathrm{C}$ to a solution of compound $2(300 \mathrm{mg}, 1.09 \mathrm{mmol})$ and $\mathrm{N}$-methylmorpholine (358 $\mu 1,3.26 \mathrm{mmol})$ in THF $(5 \mathrm{ml})$. The solution was stirred at $-10^{\circ} \mathrm{C}$ for $1 \mathrm{~h}$ then at $5^{\circ} \mathrm{C}$ overnight. The reaction mixture was cooled again to $-10^{\circ} \mathrm{C}$ and $\mathrm{NaBH}_{4}(124 \mathrm{mg}, 3.26 \mathrm{mmol})$ was added gradually. The solution was then stirred for $1 \mathrm{~h} 30 \mathrm{~min}$ at $-10^{\circ} \mathrm{C}$. Water $(5 \mathrm{ml})$ and ethyl acetate $(5 \mathrm{ml})$ were slowly added and the heterogeneous mixture was stirred for $30 \mathrm{~min}$ at room temperature. The phases were separated, and the aqueous layer was extracted with ethyl acetate. The combined organic layers were washed with brine, dried over $\mathrm{MgSO}_{4}$, and concentrated under reduced pressure. Purification by flash chromatography using DCM/MeOH (96/4) as the eluent gave compound 3 as a colorless oil (88 mg, 31\%). ${ }^{1} \mathrm{H}$ NMR $\left(500 \mathrm{MHz}, \mathrm{CDCl}_{3}\right) \delta 7.40-7.29(\mathrm{~m}$, $\left.5 \mathrm{H}, \mathrm{H}_{10,11,12}\right), 5.00\left(\mathrm{~d}, J=11.4 \mathrm{~Hz}, 1 \mathrm{H}, \mathrm{H}_{8}\right), 4.85\left(\mathrm{~d}, J=11.4 \mathrm{~Hz}, 1 \mathrm{H}, \mathrm{H}_{8}\right), 3.69(\mathrm{dd}, J=11.3$, $\left.9.4 \mathrm{~Hz}, 1 \mathrm{H}, \mathrm{H}_{7}\right), 3.57\left(\mathrm{dd}, J=11.4,5.5 \mathrm{~Hz}, 1 \mathrm{H}, \mathrm{H}_{7}\right), 3.52-3.47\left(\mathrm{~m}, 1 \mathrm{H}, \mathrm{H}_{1}\right), 3.33-3.31(\mathrm{~m}, 1 \mathrm{H}$, $\left.\mathrm{H}_{4}\right), 2.99\left(\mathrm{~d}, J=11.7 \mathrm{~Hz}, 1 \mathrm{H}, \mathrm{H}_{5}\right), 2.87\left(\mathrm{bd}, J=11.6 \mathrm{~Hz}, 1 \mathrm{H}, \mathrm{H}_{5}\right), 1.99-1.93\left(\mathrm{~m}, 1 \mathrm{H}, \mathrm{H}_{3}\right), 1.93-$ $1.86\left(\mathrm{~m}, 1 \mathrm{H}, \mathrm{H}_{2}\right), 1.57-1.51\left(\mathrm{~m}, 1 \mathrm{H}, \mathrm{H}_{3}\right), 1.41-1.35\left(\mathrm{~m}, 1 \mathrm{H}, \mathrm{H}_{2}\right) .{ }^{13} \mathrm{C} \mathrm{NMR}\left(125 \mathrm{MHz}, \mathrm{CDCl}_{3}\right)$ $\delta 170.1\left(\mathrm{C}_{6}\right), 136.1\left(\mathrm{C}_{9}\right), 129.4\left(2 \mathrm{C}, \mathrm{C}_{10}\right), 128.8\left(\mathrm{C}_{12}\right), 128.7\left(2 \mathrm{C}, \mathrm{C}_{11}\right), 78.4\left(\mathrm{C}_{8}\right), 62.6\left(\mathrm{C}_{7}\right)$, 
$58.8\left(\mathrm{C}_{1}\right), 58.6\left(\mathrm{C}_{4}\right), 43.5\left(\mathrm{C}_{5}\right), 20.1\left(\mathrm{C}_{3}\right), 19.4\left(\mathrm{C}_{2}\right)$. HRMS calculated for $\mathrm{C}_{14} \mathrm{H}_{19} \mathrm{~N}_{2} \mathrm{O}_{3}[\mathrm{M}+\mathrm{H}]^{+}$: 263.13957; found: 263.13852. [ $\alpha]_{\mathrm{D}}:-54.5^{\circ}(4.0 \mathrm{mg} / \mathrm{ml}, \mathrm{MeOH})$.

Compound (9a) and (9b). N,N-Diisopropylethylamine (598 $\mu 1,3.43$ mmol), DMAP (14 mg, $0.11 \mathrm{mmol})$ and $\mathrm{MsCl}(133 \mu \mathrm{l}, 1.72 \mathrm{mmol})$ were added at $0^{\circ} \mathrm{C}$ to a solution of $2(300 \mathrm{mg}, 1.14$ mmol) in DCM (25 ml). The reaction mixture was stirred at $0^{\circ} \mathrm{C}$ for $1 \mathrm{~h}$. DCM was then added and the organic layer was washed with brine, dried over $\mathrm{MgSO}_{4}$ and concentrated under vacuum to afford compound $\mathbf{3}$ which was used in the next step without further purification. A solution of crude product 3 (1.14 mmol) in acetonitrile $(18 \mathrm{ml})$ was added dropwise to a solution of $1 \mathrm{H}-$ 1,2,3-triazole $(133 \mu 1,2.29 \mathrm{mmol})$ and $\operatorname{tBuOK}(257 \mathrm{mg}, 2.29 \mathrm{mmol})$ in acetonitrile $(24 \mathrm{ml})$. The reaction mixture was stirred at $90^{\circ} \mathrm{C}$ for $15 \mathrm{~h}$. DCM was then added and the organic layer was washed with $\mathrm{H}_{2} \mathrm{O}$ and brine, dried over $\mathrm{MgSO}_{4}$ and concentrated under vacuum. Purification by flash chromatography using cyclohexane/ethyl acetate $(9 / 1)$ as the eluent gave compounds 9a (164 mg, 44\% over 2 steps) and 9b (136 mg, 37\% over 2 steps) as orange solids. 9a: ${ }^{1} \mathrm{H}$ NMR (500 MHz, $\left.\mathrm{CDCl}_{3}\right) \delta 7.55\left(\mathrm{~s}, 2 \mathrm{H}, \mathrm{H}_{8}\right), 7.38-7.27\left(\mathrm{~m}, 5 \mathrm{H}, \mathrm{H}_{11}, 12,13\right), 4.98(\mathrm{~d}, J=11.5 \mathrm{~Hz}$, $\left.1 \mathrm{H}, \mathrm{H}_{9}\right), 4.84\left(\mathrm{~d}, J=11.5 \mathrm{~Hz}, 1 \mathrm{H}, \mathrm{H}_{9}\right), 4.66\left(\mathrm{dd}, J=13.8,7.7 \mathrm{~Hz}, 1 \mathrm{H}, \mathrm{H}_{7}\right), 4.52(\mathrm{dd}, J=13.8$, 7.7 Hz, 1H, $\left.\mathrm{H}_{7}\right), 4.03-3.98\left(\mathrm{~m}, 1 \mathrm{H}, \mathrm{H}_{1}\right), 3.32\left(\mathrm{q}, J=3.0 \mathrm{~Hz}, 1 \mathrm{H}, \mathrm{H}_{4}\right), 2.99(\mathrm{~d}, J=11.9 \mathrm{~Hz}, 1 \mathrm{H}$, $\left.\mathrm{H}_{5}\right), 2.90\left(\mathrm{dt}, J=11.9,3.0 \mathrm{~Hz}, 1 \mathrm{H}, \mathrm{H}_{5}\right), 2.01-1.95\left(\mathrm{~m}, 1 \mathrm{H}, \mathrm{H}_{3}\right), 1.93-1.86\left(\mathrm{~m}, 1 \mathrm{H}, \mathrm{H}_{2}\right), 1.63-$ $1.57\left(\mathrm{~m}, 1 \mathrm{H}, \mathrm{H}_{3}\right), 1.46-1.40\left(\mathrm{~m}, 1 \mathrm{H}, \mathrm{H}_{2}\right) .{ }^{13} \mathrm{C} \mathrm{NMR}\left(125 \mathrm{MHz}, \mathrm{CDCl}_{3}\right) \delta 169.2\left(\mathrm{C}_{6}\right), 135.8\left(\mathrm{C}_{10}\right)$, $134.5\left(2 \mathrm{C}, \mathrm{C}_{8}\right), 129.1\left(2 \mathrm{C}, \mathrm{C}_{12}\right), 128.6\left(\mathrm{C}_{13}\right), 128.4\left(2 \mathrm{C}, \mathrm{C}_{11}\right), 78.1\left(\mathrm{C}_{9}\right), 58.2\left(\mathrm{C}_{4}\right), 56.6\left(\mathrm{C}_{1}\right)$, $55.9\left(\mathrm{C}_{7}\right), 44.3\left(\mathrm{C}_{5}\right), 19.9\left(\mathrm{C}_{2}\right), 19.8\left(\mathrm{C}_{3}\right)$. HRMS calculated for $\mathrm{C}_{16} \mathrm{H}_{20} \mathrm{~N}_{5} \mathrm{O}_{2}[\mathrm{M}+\mathrm{H}]^{+}: 314.16170$ ; found: $314.16104 .[\alpha]_{\mathrm{D}}:-32.3^{\circ}(6.0 \mathrm{mg} / \mathrm{ml}, \mathrm{MeOH}) .9 \mathrm{~b}:{ }^{1} \mathrm{H} \mathrm{NMR}\left(500 \mathrm{MHz}, \mathrm{CDCl}_{3}\right) \delta 7.72$ $\left(\mathrm{d}, J=0.8 \mathrm{~Hz}, 1 \mathrm{H}, \mathrm{H}_{8}\right), 7.66\left(\mathrm{~d}, J=0.8 \mathrm{~Hz}, 1 \mathrm{H}, \mathrm{H}_{9}\right), 7.39-7.29\left(\mathrm{~m}, 5 \mathrm{H}, \mathrm{H}_{12,13,14}\right), 4.98(\mathrm{~d}, J=$ $\left.11.5 \mathrm{~Hz}, 1 \mathrm{H}, \mathrm{H}_{10}\right), 4.84\left(\mathrm{~d}, J=11.5 \mathrm{~Hz}, 1 \mathrm{H}, \mathrm{H}_{10}\right), 4.56\left(\mathrm{dd}, J=14.2,8.0 \mathrm{~Hz}, 1 \mathrm{H}, \mathrm{H}_{7}\right), 4.51$ (dd, $\left.J=14.2,6.9 \mathrm{~Hz}, 1 \mathrm{H}, \mathrm{H}_{7}\right), 3.81-3.76\left(\mathrm{~m}, 1 \mathrm{H}, \mathrm{H}_{1}\right), 3.36-3.34\left(\mathrm{~m}, 1 \mathrm{H}, \mathrm{H}_{4}\right), 2.90\left(\mathrm{bs}, 2 \mathrm{H}, \mathrm{H}_{5}\right), 2.05-$ $1.99\left(\mathrm{~m}, 1 \mathrm{H}, \mathrm{H}_{3}\right), 1.96-1.89\left(\mathrm{~m}, 1 \mathrm{H}, \mathrm{H}_{2}\right), 1.69-1.62\left(\mathrm{~m}, 1 \mathrm{H}, \mathrm{H}_{3}\right), 1.57-1.51\left(\mathrm{~m}, 1 \mathrm{H}, \mathrm{H}_{2}\right) .{ }^{13} \mathrm{C}$ 
NMR (125 MHz, $\left.\mathrm{CDCl}_{3}\right) \delta 169.3\left(\mathrm{C}_{6}\right), 135.7\left(\mathrm{C}_{11}\right), 134.1\left(\mathrm{C}_{9}\right), 129.2\left(2 \mathrm{C}, \mathrm{C}_{13}\right), 128.8\left(\mathrm{C}_{14}\right)$, $128.6\left(2 \mathrm{C}, \mathrm{C}_{12}\right), 124.0\left(\mathrm{C}_{8}\right), 78.2\left(\mathrm{C}_{10}\right), 58.3\left(\mathrm{C}_{4}\right), 56.7\left(\mathrm{C}_{1}\right), 51.7\left(\mathrm{C}_{7}\right), 43.7\left(\mathrm{C}_{5}\right), 20.3\left(\mathrm{C}_{2}\right), 19.7$ $\left(\mathrm{C}_{3}\right)$. HRMS calculated for $\mathrm{C}_{16} \mathrm{H}_{20} \mathrm{~N}_{5} \mathrm{O}_{2}[\mathrm{M}+\mathrm{H}]^{+}: 314.16170$; found: 314.16113. $[\alpha]_{D}:-32.9^{\circ}$ (3.4 mg/ml, $\mathrm{MeOH})$.

Compound (10a). Following the general procedure for the introduction of sodium sulphite, compound 10a was obtained as a yellow solid (44 mg, 27\%) starting from compound 9a (158 mg, $0.51 \mathrm{mmol}) .{ }^{1} \mathrm{H}$ NMR ${ }^{1} \mathrm{H}$ NMR (500 MHz, $\left.\mathrm{D}_{2} \mathrm{O}\right) \delta 7.89\left(\mathrm{~s}, 2 \mathrm{H}, \mathrm{H}_{8}\right), 5.04(\mathrm{dd}, J=14.7$, $\left.10.4 \mathrm{~Hz}, 1 \mathrm{H}, \mathrm{H}_{7}\right), 4.77\left(\mathrm{dd}, J=14.7,5.8 \mathrm{~Hz}, 1 \mathrm{H}, \mathrm{H}_{7}\right), 4.33-4.31\left(\mathrm{~m}, 1 \mathrm{H}, \mathrm{H}_{4}\right), 4.10-4.05(\mathrm{~m}, 1 \mathrm{H}$, $\left.\mathrm{H}_{1}\right), 3.58\left(\mathrm{~d}, J=12.3 \mathrm{~Hz}, 1 \mathrm{H}, \mathrm{H}_{5}\right), 3.22\left(\mathrm{bd}, J=12.3 \mathrm{~Hz}, 1 \mathrm{H}, \mathrm{H}_{5}\right), 2.19-2.12\left(\mathrm{~m}, 1 \mathrm{H}, \mathrm{H}_{3}\right), 2.08-$ $1.99\left(\mathrm{~m}, 2 \mathrm{H}, \mathrm{H}_{2,3}\right), 1.81-1.73\left(\mathrm{~m}, 1 \mathrm{H}, \mathrm{H}_{2}\right) .{ }^{13} \mathrm{C} \mathrm{NMR}\left(125 \mathrm{MHz}, \mathrm{D}_{2} \mathrm{O}\right) \delta 169.9\left(\mathrm{C}_{6}\right), 135.1(2 \mathrm{C}$, $\left.\mathrm{C}_{8}\right), 60.0\left(\mathrm{C}_{4}\right), 57.8\left(\mathrm{C}_{1}\right), 54.6\left(\mathrm{C}_{7}\right), 43.9\left(\mathrm{C}_{5}\right), 19.5\left(\mathrm{C}_{2}\right), 18.9\left(\mathrm{C}_{3}\right)$. HRMS calculated for $\mathrm{C}_{9} \mathrm{H}_{12} \mathrm{~N}_{5} \mathrm{O}_{5} \mathrm{~S}[\mathrm{M}-\mathrm{H}]^{-}:$302.05591; found: 302.05685. [ $\left.\alpha\right]_{D}:-37.4^{\circ}\left(18.0 \mathrm{mg} / \mathrm{ml}, \mathrm{H}_{2} \mathrm{O}\right)$. HPLC purity $=97.0 \% ; \mathrm{rt}=2.8 \min \left(\mathrm{CH}_{3} \mathrm{CN} / \mathrm{H}_{2} \mathrm{O} 0: 100\right.$ to $100: 0$ over $\left.30 \mathrm{~min}\right)$.

Compound (10b). Following the general procedure for the introduction of sodium sulphite, compound $\mathbf{1 0 b}$ was obtained as a white foam (14 mg, 8\%) starting from compound $\mathbf{9 b}$ (132 mg, $0.42 \mathrm{mmol}) .{ }^{1} \mathrm{H} \mathrm{NMR}{ }^{1} \mathrm{H}$ NMR $\left(500 \mathrm{MHz}, \mathrm{D}_{2} \mathrm{O}\right) \delta 8.13$ (s, 1H, $\left.\mathrm{H}_{8}\right), 7.88\left(\mathrm{~s}, 1 \mathrm{H}, \mathrm{H}_{9}\right), 5.00$ $\left(\mathrm{dd}, J=14.8,10.5 \mathrm{~Hz}, 1 \mathrm{H}, \mathrm{H}_{7}\right), 4.74\left(\mathrm{dd}, J=14.8,5.6 \mathrm{~Hz}, 1 \mathrm{H}, \mathrm{H}_{7}\right), 4.32-4.30\left(\mathrm{~m}, 1 \mathrm{H}, \mathrm{H}_{4}\right), 4.01$ $-3.96\left(\mathrm{~m}, 1 \mathrm{H}, \mathrm{H}_{1}\right), 3.57\left(\mathrm{~d}, J=12.3 \mathrm{~Hz}, 1 \mathrm{H}, \mathrm{H}_{5}\right), 3.24\left(\mathrm{bd}, J=12.3 \mathrm{~Hz}, 1 \mathrm{H}, \mathrm{H}_{5}\right), 2.19-2.12(\mathrm{~m}$, $\left.1 \mathrm{H}, \mathrm{H}_{3}\right), 2.09-1.99\left(\mathrm{~m}, 2 \mathrm{H}, \mathrm{H}_{2}, 3\right), 1.82-1.74\left(\mathrm{~m}, 1 \mathrm{H}, \mathrm{H}_{2}\right) .{ }^{13} \mathrm{C} \mathrm{NMR}\left(125 \mathrm{MHz}, \mathrm{D}_{2} \mathrm{O}\right) \delta 170.1$ $\left(\mathrm{C}_{6}\right), 134.2\left(\mathrm{C}_{9}\right), 125.9\left(\mathrm{C}_{8}\right), 60.0\left(\mathrm{C}_{4}\right), 58.0\left(\mathrm{C}_{1}\right), 50.4\left(\mathrm{C}_{7}\right), 43.6\left(\mathrm{C}_{5}\right), 19.7\left(\mathrm{C}_{2}\right), 18.8\left(\mathrm{C}_{3}\right)$. HRMS calculated for $\mathrm{C}_{9} \mathrm{H}_{12} \mathrm{~N}_{5} \mathrm{O}_{5} \mathrm{~S}[\mathrm{M}-\mathrm{H}]$ ]: 302.05591 ; found: 302.05670 . [ $\left.\alpha\right]_{\mathrm{D}}$ : $-44.6^{\circ}$ (9.6 $\left.\mathrm{mg} / \mathrm{ml}, \mathrm{H}_{2} \mathrm{O}\right) . \mathrm{HPLC}$ purity $=97.9 \% ; \mathrm{rt}=2.8 \mathrm{~min}\left(\mathrm{CH}_{3} \mathrm{CN} / \mathrm{H}_{2} \mathrm{O}\right.$ 0:100 to 100:0 over $\left.30 \mathrm{~min}\right)$.

Plasmid and strain construction. For antibiotic susceptibility testing, the $\beta$-lactamase genes were cloned into the pTRC-99k vector, which is a derivative of pTRC99a (Pharmacia) obtained by replacing the $\beta$-lactamase resistance gene by a kanamycin resistance gene $(\mathrm{Km}$, lacI, pTRC 
promoter, oriVcolEI; D. Mengin-Lecreulx, unpublished). Recombinant plasmids were introduced by electrotransformation into $E$. coli Top10. For $\beta$-lactamase production, fragments of the $\beta$-lactamase genes encoding soluble enzymes, i.e. devoid of the signal peptides, were cloned into the pET-TEV vector generating translational fusions with a vector-encoded Nterminal $6 \mathrm{x}$ His tag followed by a TEV cleavage site (MHHHHHHENLYFQGHM).

Production and purification of $\beta$-lactamases. E. coli BL21 (DE3) harboring recombinant plasmids were grown in brain heart infusion (BHI) broth supplemented with kanamycin (50 $\mu \mathrm{g} / \mathrm{ml})$ at $37^{\circ} \mathrm{C}$ under vigorous shaking until the optical density at $600 \mathrm{~nm}\left(\mathrm{OD}_{600}\right)$ reached 0.8 . Isopropyl $\beta$-D-1-thiogalactopyranoside IPTG $(0.5 \mathrm{mM})$ was added and incubation was continued at $16^{\circ} \mathrm{C}$ for $18 \mathrm{~h}$. Bacteria were harvested by centrifugation, re-suspended in $25 \mathrm{mM}$ Tris- $\mathrm{HCl}$ ( $\mathrm{pH}$ 7.5) containing $300 \mathrm{mM} \mathrm{NaCl}$ (buffer A), and lysed by sonication. The enzymes were purified from clarified lysates by affinity chromatography (NiNTA agarose, SigmaAldrich) and size exclusion chromatography in buffer A (Superdex 200 HL26/60, Amersham Pharmacia Biotech). Protein concentration was determined by the Biorad protein assay using bovine serum albumin as a standard.

Determination of kinetic parameters. Kinetic parameters $k_{\mathrm{cat}}, K_{\mathrm{m}}$, and $k_{\mathrm{cat}} / K_{\mathrm{m}}$ for hydrolysis of nitrocefin and CENTA were determined at $20^{\circ} \mathrm{C}$ in $2-(N$-morpholino)ethanesulfonic acid (MES; $100 \mathrm{mM}$; pH 6.4) by spectrophotometry, as previously described. ${ }^{39,40}$ Briefly, the initial velocity $\left(v_{\mathrm{i}}\right)$ was determined by spectrophotometry for various concentrations of $\beta$-lactams $[\mathrm{S}]$ and a fixed concentration of $\beta$-lactamase [E]. The values of $v_{\mathrm{i}}$ were plotted as a function of $[\mathrm{S}]$. The kinetic constants $K_{\mathrm{m}}$ and $k_{\mathrm{cat}}$ were determined by fitting the equation $v_{\mathrm{i}}=k_{\mathrm{cat}}[\mathrm{E}][\mathrm{S}] / K_{\mathrm{m}}+$ [S] to the resulting curve. The molecular extinction coefficient was $15,200 \mathrm{M}^{-1} \mathrm{~cm}^{-1}$ at $486 \mathrm{~nm}$ for nitrocefin and 7,380 $\mathrm{M}^{-1} \mathrm{~cm}^{-1}$ at $415 \mathrm{~nm}$ for CENTA, respectively. Kinetic parameters for the carbamoylation of $\beta$-lactamases by DBOs $\left(k_{2} / K_{\mathrm{i}}\right.$ and $\left.k_{-2}\right)$ were determined at $20^{\circ} \mathrm{C}$ in MES (100 mM; pH 6.4), as previously described. ${ }^{7}$ The reporter substrate was nitrocefin $(100 \mu \mathrm{M})$ 
for TEM-1, KPC-2, CTX-M-15, and AmpC $\mathrm{Clo}_{\text {clo }}$ or CENTA (100 $\left.\mu \mathrm{M}\right)$ for OXA-48. Kinetics constants were deduced from a minimum of 6 progress curves obtained in a minimum of two independent experiments.

MIC determination. MICs of $\beta$-lactams were determined by the microdilution method in Mueller-Hinton (cation-adjusted) broth according to Clinical and Laboratory Standards Institute (CLSI) recommendations. ${ }^{41}$ Diazabicyclooctanes were used at a fixed concentration of $15 \mu \mathrm{M}(4 \mu \mathrm{g} / \mathrm{ml}$ for avibactam). Clavulanate was tested at $4 \mu \mathrm{g} / \mathrm{ml}$. IPTG (500 $\mu \mathrm{M})$ was added to the microdilution plates to induce production of the $\beta$-lactamase. The precultures were grown in BHI broth containing IPTG $(500 \mu \mathrm{M})$ and kanamycin $(50 \mu \mathrm{g} / \mathrm{ml})$ for plasmid maintenance. Reported MICs are the medians from five biological repeats obtained in two independent experiments.

\section{ASSOCIATED CONTENT}

\section{Supporting Information}

The Supporting Information is available free of charge on the ACS Publications website.

Synthesis and characterization of alkyne 5f, 5g and 5i (PDF)

Synthesis and characterization of relebactam (PDF)

NMR analysis (PDF)

Table of Kinetic constant $k-2\left(\mathrm{~s}^{-1}\right)$ for decarbamoylation of $\beta$-lactamases with synthesized compounds (PDF)

Molecular formula strings (CSV)

\section{AUTHOR INFORMATION}

\section{Corresponding Author}

*E.mail: laura.iannazzo@parisdescartes.fr; Phone: (33) 1428620 20; 


\begin{abstract}
*E.mail: melanie.etheve-quelquejeu@parisdescartes.fr; Phone: (33) 1428640 26;
*E.mail: michel.arthur@crc.jussieu.fr; Phone (33) 144275477.
\end{abstract}

\title{
Author Contributions \\ ${ }^{1}$ These authors contributed equally.
}

\section{Notes}

The authors declare no competing financial interest.

\section{ACKNOWLEDGMENT}

This research was funded by grants from the Agence National de la Recherche (ANR), Project MycWall ( $\mathrm{N}^{\circ}$ ANR-17-CE18-0010-01). The authors are grateful to Atlanchim Pharma for the synthesis of compound 4 in large scale. We thank ANTABIO (https://antabio.com/) for the determination of the MICs of $\beta$-lactam- $\beta$-lactamase inhibitor combinations against clinical isolates of enterobacteria from the company collection.

\begin{abstract}
ABBREVIATIONS
CuAAC, copper-catalyzed alkyne-azide cycloaddition; DBO, diazabicyclooctane; DCM, dichloromethane; DMAP, $N$-dimethylaminopyridine; DMF, $N$-dimethylformamide; HPLC, high performance liquid chromatography; HRMS, high resolution mass spectroscopy; KPC, Klebsiella pneumoniae carbapenemases; MIC, minimal inhibitory concentration; NMR, nuclear magnetic resonance; TFA, trifluoroacetic acid; THF, tetrahydrofuran; TLC, thin layer chromatography.
\end{abstract}

\section{REFERENCES}

(1) Lobanovska, M.; Pilla, G., Penicillin's discovery and antibiotic resistance: lessons for the future? Yale J. Biol. Med. 2017, 90, 135-145. 
(2) Zapun, A.; Contreras-Martel, C.; Vernet, T., Penicillin-binding proteins and beta-lactam resistance. Fems Microbiol. Rev. 2008, 32, 361-385.

(3) Bush, K.; Bradford, P., Interplay between $\beta$-lactamases and new $\beta$-lactamase inhibitors. Nat. Rev. 2019, 17, 295-306.

(4) Drawz, S. M.; Bonomo, R. A., Three decades of beta-lactamase inhibitors. Clin. Microbiol. Rev. 2010, 23, 160-201.

(5) Wang, D. Y.; Abboud, M. I.; Markoulides, M. S.; Brem, J.; Schofield, C. J., The road to avibactam: the first clinically useful non-beta-lactam working somewhat like a beta-lactam. Future Med. Chem. 2016, 8, 1063-1084.

(6) Ehmann, D. E.; Jahic, H.; Ross, P. L.; Gu, R. F.; Hu, J.; Durand-Reville, T. F.; Lahiri, S.; Thresher, J.; Livchak, S.; Gao, N.; Palmer, T.; Walkup, G. K.; Fisher, S. L., Kinetics of avibactam inhibition against Class A, C, and D beta-lactamases. J. Biol. Chem. 2013, 288, 27960-27971.

(7) Ehmann, D. E.; Jahic, H.; Ross, P. L.; Gu, R. F.; Hu, J.; Kern, G.; Walkup, G. K.; Fisher, S. L., Avibactam is a covalent, reversible, non-beta-lactam beta-lactamase inhibitor. Proc. Natl. Acad. Sci. U. S. A. 2012, 109, 11663-11668.

(8) Choi, H.; Paton, R. S.; Park, H.; Schofield, C. J., Investigations on recyclisation and hydrolysis in avibactam mediated serine beta-lactamase inhibition. Org. Biomol. Chem. 2016, $14,4116-4128$.

(9) Das, C.; Nair, N., Molecular insights into avibactam mediated class C $\beta$-lactamase inhibition: competition between reverse acylation and hydrolysis through desulfation. Phys. Chem. Chem. Phys. 2018, 20, 14482-14490.

(10) Krishnan, N. P.; Nguyen, N. Q. Papp-Wallace, K. M.; Bonomo, R. A.; van den Akker, F., Inhibition of Klebsiella beta-Lactamases (SHV-1 and KPC-2) by Avibactam: A Structural Study. Plos One 2015, 10, e0136813. 
(11) Lizana, I.; Delgado, E. J., Molecular insights on the release of avibactam from the acylenzyme complex. Biophys. J. 2019, 116, 1650-1657.

(12) Abboud, M. I., Damblon, C., Brem, J., Smargiasso, N., Mercuri, P., Gilbert, B., Rydzik, A. M., Claridge, T. D. W., Schofield, C. J., Frere, J. M., Interaction of Avibactam with Class B Metallo- $\beta$-Lactamases. Antimicrob. Agents Chemother. 2016, 60, 5655-5662.

(13) Lohans, C. T., Brem, J., Schofield, C. J., New Delhi Metallo- $\beta$-Lactamase 1 Catalyzes Avibactam and Aztreonam Hydrolysis. Antimicrob. Agents Chemother. 2017, 61, e01224-17.

(14) Lomovskaya, O.; Sun, D.; Rubio-Aparicia, D.; Nelson, K.; Tsivkovski, R.; Griffith, D. C.; Dudley, M. N., Vaborbactam: Spectrum of Beta- Lactamase Inhibition and Impact of Resistance Mechanisms on Activity in Enterobacteriaceae. Antimicrob. Agents Chemother. 2017, 61, e01443-17.

(15) Shields, R. K.; McCreary, E. K.; Marini, R. V.; Kline, E. G.; Jones, C. E.; Hao, B.; Chen, L.; Kreiswirth, B. N.; Doi, Y.; Clancy, C. J.; Nguyen M. H., Early Experience With Meropenem-Vaborbactam for Treatment of Carbapenem-resistant Enterobacteriaceae Infections. Clin. Infect. Dis. 2020, 70, 1265-1270.

(16) Kaye, K. S.; Bhowmick, T.; Metallidis, S.; Bleasdale, S. C.; Sagan, O. S.; Stus, V.; Vazquez, J.; zaitsev, V.; Bidair, M.; Chorvat, E.; Dragoescu, P. O.; Fedosiuk, E.; Horcajada, J. P.; Murta, C.; Sarychev, Y.; Stoe, V.; Morgan, E.; Fusaro, K.; Griffith, D.; Lomovskaya, O.; Alexander, E. L.; Loutit, J.; Dudley, M. N.; Giamarellos-Bourboulis, E. J., Effect of Meropenem-Vaborbactam vs Piperacillin-Tazobactam on Clinical Cure or Improvement and Microbial Eradication in Complicated Urinary Tract Infection: The TANGO I Randomized Clinical Trial. JAMA, 2018, 319, 788-799.

(17) Tsivkovski, R.; Lomovskaya, O., Biochemical Activity of Vaborbactam. Antimicrob. Agents Chemother. 2020, 64, e01935-19 
(18) Shields, R. K.; Potoski, B. A.; Haidar, G.; Hao, B.; Doi, Y.; Chen, L.; Press, E. G.; Kreiswirth, B. N.; Clancy, C. J.; Nguyen, M. H., Clinical Outcomes, Drug Toxicity, and Emergence of Ceftazidime-Avibactam Resistance Among Patients Treated for CarbapenemResistant Enterobacteriaceae Infections. Clin. Infect. Dis. 2016, 63, 1615-1618.

(19) Shields, R. K.; Chen, L.; Cheng, S.; Chavda, K. D.; Press, E. G.; Snyder, A.; Pandeyn R.;

Doi, Y.; Kreiswirth, B. N.; Ngyuen, M. H.; Clancy, C. J., Emergence of Ceftazidime-Avibactam

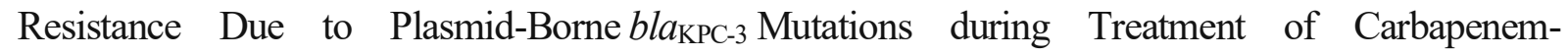
Resistant Klebsiella pneumoniae Infections. Antimicrob. Agents Chemother. 2017, 61:e02097-16. (20) Giddins, M. J.; Macesic, N.; Annavajhala, M. K.; Stump, S.; Khan, S.; McConville, T. H.; Mehta, M.; Gomez-Simmonds, A.; Uhlemann, A. C., Successive Emergence of CeftazidimeAvibactam Resistance through Distinct Genomic Adaptations in bla $\mathrm{KPC}-2_{2}$-Harboring Klebsiella pneumoniae Sequence Type 307 Isolates. Antimicrob. Agents Chemother. 2018, 62, e0210117.

(21) Compain, F.; Arthur, M., Impaired Inhibition by Avibactam and Resistance to the CeftazidimeAvibactam Combination Due to the $\mathrm{D}^{179} \mathrm{Y}$ Substitution in the KPC-2 $\beta$-Lactamase. Antimicrob. Agents Chemother. 2017, 61, e00451-17.

(22) Tsivkovski, R.; Lomovskaya, O., Potency of Vaborbactam is Less Affected than Avibactam in Strains Producing KPC-2 Mutations that Confer Resistance to Ceftazidime-Avibactam. Antimicrob. Agents Chemother. 2020, 64, e01936-19.

(23) Levy, N.; Bruneau, J. M.; Le Rouzic, E.; Bonnard, D.; Le Strat, F.; Caravano, A.; Chevreuil, F.; Barbion, J.; Chasset, S.; Ledoussal, B.; Moreau, F.; Ruff, M., Structural basis for E. coli penicillin binding protein (PBP) 2 inhibition, a platform for drug design. J. Med. Chem. 2019, 62, 4742-4754.

(24) Papp-Wallace, K. M.; Nguyen, N. Q.; Jacobs, M. R.; Bethel, C. R.; Barnes, M. D.; Kumar, V.; Bajaksouzian, S.; Rudin, S. D.; Rather, P. N.; Bhavsar, S.; Ravikumar, T.; Deshpande, P. 
K.; Patil, V.; Yeole, R.; Bhagwat, S. S.; Patel, M. V.; van den Akker, F.; Bonomo, R. A., Strategic approaches to overcome resistance against Gram-negative pathogens using betaLactamase inhibitors and beta-lactam enhancers: activity of three novel diazabicyclooctanes WCK 5153, zidebactam (WCK 5107), and WCK 4234. J. Med. Chem. 2018, 61, 4067-4086. (25) Xiong, H.; Chen, B.; Durand-Réville, T. F.; Joubran, C.; Alelyunas, Y. W.; Wu, D.; Huynh, H., Enantioselective Synthesis and Profiling of Two Novel Diazabicyclooctanone $\beta$ Lactamase Inhibitors. ACS Med. Chem. Lett. 2014, 5 , 1143-1147.

(26) Durand-Réville, T. F.; Guler, S.; Comita-Prevoir, J.; Chen, B.; Bifulco, N.; Huynh, H.; Lahiri, S.; Shapiro, A. B.; McLeod, S. M.; Carter, N. M.; Moussa, S. H.; Velez-Vega, C.; Olivier, N. B.; McLaughlin, R.; Gao, N.; Thresher, J.; Palmer, T.; Andrews, B.; Giacobbe, R. A.; Newman, J. V.; Ehmann, D. E.; de Jonge, B.; O'Donnell, J.; Mueller, J. P.; Tommasi, R. A.; Miller, A. A., ETX2514 is a broad-spectrum $\beta$-lactamase inhibitor for the treatment of drugresistant Gram-negative bacteria including Acinetobacter baumannii. Nat. Microbiol. 2017, 2, 17104.

(27) Ball, M.; Boyd, A.; Ensor, G. J.; Evans, M.; Golden, M.; Linke, S. R.; Milne, D.; Murphy, R.; Telford, A.; Kalyan, Y.; Lawton, G. R.; Racha, S.; Ronsheim, M.; Zhou, S. H., Development of a Manufacturing Route to Avibactam, a beta-Lactamase Inhibitor. Org. Process. Res. Dev. 2016, 20, 1799-1805.

(28) Blizzard, T. A.; Chen, H.; Kim, S.; Wu, J.; Bodner, R.; Gude, C.; Imbriglio, J.; Young, K.; Park, Y. W.; Ogawa, A.; Raghoobar, S.; Hairston, N.; Painter, R. E.; Wisniewski, D.; Scapin, G.; Fitzgerald, P.; Sharma, N.; Lu, J.; Ha, S.; Hermes, J.; Hammond, M. L., Discovery of MK-7655, a beta-lactamase inhibitor for combination with Primaxin (R). Bioorg. Med. Chem. Lett. 2014, 24, 780-785.

(29) Mangion, I. K.; Ruck, R. T.; Rivera, N.; Huffman, M. A.; Shevlin, M., A Concise Synthesis of a beta-Lactamase Inhibitor. Org. Lett. 2011, 13, 5480-5483. 
(30) Miller, S. P.; Zhong, Y. L.; Liu, Z. J.; Simeone, M.; Yasuda, N.; Limanto, J.; Chen, Z.; Lynch, J.; Capodanno, V., Practical and Cost-Effective Manufacturing Route for the Synthesis of a beta-Lactamase Inhibitor. Org. Lett. 2014, 16 , 174-177.

(31) Yang, S. W.; Xin, L. H.; Smith, E.; Pan, J. P.; Sprague, V.; Su, J., Synthesis of bicyclic beta-lactamase inhibitor relabactam derivatives from a relabactam intermediate. Tetrahedron Lett. 2017, 58, 2838-2841.

(32) Edoo, Z.; Iannazzo, L.; Compain, F.; Li de la Sierra Gallay, I.; van Tilbeurgh, H.; Fonvielle, M.; Bouchet, F.; Le Run, E.; Mainardi, J. L.; Arthur, M.; Etheve-Quelquejeu, M.; Hugonnet, J. E., Synthesis of Avibactam Derivatives and Activity on beta-Lactamases and Peptidoglycan Biosynthesis Enzymes of Mycobacteria. Chem.- Eur. J. 2018, 24, 8081-8086.

(33) Kolb, H. C.; Finn, M. G.; Sharpless, K. B., Click chemistry: diverse chemical function from a few good reactions. Angew. Chem. Int. Ed. 2001, 40, 2004-2021.

(34) Ohnmacht, S.; Nava, P.; West, R.; Parker, R.; Atkinson, J., Inhibition of oxidative metabolism of tocopherols with omega-N-heterocyclic derivatives of vitamin E. Bioorg. Med. Chem. 2008, 16, 7631-7638.

(35) Bush, K.; Bradford, P. A., Interplay between beta-lactamases and new beta-lactamase inhibitors. Nat. Rev. Microbiol. 2019, 17, 459-460.

(36) Lahiri, S. D.; Mangani, S.; Durand-Reville, T.; Benvenuti, M.; De Luca, F.; Sanyal, G.; Docquier, J. D., Structural insight into potent broad-spectrum inhibition with reversible recyclization mechanism: avibactam in complex with CTX-M-15 and Pseudomonas aeruginosa AmpC beta-lactamases. Antimicrob. Agents Chemother. 2013, 57, 2496-2505.

(37) King, D. T.; King, A. M.; Lal, S. M.; Wright, G. D.; Strynadka, N. C. J., Molecular Mechanism of Avibactam-Mediated beta-Lactamase Inhibition. ACS Infect. Dis. 2015, 1, 175184. 
(38) Ourghanlian, C.; Soroka, D.; Arthur, M., Inhibition by avibactam and clavulanate of the $\beta$-lactamases KPC-2 and CTX-M-15 harboring the substitution $\mathrm{N}^{132} \mathrm{G}$ in the conserved motif SDN. Antimicrob. Agents Chemother. 2017, 61, e02510-16.

(39) Hugonnet, J. E.; Blanchard, J. S., Irreversible inhibition of the Mycobacterium tuberculosis beta-lactamase by clavulanate. Biochemistry 2007, 46, 11998-20004.

(40) Quotadamo, A.; Linciano, P.; Davoli, P.; Tondi, D.; Costi, M. M.; Venturelli, A., An Improved Synthesis of CENTA, a Chromogenic Substrate for $\beta$-Lactamases. Synlett 2016, 27, 2447-2450.

(41) Clinical and Laboratory Standards Institute, W., PA., Methods for dilution susceptibility tests for bacteria that grow aerobically; approved standard. Clin Lab Stand Inst M7-A8, 10th ed. 2015.

\section{TABLE OF CONTENTS GRAPHIC}
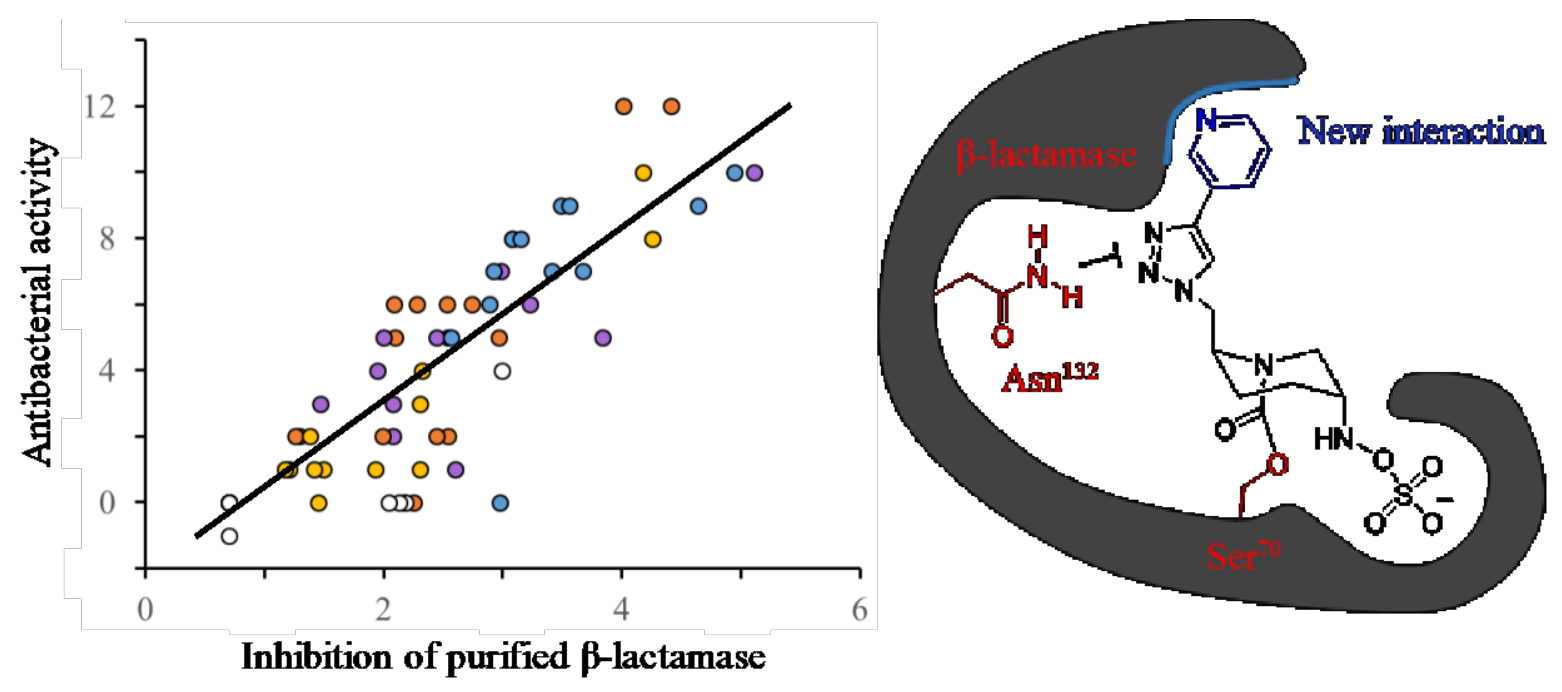


\section{Table of Contents graphic.}
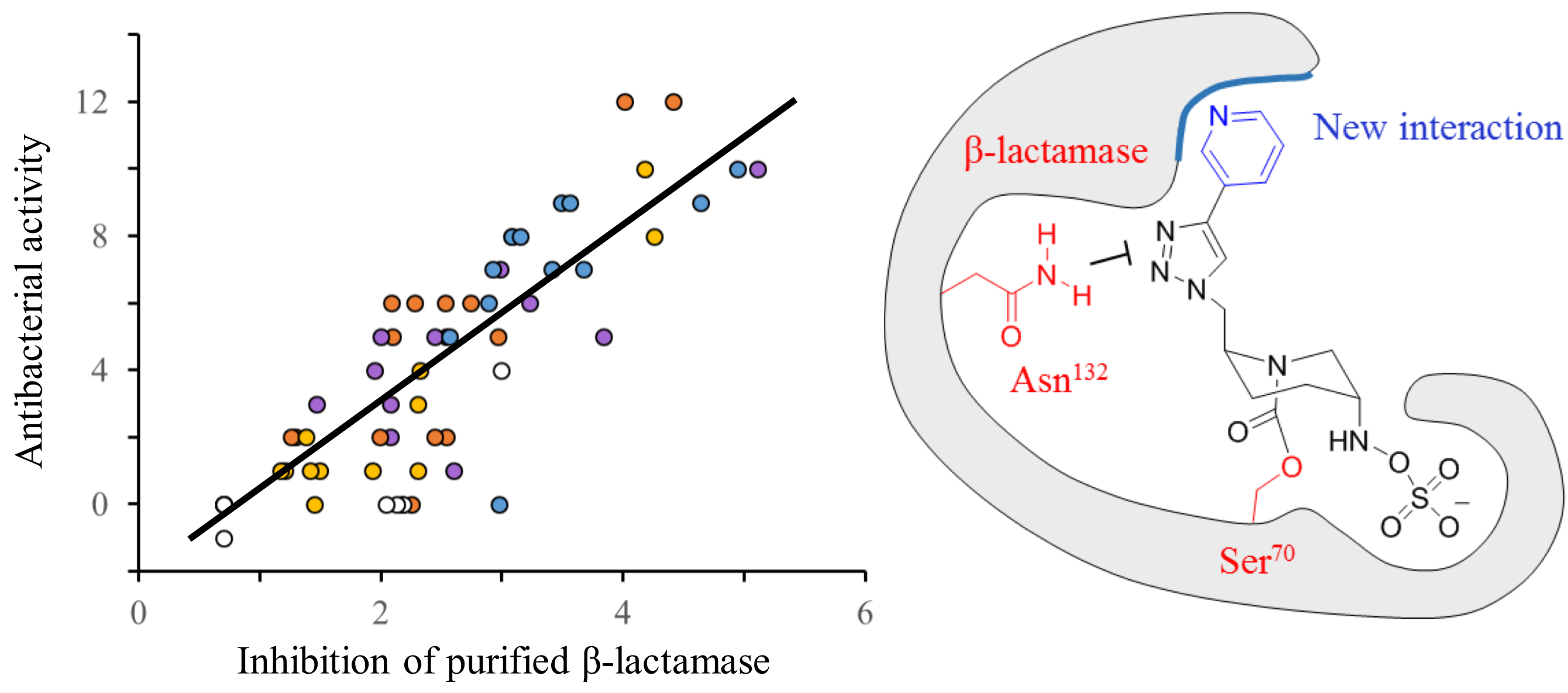